The Stratigraphic Section

in the Vicinity of

Eureka, Nevada

GEOLOGICAL SURVEY PROFESSIONAL PAPER 276

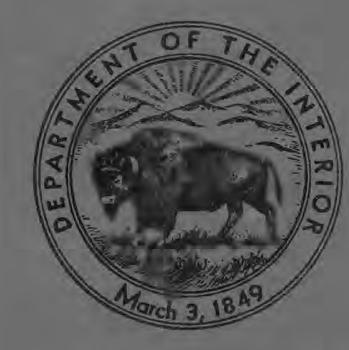




\section{The Stratigraphic Section}

in the Vicinity of

Eureka, Nevada

By T. B. NOLAN, C. W. MERRIAM, and J. S. WILLIAMS

GEOLOGICAL SURVEY PROFESIONAL PAPER 276

Revision of the pre-Tertiary stratigraphy

of east-central Nevada

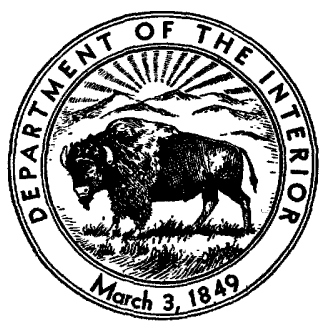

UNITED STATES GOVERNMENT PRINTING OFFICE, WASHINGTON : 1956 


\section{UNITED STATES DEPARTMENT OF THE INTERIOR}

Douglas McKay, Secretary

\section{GEOLOGICAL SURVEY}

W. E. Wrather, Director 


\section{CONTENTS}

Abstract

Introduction

Acknowledgments

Structural setting

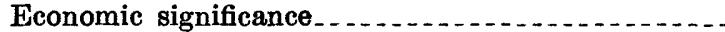

Cambrian system

Prospect Mountain quartzite......

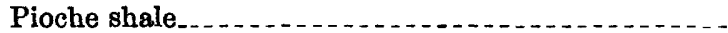

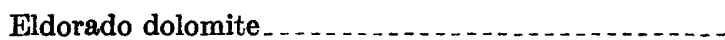

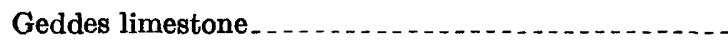

Secret Canyon shale.....................

Lower shale member. . . . . . . . . . . .

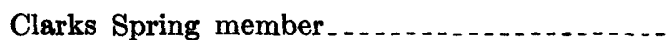

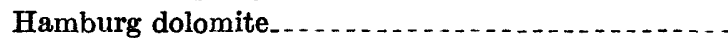

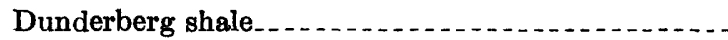

Windfall formation

Catlin member.

Bullwhacker member...........................

Ordovician system.

Eastern facieg

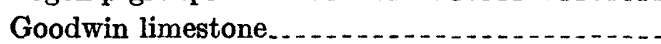

Ninemile formation. . . . . . . . . . . . . .

Antelope Valley limestone.......................

Eureka quartzite.

Hanson Creek formation....................

Western facies.

Vinini formation
Pogonip group..........

\begin{tabular}{|c|c|c|}
\hline Page & & 0 \\
\hline 1 & Silurian system.- & 36 \\
\hline 2 & Roberts Mountains formation & 36 \\
\hline 3 & Lone Mountain dolomite........ & 37 \\
\hline 3 & Devonian system & 40 \\
\hline 5 & Nevada formation & 40 \\
\hline 5 & Beacon Peak dolomite member & 42 \\
\hline 6 & Oxyoke Canyon sandstone member & 43 \\
\hline 7 & tain dolomite member & 43 \\
\hline 9 & Woodpecker limestone member. & 44 \\
\hline 11 & Bay State dolomite member & 45 \\
\hline 12 & one & 48 \\
\hline 13 & er. & 49 \\
\hline 10 & member..... & 49 \\
\hline 14 & Devonian and Mississippian systems & 52 \\
\hline 16 & Pilot shale. & 52 \\
\hline 18 & ems & 54 \\
\hline 19 & 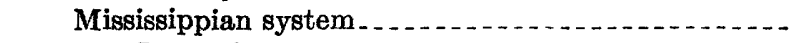 & 54 \\
\hline 20 & 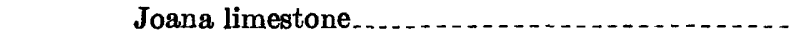 & 54 \\
\hline 21 & Upper Mississippian formations & 56 \\
\hline 23 & n shale & 59 \\
\hline 23 & Peak formation & 60 \\
\hline 23 & ystem & 61 \\
\hline 25 & 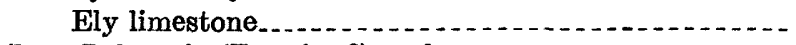 & 61 \\
\hline 27 & Late Paleozoic (Permian?) rocks & 63 \\
\hline 28 & Carbon Ridge formation & 64 \\
\hline 28 & formation & 67 \\
\hline 29 & Cretaceous system & 68 \\
\hline 32 & Newark Canyon formation & 68 \\
\hline 34 & References cited & 70 \\
\hline 34 & Index.-. & 73 \\
\hline
\end{tabular}

\section{ILLUSTRATIONS}

Prate 1. Map of central Nevada, showing location of places referred to in the text............. In pret

2. Stratigraphic sections of Lower and Middle Paleozoic rocks in the vicinity of Eureka, Nev.......... In prcket

Frgure 1. Sections of Carboniferous sedimentary rocks at Tyrone Gap, Eureka; and Diamond Peak

2. Sketch of geology between Ruby Hill and Adams Hill: 



\title{
THE STRATIGRAPHIC SECTION IN THE VICINITY OF EUREKA, NEV.
}

\author{
By T. B. Nolan, G. W. Merriam, and J. S. Williams
}

\section{ABSTRACT}

The stratigraphic section at Eureka, Nev., as defined by King, Hague, and Walcott, has been used as a standard in the central Great Basin for more than 75 years. Detailed mapping, which has led to a better understanding of the geologic structure of this area, together with continued paleontologic study has modified some of the earlier conclusions about the section. Revisions and changes in nomenclature and age assignments consequent on this recent work are here presented.

These new conclusions concerning the stratigraphy are in accord with the concept of two major elements in the geologic structure of central Nevada: one is the development, at least twice during Paleozoic time, of linear swells or positive areas that caused marked lateral changes in sedimentation in the seaways and locally resulted in nondeposition and even erosion of earlier deposited sediments. The other is the existence of many thrust faults of large displacement that have brought notably different sedimentary facies into juxtaposition with one another. An understanding of the revised stratigraphy, and the structural setting in which the sedimentary rocks occur, probably is helpful in exploration for both metalliferous deposits and petroleum accumulations.

The Cambrian sedimentary rocks have been divided into 8 formations, 2 of which are made up of 2 members each. They have a total thickness of about 7,400 feet and include strata assigned to the Lower, Middle, and Upper Cambrian. The increase in the number of formations from the 5 units originally described at Eureka has been accompanied by a more precise assignment of the present and earlier fossil collections to the appropriate stratigraphic units and hence by a more accurate determination of faunal sequences.

The following Cambrian formations are distinguished: the Prospect Mountain quartzite and the Pioche shale are the Early Cambrian formations; the Eldorado dolomite, the Geddes limestone, and the Secret Canyon shale (with a lower shale member and an upper Clarks Spring member) are of Middle Cambrian age; the Hamburg dolomite is Middle Cambrian at the base and probably Late Cambrian above; and the Dunderberg shale and the Windfall formation (with a lower Catlin member and an upper Bullwhacker member) are of Late Cambrian age.

In contrast with the rocks of Cambrian age, of which only one sequence of facies was recognized, there are two very different facies or Ordovician rocks in the Eureka district; they have been brought together by a major thrust-the Roberts Mountains thrust. The two are thought to have been deposited in separate seas which developed through the formation of a positive area or swell early in the Ordovician and acted as a barrier between the seaways.

The eastern sequence, which rests with apparent conformity on the Cambrian strata, is composed of five formations with a total thickness of more than 2,500 feet. Three of these, the Goodwin limestone, Ninemile formation, and Antelope Valley limestone, make up the Pogonip group of Early and Middle Ordovician age. They are overlain unconformably by the
Eureka quartzite, of probable Middle Ordovician age, and it, in turn, is unconformably overlain by the Hanson Creek formation of Late Ordovician age. The Hanson Creek formation is composed of dolomite to the east, but is limestone in the western sections. Except for the Eureka quartzite this eastern sequence is composed almost exclusively of limestone or dolomite.

The western Ordovician sequence, in contrast, contains only a small amount of carbonate rocks; it is made up chiefly of bedded chert, quartzite, and graptolite-bearing shales. These beds are included in the Vinini formation, and are about eqvivalent in age to the Ninemile and Antelope Valley formations of the eastern sequence.

Silurian sedimentary rocks are known with assurance only in an eastern facies; their absence in western-facies sections may be due either to erosion or nondeposition. In the Eureka region, however, there is considerable variation between the rections that are exposed. To the west and north, the Roberts Mo'ıntains formation, as much as 1,900 feet in thickness, rests on the Hanson Creek formation. It contains a Middle Silurian fauna and is succeeded conformably in this part of the area by the Lone Mountain dolomite, which reaches a thickness of 2,200 feet. The Lone Mountain just west of Eureka contains, near the top, an Upper Silurian fauna. In the sections east of Fureka, the Roberts Mountains formation appears to be absent, and the interval between the Hanson Creek formation and st"ata of Devonian age is occupied by thick-bedded poorly fossi iferous dolomites that have been included within the Lone Mountain dolomite.

Rocks of Devonian age are more widely distributed than those of any of the other Paleozoic systems; individual section ' range from 3,000 to about 5,000 feet in thickness. All the sections exposed in the Eureka region belong to the eastern faries, as beds of this age are not known in the plate above the Foberts Mountains thrust. An unconformity that probably is widespread separates these rocks from the Lone Mountain dolomite below; the contact with sedimentary rocks of Mississippian age above is conformable and is regarded as falling within a sequence of black calcareous shales. The thinner sections to the north and northeast appear to be not the result of erosion therefore, but to be caused by either nondeposition or by a slower rate of deposition in this direction.

Three formations have been recognized as of Devonian age. The lowest of these is the Nevada formation. Over muck of the region five members may be mapped; they are, in ascending order: the Beacon Peak dolomite member, the Oxyoke Canyon sandstone member, the Sentinel Mountain dolomite memk or, the Woodpecker limestone member, and the Bay State dolomite member. As is true of the carbonate rocks of late Ordovician and Silurian age, the older carbonate units of the Nevada formation are relatively richer in limestone westward; this change probably reflects the proximity of a shoreline in that direction.

Five faunal zones have been recognized in the Nevada formation: two are of early Devonian age; the upper three are assigned to the Middle Devonian. 
The Devils Gate limestone overlies the Nevada formation. Through part of the area it may be subdivided into a lower Meister member and an upper Hayes Canyon member. The Devils Gate limestone decreases in thickness notably to the north and east. Of its six included faunal zones, three are regarded as of Middle Devonian age and three of Late Devonian age.

The uppermost formation is the Pilot shale. It contains an Upper Devonian conodont fauna in its lower part; the upper part probably is of early Mississippian age. The Pilot shale is the basal part of the "White Pine shale" as defined by Hague at Eureka.

No sedimentary rocks of Carboniferous age have been recognized in the thrust block containing the western sequence; they are abundant, however, in the eastern sequence. Here they show a very wide range in lithologic character and in thickness. This range probably is due chiefly to the proximity of a land mass or swell that was situated not far to the west and that appears to have been subject to recurrent uplift throughout much of Carboniferous time. The maximum thickness of Carboniferous strata is in excess of 9,000 feet.

The oldest unit wholly within the Carboniferous is the Joana limestone, which overlies the Pilot shale conformably. It contains a lower Mississippian or Madison fauna, and is overlain unconformably by a thick section of variable lithologic character that is largely, if not wholly, of late Mississippian age. Black shales predominate in the lower part of this sequence, an alternation of sandstones, conglomerates, limestones, and shales in the upper part. - Locally the two units may be separately mapped as the Chainman shale and the Diamond Peak formation; over much of the region, however, the zone of intergradation is so thick that the sequence has been mapped as upper Mississippian undifferentiated.

The youngest Carboniferous formation is the Ely limestone. In the Diamond Range it has a maximum thickness of about 1,500 feet, but south of Eureka this limestone, and the Diamond Peak formation locally, has been completely removed by prePermian erosion. The Ely limestone which contains a fauna of early Pennsylvanian age, rests conformably on the Chainman and Diamond Peak sequence.

Rocks of Permian(?) age are found in both the eastern and western sequences. The two sections are, however, quite unlike in lithologic character and in thickness.

The eastern sequence of Permian(?) age has been named the Carbon Ridge formation. It is composed of sandy or silty limestones, is dominantly thin bedded, has a maximum thickness of 1,750 feet, and rests with marked unconformity on the underlying Carboniferous rocks. In places both the Ely limestone and the Diamond Peak formation had been removed by erosion before the Carbon Ridge formation was deposited. The formation is abundantly fossiliferous and contains faunas of Wolfcamp and probable Leonard age.

The western sequence is also unconformable on older rocks. It rests, however, upon folded beds of the Vinini formation which, moreover, may have undergone minor thrust faulting before the Permian(?) strata, which are described as the Garden Valley formation, were laid down. The positive area, or swell, which had contributed so much material to the Eureka Carboniferous section, ceased rising in the area now underlain by the Garden Valley formation. There were, however, emergent areas, for in the Garden Valley formation are two lithologic members containing significant thicknesses of coarse conglomerates with some interbedded sandstone and shale, in addition to a basal limestone member and an uppermost red-bed unit. The maximum thickness measured is about 3,000 feet; this section, however, cortains at least one marked unconformity. The basal limestone member contains a fauna of probable Wolfcamp age. The three upper members contain scant fosfils; some poorly preserved pelecypods in the red beds are somowhat suggestive of early Mesozoic forms.

The youngest consolidated sedimentary formation recognized in the Eureka region is the Newark Canyon formation of Early Cretaceous age. It is a heterogeneous unit, approximately 1,800 feet thick, composed of shales, quartzites, conglomerates, and limestones that probably are all of fresh-water orisin. It rests with angular unconformity on the older rocks, in places lying on rocks as old as middle Paleozoic. In many places the hads are fossiliferous, and a fairly extensive fauna and flora of gastropods, plants, and fish has been collected. These beds are the sisurce of the freshwater "Carboniferous" fauna described by Harue and Walcott.

\section{INTRODUCTION}

The stratigraphic section described by King (1878), Hague $(1883,1892)$ and Walcott (1884) from the region in east-central Nevada centering around Eureka has long been used as a standard for the central Great Basin. Not only have the thicknesses and variations in lithologic character exposed there been used for comparative purposes in adjoining areas, but the individual formation names have been extended widely. Interest in, and reference to, the section, moreover, has increased greatly in the past 10 years or so, in Fart because of the increased exploratory activity for extensions of the mineral deposits that have made the area so well known, but primarily because of an active and extensive search for possible accumulations of petroleum.

The work by King, Hague, and Walcntt, done more than 60 years ago, established for the Great Basin new standards of detailed geologic mapping and of stratigraphic and paleontologic study. Relatively little review of the early work has been undertaken, although Walcott himself (1923), Kirk (1933), Wr seler and Lemmon (1939), Merriam and Anderson (1942), Sharp (1942), Hintze and Webb (1950), and Humphrey (1956) have proposed changes as a result of more detailed study of either restricted portions of the section or of particular areas. Recent work, howerer, appears to show the need for a more complete revision of the section, taking into account modern cc ncepts both of the structural history of the Great Basin province and of paleontologic correlations. An increase in the number of detailed topographic maps and of aerial photographs have made such a revision much more easily accomplished.

The suggested revisions presented in this paper are based on field work in the vicinity of Eureka (pl. 1) undertaken by the writers and their associates at intervals during the past 22 years. We write with some hesitation as we are aware of the hazards of premature generalizations in this structurally complex area, but the current interest in the geology of the Eureka district 
will, we hope, bring out criticism or comment on these results that will speed the process of a better understanding of the stratigraphy of this part of the Great Basin. Our work does not precisely coincide with the area mapped by Hague, because we include areas outside his and we did not review some areas included in Hague's map. We have done detailed mapping, mostly for economic purposes, of the Eureka mining district quadrangle, and in parts of the Garden Valley, Mineral Hill, Eureka, and Pinto Summit 15-minute quadrangles, as well as on Lone Mountain and in parts of Antelope Valley west of Eureka. Reconnaissance mapping and exploration, as well as measurement of sections, has been done in many intervening areas and also to the northwest as far as Cortez. In general, therefore, the area covered by this paper includes an area slightly larger than that included in Hague's map.

\section{ACKNOWLEDGMENTS}

We have benefited over the years by assistance from many sources. The list of field assistants includes Alan Broderick, 1938; John S. Shelton, 1939; D. T. Griggs, 1939 and 1940 ; J. V. N. Dorr 2d, 1940; Robert Liscomb, 1949; R. M. Osterstock, 1950; T. R. Slodowski, 1951; Warren Bart, 1952, and John Stone, 1953-54. Officials of mining and petroleum companies have been uniformly cooperative: we are deeply indebted for many forms of assistance especially to George W. Mitchell and Thayer Lindsley of the Eureka Corp.; J. A. Hogle, of the Diamond-Eureka mine; and Olin Lane, of the Continental Oil Co. In the field William Sharp, of the Eureka Corp. and later a consultant to the DiamondEureka mine, was a continuing source of help because of his detailed and accurate knowledge of this part of Nevada. Other acknowledgments are due also to Harry Eather and Jack Brozo, of the Eureka Corp.; Sherman Hinckley, of the Diamond mine; Tony Frank and John Cardinelli, of the Croesus mine and later of the zinc properties on Lone Mountain; William $\mathbf{R}$. Moran and John Hazzard, of the Union Oil Co.; John Wiese of the Richfield Oil Co.; and J. G. Anderson and John Huber, of the Continental Oil Co.

In the office Miss Jane Wallace, of the Geological Survey, not only has checked the references and been largely responsible for the preparation of the illustrations, but also has cheerfully assumed the onerous duty of resolving the numerous problems that needed solution in transmittal of our draft report for editing and printing.

Finally, we are indebted for paleontologic assistance, both in the field and the office, to Josiah Bridge, A. R. Palmer, Preston Cloud, and G. A. Cooper on Cambrian and Ordovician faunas; to Helen Duncan, Lloyd Henbest, Mackenzie Gordon, Jr., I. G. Sohn, and W. H. Hass, on the Carboniferous faunas that were collected; and to F. S. MacNeil, on the Cretaceous fauna. Many of these paleontologists, as well as some of our field assistants, might well have been included as joint authors of this paper, so significant have been their contributions.

\section{STRUCTURAL SETTING}

Any general review of the stratigraphy of a goodsized area in this part of the Great Basin soon reveals the virtual impossibility of wholly separating consideration of the stratigraphic column from a parallel consideration of the geologic structure of this re?ion. While this is a truism that perhaps applies to any geologic province in greater or lesser degree, our work has shown that in the Eureka district interpretation of the sedimentary sequences that may be observed at any particular point requires a rather comprehensive knowledge of the structural history of the province as a whole.

Two elements of the structural history have been of especial importance in their effect on the stratigriphy of the area. One of these was the formation, at least twice during the Paleozoic, of linear swells or poritive areas; the second is the presence throughout the region of numerous thrust faults of very large displacement which may have formed at various times from the late Paleozoic into the early Tertiary.

The swells or positive areas appear to have been major factors in the formation of markedly different facies of sedimentary deposits of the same age. In part, this variation results from normal changes in sedimentation away from a rising land mass toward the center of the seaway; in part, it results from sedimentation in the two separate troughs which were created by the elevation of the swell above sea level.

Much more field study will be needed to outline precisely the extent and nature of the swells. Our work, however, suggests that there were two that ererted significant influence on the sedimentary record. The earlier of the two appears to have developed in Early or Middle Ordovician time and to have resulted in two seaways in which markedly different sedimentation occurred. It probably was of relatively short duration compared to the second swell, which is believed to have been initiated in Late Devonian time and to have continued active throughout much of the Carboniferous and Permian. This longer history is marked by noteworthy rapid lateral changes in the lithologic character of the sediments, especially in clastic portions of the section, and by several unconformities within the Carboniferous which are angular to the extent that as much as several hundreds of feet of sediments may be cut out within relatively short strike distances. 
The significance of the overthrusting lies in the fact that as a result of it, notably different sedimentary facies have been brought into juxtaposition. Perhaps the most striking of such occurrences is found just north and east of Eureka itself, where shales, cherts, and quartzites of Early and Middle Ordovician age

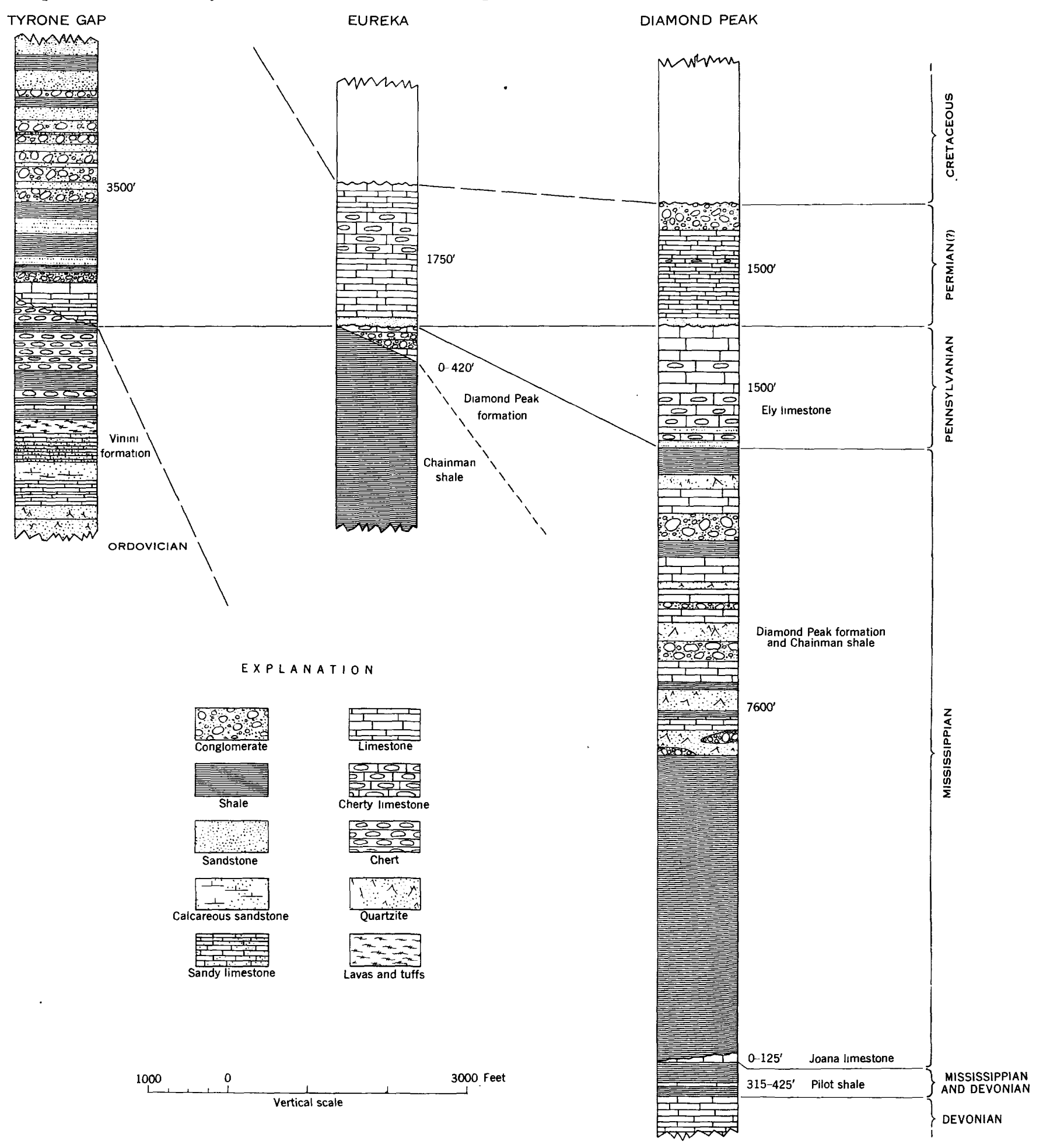


scale thrusting. Figure 1 shows graphically the notable difference in thickness of Carboniferous and Permian rocks at three localities within a 10-mile radius in the vicinity of Eureka, each section being separated from the other by a large thrust fault. The considerable differences between the rocks of Ordovician age above and below the major thrust are indicated by the sections of pre-Carboniferous rocks included in plate 2 . This illustration also shows the less striking, although still pronounced, changes in thickness and lithologic characteristics of these older rocks east of and below the major thrust.

\section{ECONOMIC SIGNIFICANCE}

These conclusions are of some interest both to the metal miner and to the petroleum industry. So far as the metal miner is concerned, projected explorations of deeper favorable horizons for ore deposition must always be undertaken with the realization that projections from surface exposures may prove to be incorrect because of the possibility that facies changes due either to original variations in sedimentation or to thrust faulting may be found. Conversely, these two factors may cause favorable ore zones to be encountered quite unexpectedly.

The petroleum geologist is even more directly affected. Wildcat wells designed to prospect anticlines exposed at the surface or to reach horizons judged to possess desirable physical properties, such as proper porosity or permeability, may well disclose, if the well extends to any considerable depth, that the structural or lithologic features revealed are entirely different from those expected. If our mapping at Eureka is a valid guide, it would seem probable that most wells in the order of 10,000 feet in depth are likely to strike at least one thrust fault with resulting unrelated structure and stratigraphy beneath it. On the other hand, it is not unlikely that this combination of thrusting and facies changes may provide additional opportunities for petroleum accumulation that have thus far apparently been neglected in proposed explorations in the region. The occurrence of a petroliferous zone in which a desirable porosity has been induced by the fracturing caused by a superjacent overthrust that in itself constitutes an impervious seal to the reservoir thus created is by no means an impossibility. Actually, it is probable that such a setting may be more likely to be productive than exploration of potential reservoir horizons in conventional anticlines, because in these reservoir horizons permeability may have been so decreased by the ever-present thrust faulting that productivity is unlikely.

\section{CAMBRIAN SYSTEM}

The Cambrian section at Eureka has been know" and studied since the days of the survey of the 40th parallel (King, 1878); it has been a standard of comperison for many less complete or more recently discovered sections in the Great Basin, both in regard to the formation names that were first used there and the fossil sequences that were first determined in these formations. The section is still of great interest to those concerned with the stratigraphy and faunal history of the Cambrian, since it is one of the relatively few localities in Nevada north of latitude $37^{\circ}$ and west of the Utah boundary having an essentially complete sequence in an environment where the geologic structure is sufficiently well understood to permit determination of both rock and fossil succession.

The correct sequence of fossil faunas is of especial importance in the study of Cambrian rocks in Nevada since the known outcrops of these rocks over the northern three-quarters of the State are both smal and widely scattered. As a consequence, correlstions based on lithologic character alone are unreliable, as facies changes that have occurred in the hidden intervening areas in many places have produced strikingly different sequences in rocks that the fossil record indicates are of identical ages. The total area of outcrop of Cambrian rocks at Eureka, for example, is probably less than 20 square miles. The nearest exposures of Cambrian rocks to Eureka are at Hamilton, 30 miles to the southeast (King, 1878; Hague, 1883, 1892; and Humphrey, 1956); the Ruby Rang?, 50 miles to the northeast (Sharp, 1942); the Antelope Range, 25 miles to the southwest (Merriam, 1956); and Cortez, nearly 50 miles to the northwest (Merriam and Nolan, 1940; James Gilluly, 1947, written communication; Hintze, 1951). At the first two localities mentioned fairly complete sections are found, but at the two westerly ones only higher Cambrian formations have been recognized.

In the current restudy of the Cambrian formations of the Eureka district, we have recognized 10 mappable units, comprising 8 formations, and 4 members, in contrast with the 5 units described by Hague in 1892. This increase results in part from the elevation to formation rank of units such as the Pioche shale and Geddes limestone, which were recognized by the earlier workers as stratigraphically distinct but not thought by them to be sufficiently significant to warrant separate mapping. In part, though, the additional units reflect a more accurate knowledge of the structure of the district, which has permitted concomitantly, a better definition of the stratigraphy. An important byproduct of this increased knowledge has been a more precise assignment of the earlier fossil 
collections to the appropriate stratigraphic units, with a consequent refinement of our knowledge of the faunal sequence.

The section of Cambrian rocks at Eureka does not appear in itself to have been seriously complicated by the superposition of dissimilar facies as a result of major overthrusting. The section has been cut by numerous minor thrusts, however, and three significant thrust slices of Cambrian rocks have been distinguished; these differ only in minor respects in their thickness and lithologic character. However, the minor thrusting may have a spatial, and perhaps a causal, relation to a major thrust that has brought together two very dissimilar facies of Ordovician rocks that originally must have been many miles apart.

The apparent failure of this large thrust to carry with it rocks of Cambrian age raises some interesting questions. It appears at first glance to support the hypothesis advanced by Hague (1892, p. 175-182) that the western border of the Paleozoic geosyncline in which the Cambrian sediments were deposited, was not far west of Eureka. Since the time of Hague's writing, however, fossiliferous Cambrian strata have been found in the Toiyabe and Toquima Ranges (Ferguson, 1924), the Osgood Mountain region (P. E. Hotz, oral communication), and most recently in the vicinity of Mount Lewis (James Gilluly, oral communication). It is clear that a Cambrian seaway did exist for a considerable distance west of Eureka and that great thicknesses of sediments were deposited in it; the failure of Cambrian sedimentary rocks to be present above the thrust must therefore be due to other causes.

These more western Cambrian sections are dominantly clastic, and contrast with the carbonate-rich facies at Eureka; a similar relationship exists between the western clastic, and eastern carbonate, facies of the Ordovician rocks. The relationship between the two Cambrian facies could presumably be either an interfingering one, or be the result of deposition in separate basins. The correct interpretation requires detailed stratigraphic and faunal studies at the few localities at which these Cambrian rocks are exposed; the answers that may be obtained by such detailed work should not only assist in the elucidation of the structural history of the Great Basin but also have a practical bearing on the search for ore deposits and for petroleum.

\section{PROSPECT MOUNTANN QUARTZITE}

\section{GENERAL FEATURES}

The Prospect Mountain quartzite is the oldest formation exposed in the Eureka district. It was named by Hague (1883, p. 254) from exposures on Prospect Peak, the highest summit on Prospect Ridge, a northerly trending ridge that lies west and south of the town of Eureka. The use of Prospect Mountain for the formation, rather than Prospect Peak or P-ospect Ridge, which are the two geographic features defined by Hague, seems never to have been explained by him; but the long use of Prospect Mountain for the formation makes it undesirable to question the nomenclature.

The total area of outcrop of the quartzite is about half a square mile. The formation forms a discontinuous hook-shaped band that extends ncrthward from the west slope of Prospect Peak to the south side of Ruby Hill and then swings southward along the east side of the ridge nearly to the Eureka Tunnel. The discontinuity is due in part to transgression of the outcrop band by the Spring Valley fault which bounds Prospect Ridge on the west but mainly to the fact that the quartzite is restricted to a folded thrust slice that overlies younger Cambrian strata to the east and is itself overridden by thrust masses of your zer Cambrian and Ordovician strata to the west. On the south slope of Ruby Hill, the thrust slice is only a few feet thick.

The formation is composed in large part of fairly well sorted quartzite, the average grain size being about 1 millimeter. On fresh fracture, the rock is white; it weathers to shades of pink, red, or brown. In places, however, shades of gray predominate in both outcrop and float. The weathered surfaces not uncommonly show a faint cross-lamination. Shale interbeds constitute less than 5 percent of the unit and range from a few inches to a few feet in thickness. They are normally micaceous and sandy and appear to be more numerous in the lower part of the sequence. An even smaller proportion of the total thickness is made up of pebbly or conglomeratic beds; one such $k$ id was found on the ridgeline south of Cave Canyon at an elevation of about 8,675 feet. A rather distinctive concretionary bed, the individual concretions being an inch or so in diameter and only a quarter of an inch thick, was recognized at several places north of Cave Caryon.

In gener al, the Prospect Mountain quar'zite is poorly exposed. Because of its position between two thrusts, it is thoroughly fractured, and forms smooth, rounded slopes underlain by small joint blocks, which range from an inch to about six inches across. The smooth slopes are further distinguished by their sparse and scattered vegetation. Outcrops in which strikes and dips can be determined are rare. Probably the best sequence of exposures to be seen is in the bottom of Cave Canyon, although the thickness of beds present here is probably somewhat less than in the steep gulch further south.

There are two other quartzitic units with which the Prospect Mountain quartzite might be confused-the Ordovician Eureka quartzite, and quartzite of the Devonian Oxyoke Canyon sandstone member of the Nevada formation. The Prospect Mountain has a 
higher content of argillaceous and ferruginous material in the cement than the Eureka, and is somewhat more variable in grain size. Perhaps the most useful distinction in the field, however, lies in the differences in weathering. The Prospect Mountain characteristically forms small angular blocks that are brown to pink in color, and the Eureka forms much larger rounded blocks ( 1 to 2 feet or more in diameter) that are commonly a rather brilliant white. The quartzites in the Oxyoke Canyon member can normally be distingiushed easily by their content of dolomite, and by the widespread large-scale crossbedding.

The total thickness of the Prospect Mountain quartzite at Eureka is unknown, as the base is nowhere exposed. We have, like Hague (1892, p. 102), selected as the top of the formation the base of a sequence of shale, sandstone, and limestone that is here correlated with the Pioche formation of the Pioche district (Walcott, 1908a, p. 9-12). In his earlier report on the district, however, Hague (1883, p. 256-257) seems to have included the Pioche shale in the Prospect Mountain quartzite. Walcott (1884, p. 284-285) also seems to have made this correlation. Wheeler and Lemmon (1939, p. 17-18), like Sharp (1947, p. 1), included these beds in the Prospect Mountain quartzite, although Sharp distinguished the Pioche shale as an upper subdivision. Hague $(1892$, p. 35) reports a thickness of 1,500 feet on Prospect Peak; Wheeler and Lemmon (1939, p. 17) measured 1,660 feet along a section a quarter of a mile north of Prospect Peak; their section, however, included 200 feet of beds assigned by us to the Pioche. More precise measurements of the thickness of the Prospect Mountain quartzite are not warranted because of the poor exposures, variable dips, and intense fracturing over the greater part of the outcrop area.

\section{AGE AND CORRELATION}

No determinable fossils have been found in the Prospect Mountain quartzite as here defined. The apparrently conformable contact between the quartzite and the overlying fossiliferous Pioche shale has, however, caused general acceptance of the assignment of the Prospect Mountain to the Lower Cambrian. A similar quartzite is found widely in this stratigraphic position in eastern and southern Nevada and western Utah; locally the unit has been called the Tintic quartzite or Stirling quartzite, although in central and eastern Nevada the name Prospect Mountain quartzite is used. There are no other exposures of the unit, so far as we are aware, within about 30 miles of Eureka.

\section{PIOCHE SHATE}

\section{GENERAL FEATURES}

A thin formation composed of micaceous shale, sandstone, and limestone can be distinguished above the Prospect Mountain quartzite; it has been mapped as the Pioche shale. It lies between the Prospect Mountain quartzite and the Eldorado dolomite where the two are in their normal stratigraphic position. Hague (1892, p. 41-42) recognized the presence of these beds which, he wrote,

may be regarded as transition beds between [the quartzite] and the "Prospect Mountain" [Eldorado] limestone . . . . Along the east side of Prospect Peak, near the summit of the ridge, there may be traced for over a mile a red arenaceous and calcareous shale, ... This arenaceous shale may be taken at 100 feet in thickness, and from the organic remains which it carriss and from its paleontological and geological importance has been designated the Olenellus shale.

Earlier, however, both Hague (1883, p. 254) and Walcott $(1884$, p. 284) included these beds in the Prospect Mountain quartzite. Wheeler and Lermon (1939, p. 18) also recognized the unit and regarded it as "at least partially equivalent to the Pioche shale of the Pioche district." Because they found the beds for only a short distance on Prospect Peak, however, they did not regard the unit as of formational rank. Both Sharp (1947, p. 1), and the Eastern Nevada Geological Association (Easton and others, 1953, p. 146-7), report the presence of the Pioche shale in the district, the former as a subdivision of the Pronect Mountain quartzite.

The Pioche shale has a limited distribution on the surface, being found in a narrow, discontinuous band that extends from the vicinity of the Prospect Mountain Tunnel near the west base of Prospect Ridge southward to a short distance southeast of Prospect Peak. It has also been recognized in a few places on the lower levels of the Richmond-Eureka mine on Ruby Hill. Normally in the mine, however, the formation is missing at the contact between the Prospect Mountain quartzite and the Eldorado dolomite, as a result of elimination of the beds along a thrust fault that appears to be fairly persistent at this horizon. R. T. Walker ${ }^{1}$ in a report on the Richmond-Eureka mine distinguished these underground exposures of the formation as the "Thin quartzite." He considered that it occurred between upper and lower members of the Eldorado dolomite, rather than at the base of the Eldorado; we believe, though, that this relationship can be explsined by faulting. Hague (1892, p. 38) also reported shale from "all the deep mines on Ruby Hill." He tentatively correlated these occurrences with his "Mountain shale," a unit he believed to fall within the Eldorado. Our mapping, however, has shown that most of Hague's "Mountain shale" exposures belong either to the Secret Canyon shale or to the Dunderberg shale and are in

${ }^{1}$ Walker, R. T., 1923, The Richmond-Eureka"Mine: Private report prepsred for U. S. Smelting, Refining and Mining Co.l 
their present location as a result of faulting. Only the shales described by him as occurring on Prospect Ridge just north of Prospect Peak and in the mines on Ruby Hill belong to the Pioche shale.

The Pioche shale varies in lithologic character. The commonest variety of sediment is a sandy shale, commonly khaki or greenish in color, but locally reddish or even orange. The shale is characteristically micaceous, and close to the numerous minor thrust faults the micaceous shales are rather coarsely foliated. Locally some of the shales are calcareous rather than sandy; these range in color from grayish to khaki and are likely to be fossiliferous. Thin beds of reddishbrown micaceous sandstone and a few thin ones of quartzite lithologically like the Prospect Mountain quartzite are not uncommon.

In addition to the calcareous shales, several types of limestone are found within the formation. The commonest occurs as thin beds of mottled dark-blue limestone; most of these contain abundant trilobite fragments. A thin bed of black limestone was recognized just south of Prospect Peak; this variety appears to be uncommon. A conspicuous bed of limestone crops out in places from Prospect Peak north; it is as much as 20 feet thick and weathers white. Because of the minor faulting within the formation it is possible that there may be more than one of these thick beds. Exposures of such limestones on Prospect Ridge and on the west slope of the Ridge between Cave Canyon and the Prospect Mountain Tunnel are lenticular, but it is probable that the lenticularity is more the result of shearing than of variations in original deposition. In lithologic character these thicker beds resemble more the limestone in the Eldorado dolomite than the thinner beds of mottled blue limestone that are associated with it in the Pioche shale, but this may be the result of later alteration.

Like the Prospect Mountain quartzite, the Pioche shale forms smooth treeless slopes. The outcrop generally forms a depression between the two adjoining formations and is greener, owing to a slightly more abundant growth of grass. The thick white-weathering limestone beds weather in relief and make conspicuous bands within the unit.

The thickness of the Pioche shale at Eureka varies considerably. Its upper and lower boundaries are well marked by the thick sequence of quartzites below and massive limestone and dolomite above, so that the variations are almost certainly due to shearing, rather than to uncertainty about the exact location of the boundary. R. T. Walker ${ }^{2}$ estimated that about

${ }^{2}$ Walker, R. T., 1923, The Richmond-Eureka Mine: Private report prepared for the U. S. Smelting, Refining and Mining Company.
60 feet of beds was present in the Richmond-Eureka mine and Wheeler and Lemmon (1939, p. 31) measured 200 feet on Prospect Ridge. Our mapjing suggests that the unit may be even thicker locilly, perhaps as much as 400 to 500 feet, but the crumf ling that can be observed in the shaly beds and the lensing of the massive limestones indicates that detailed measurements would be subject to considerable error.

\section{AGE AND CORRELATION}

Hague (1892, p. 42, and atlas, sheet VII) shows two localities at which fossil collections wer made from beds now included within the Pioche shale. The more northerly of these, incidentally, appers to have included fossils from both the Pioche and the Secret Canyon shales, a fault wedge of which is nearby. Both yielded a fauna containing Olenellus and the enclosing beds were regarded by Hague (1892, p. 45) as "the equivalent of the lowest Cambrian fossiliferous strata in the Great Basin." Additional collections have been made by Geological Survey parties in recent years, both from Prospect Ridge and from the west slope of the ridge as far north as the small outcrop area north of the road leading to the Prospact Mountain Tunnel.

A. R. Palmer, of the U. S. Geological Survey, has studied six collections made from the Pioche shale by various Survey parties. Some of thes: were from sandy shales, others from the thin limestone beds. A. R. Palmer (1953, written communicetion) reports that

the arenaceous shale collections are stratigraphically below those made from the limestones and contain only remresentatives of the Olenellidae. The limestone collections contain trilobites belonging to groups that were dominant during much of Middle Cambrian time, in addition to olenellids ... Faunas similar to those in the limestones are found in the Ccrdilleran region from Mexico to Canada and characterize the latest Lower Cambrian Antagmus-Onchocephalus zone of Lochman. Faunal list

1. Arenaceous shales

Olenellus fremonti Walcott.

Paedumias nevadensis (Walcott).

Peachella iddingsi (Walcott).

2. Limestones

Antagmus sp.

Bonnia cf. B. laevigata (Rasetti).

Crassifimbria sp.

Olenellus sp.

Onchocephalus parvus Walcott.

Paedumias sp.

Periomma sp.

At the type locality of the formation at Pioche, Nev. (Walcott, 1908a; Westgate and Knopf, 1932), the Pioche as originally defined contains both Lower and Middle Cambrian faunas (Burling, 1914; Mason, 
1936; Deiss, 1938). Some recent authors have therefore proposed to restrict the name Pioche to the Lower Cambrian portion of the formation and have used the new name "Comet shale" for the upper portion. As the only fossils thus far collected from the unit at Eureka are Lower Cambrian, this revision of the type Pioche is not of importance so far as the local nomenclature is concerned. Like the Prospect Mountain quartzite, the Pioche shale interval is widely recognized through the eastern Great Basin, though the paleontologic evidence suggests that either or both Lower and Middle Cambrian strata may be present in the lithologic unit. Local names, such as Cabin and Ophir have been used in western and central Utah, but the interval retains its distinctive lithologic character. In general, the more westerly sections appear to be the older ones and the Eureka section, which is the most westerly of all for this latitude, may well be all of Early Cambrian age.

\section{EIDORADO DOLOMITE}

The Eldorado dolomite is the host rock of the Ruby Hill ore bodies. It is therefore an economically important formation and as such has received a considerable amount of study. Both the name and the limits of the formation have been changed since it was originally distinguished; and its supposedly favorable character as wall rock for the larger ore bodies, together with an imperfect knowledge of local structural relations, have led to the mapping of considerable thicknesses of the stratigraphically higher Hamburg dolomite as a part of the Eldorado.

The unit was originally described by Hague (1883, p. 254-255) and Walcott (1884, p. 184-285) as the Prospect Mountain limestone, from its occurrence on Prospect Ridge. In this original definition the formation did not include the beds now assigned to the Pioche shale, but did include those now separated as the Geddes limestone. As was the case with the Prospect Mountain quartzite, the discrepancy between the geographic name of the type locality and that assigned to the formation seems not to have been considered of any significance. Hague's final report on the Eureka district retained the name Prospect Mountain limestone, but included the Pioche shale beds at the base (Hague, 1892, p. 36-38, 41-44).

In 1908 Walcott renamed the formation the Eldorado limestone in order to avoid the use of "Prospect Mountain" for two different formations. He selected as the type locality the Eldorado Tunnel, which is near the north end of Prospect Ridge and about 2,000 feet slightly north of east from the portal of the Prospect Mountain Tunnel. The beds exposed in the vicinity of the Tunnel are near the top of the formation as it is now defined, and are highly brecciated and altered. The bedding planes that can be recognized are nearly vertical, and some are overturned to the west. The old mine workings are largely caved, and in 1939 only 97 feet of the lower, or main, Eldorado Tunnel was acressible. The site is far from an ideal type locality, but is perhaps a more satistactory one than the general reference to Prospect Ridge, since much of the rock mapped on the Ridge by Hague as Prospect Mountain Limestone is currently assigned to the Secret Canyon stale and younger formations.

The formation was again amended by Wheler and Lemmon in 1939, who split off the uppermost beds as a separate unit-the Geddes limestone-and used the more appropriate designation of dolomite(Whesler and Lemmon, 1939, p. 18-20). This definition is the one accepted in this report.

The Eldorado dolomite, like the two older formations exposed in the district, is restricted in its outcrop area. It is confined to Prospect Ridge and the southerly extension of the Ridge in Secret Canyon, but the formation by no means forms the continuous band of outcrop that is shown on Hague's map of the district. North of the Secret Canyon divide, the expos'res are discontinuous as a result of two minor thrust zones, the Eldorado occurring in each of the three thrust $k^{7}$ ocks.

The lowest of the three blocks is the one that includes the type locality. It is a triangular-shaped wedge whose apex is near the divide on Prospect Ridge, and extends down the west slope to include the working: of the Prospect Mountain Tunnel. The Eldorado in the middle plate lies concordantly above and to the east of the main mass of Prospect Mountain quart xite and can be seen in a number of places to override belts of Secret Canyon shale that were probably included in Hague's "Mountain shale." The third and highest plate includes the Eldorado dolomite of Ruby Hill and the outcrops of the formation along the east side of Spring Valley. This block of the dolomite commonly overlies Prospect Mountain quartzite with $\varepsilon$, thrust contact, but in a few places appears to dip westrard and rest in relative conformity on Pioche shale.

We have not found significant shale banc's interbedded with the Eldorado, although Hague (1892, p. 38) reports that several such layers exist. All the supposed occurrences of "Mountain shale" and other unnamed shale units that were examined proved to be parts of the Pioche, Secret Canyon, or Durderberg formations, or the Pogonip group. Also wcrthy of mention is the fact that the Eldorado dolomite mapped by Hague on Mineral Hill and on the east slope of Prospect Ridge in the vicinity of the Diamond mine 
has proved to be Hamburg dolomite, with associated younger and older thinner-bedded strata.

The Eldorado dolomite is almost wholly a massively bedded carbonate formation. Both Hague (1892, p. 37) and Wheeler and Lemmon (1939, p. 19) quote analyses that show a range in composition from nearly pure limestone to nearly pure dolomite. This range partly reflects variations in the original sediments, but in larger part it is believed to be the result of subsequent hydrothermal alteration, which accomplished dolomitization and dedolomitization. The original character of the unit has been further extensively changed by the intense deformation that the formation has undergone. To some extent shearing has caused recrystallization to coarsely crystalline marble; more widespread, however, is shattering and brecciation, which in many places has been accompanied by cementation of the fractured rock by numerous white calcite or dolomite veinlets. The extent of these several types of alteration has made it impracticable to subdivide the Eldorado into smaller units, even though several types of unaltered limestone and dolomite may be recognized.

The common lithologic variety of unaltered limestone is massively bedded and blue gray in color. Weathered surfaces of the limestone tend to be smoother than those of dolomite, and the rock as a result appears to have a brighter luster than the duller appearing weathered dolomites. The greater solubility of the limestone also commonly causes surfaces to be rilled or etched, rather than irregularly roughened as is characteristic of the dolomites.

The dolomites believed to be of sedimentary origin are commonly somewhat thinner bedded than the limestones -1 to 3 feet in thickness, as against 5 feet or more-and appear to exhibit a greater range of textural variation. The commonest variety is a rather uniformly dark blue to black dolomite of medium crystallinity; streaked and mottled beds also are found widely. Much less abundant is the white-speckled dark dolomite widely referred to as "Bluebird" in reference to the formation composed of strata with this texture at Tintic, Utah, described by Lindgren and Loughlin (1919, p. 28).

Many of the texturally distinctive dolomites are calcareous. This feature, together with the welldefined textures, and the absence of evidence of either recrystallization or brecciation suggest strongly that these dolomites are not hydrothermal alteration products, but sedimentary deposits, in which there has been only partial conversion of the calcareous sediments to dolomite in the course of diagenesis.

Dolomite composed of alternating beds or bands, a foot or so thick, of light and dark dolomite, may also be, at least in part, an original sedimentary variety. In many mine workings, however, there seems to be evidence that the lighter portions of the rock result from the alteration of an original dark dolomite.

One of the commonest lithologic types found in the Eldorado dolomite is a light-gray rather coarsely crystalline dolomite. Generally it is textureless, but in places it is vuggy and porous, and in some outcrops it appears to show traces or "ghosts" of old textures. From its spatial relationships to beds of known sedimentary origin, it is clearly a hydrothermal alteration product of both limestone and dolomite.

Where the limestones of the Eldorado dolomite have been deformed, the most common result is a streaked limestone marble, normally bleached to white from the original blue-gray color, and appreciabl' coarser in grain size. This variety of rock may be seen east of the stopes on the south flank of Ruby Hill; here both shearing and the adjacent intrusive have influenced the recrystallization. The marble has resisted dolomitization, and in places remnants of dolomite in calcite marble appear to provide evidence that there has been actual dedolomitization in areas of intense marmorization.

Dolomitic rocks, where deformed, have commonly fractured; underground, in many places, highly fractured dark dolomite may be seen in contact with, or even surrounded by, unfractured calcite marble. The degree and extent to which the dolomites of the Eldorado are locally brecciated is impressive. In the mine workings on Ruby Hill brecciation is losally so intimate and pervasive that it is impossible to obtain a standard-sized hand specimen. The crushed dolomite stands well in the walls of the drifts and crosscuts but can be broken easily with a pick.

The Eldorado dolomite is resistant to erosion and normally forms rather prominent outcrops. In the aggregate the formation is pale gray and is sparsely covered by shrubs or by pinyon and juniper, thus contrasting with the rather barren or grassy slopes underlain by the Prospect Mountain quartzite or Pioche shale.

Because of extensive alteration and shearing, it is difficult to determine accurately the thickness of the formation. Hague (1892, p. 38) reports a maximum figure of 3,050 feet but notes that "on Ruky Hill, owing to faulting, it never attains its full development." Wheeler and Lemmon (1939, p. 19) and Sharp (1947, p. 1) both use a thickness of 2,000 feet, and Wheeler and Lemmon believe that Hague's larger figure can be explained as due to repetition by faulting. Certainly the exposures of the Eldorado dolomite in the two upper thrust plates are so brecciated and faulted as to suggest that measurements made on them might be subject to considerable error. 
The plate underlying Ruby Hill, for example, not only has been explored by the mine workings, which indicate a minimum thickness in the order of 1,000 feet, but has also been cut by several diamond-drill holes. Two of these, holes $B$ and $C$ in the neighborhood of the Locan shaft of the Richmond-Eureka mine, penetrate Prospect Mountain quartzite beneath the thrust that limits the Eldorado dolomite downward. Between the thrust and an attenuated section of the Geddes limestone there were 807 and 864 feet of Eldorado, respectively. These figures contrast with the thickness shown by drill hole $A$, some distance to the northwest. Here 1,895 feet of Eldorado was cut before the hole terminated in a porphyry that may have been intruded along the lower thrust zone. Joralemon, ${ }^{3}$ however, in a private report to the Eureka Corp., Ltd., has suggested that the thrust is appreciably higher and that the Eldorado is in the order of 1,000 feet thick, the balance of the thickness of dolomite being assigned to Hamburg dolomite, lying below the thrust.

Wheeler and Lemmon measured their thickness of 2,000 feet in the middle thrust plate along Prospect Ridge. The more recent detailed mapping shows that here too the thrusts that bound the plate, as well as faults that cut the plate, make accurate measurements unlikely. The figure of 2,000 feet would appear to be not unreasonable, however.

The lower or third plate in which the Eldorado dolomite occurs, seems to offer the best opportunity to estimate the thickness of the formation. The steep west slope of Prospect Ridge just north of the Prospect Mountain Tunnel exhibits what appears to be a complete section with nearly vertical dips from the Pioche shale at the base of the Ridge to the Geddes limestone at the summit. About 2,500 feet of beds is present here, if the sequence is not interrupted by faults. None of major magnitude was recognized, but in the light of experience elsewhere in the Eureka district, it is hazardous to assume that they are absent.

The true thickness of the formation is therefore uncertain. Perhaps the best estimate is the 2,500-foot figure derived from the section north of the Prospect Mountain Tunnel, but it is not improbable that the formation may vary in thickness from plate to plate.

\section{AGE AND CORRELATION}

Hague (1892, p. 41-44) reported three fossiliferous horizons in the Eldorado dolomite: the lowest of Early Cambrian age, the upper one of Middle Cambrian age and a middle one intermediate in age. As pointed out above, Hague's lowest horizon is now assigned to the Pioche shale, and the intermediate one is mapped as a part of the Secret Canyon shale; it was included by
Hague within the Eldorado dolomite through his failure to recognize local faulting. The upper horizon, from which Hague and Walcott made several collections, including one from the Richmond-Eureka mine, is also no longer regarded as falling within the Eldorado, now being mapped as within the Geddes limestone.

The Eldorado dolomite thus cannot be dated by enclosed fossils, but its time range is limited by the upper Lower Cambrian Pioche shale below and the medial Middle Cambrian Geddes limestone above. Wheeler and Lemmon (1939, p. 20) assign it to Lower and Middle(?) Cambrian, but in view of the occurrence of a Middle Cambrian fauna in the Pioche shale at Pioche, we feel that an assignment to the early Middle Cambrian is probably more suitable.

The Eldorado dolomite, according to A. R. Palmer (1953, written communication), is the approximste age equivalent of the upper part of the Pioche shale, the Lyndon limestone, the Chisholm shale, and the lower half of the Highland Peak limestone of the Pioche district; the Tatow limestone of Deiss (1938), Burrows dolomite of Wheeler (1940), Burnt Canyon of Wheeler (1948), Dome and Swasey formations of Walcott (1908) in the House Range, Utah; and the Abercrombie formation of the Gold Hill district, Utah.

\section{GEDDES LIMESTONE}

The Geddes formation was defined by Wheeler and Lemmon (1939, p. 20-22) as including the well-k added strata between the massive limestone and dolonite of the Eldorado dolomite and the shale at the base of the Secret Canyon shale. The unit is distinctive and easily recognized and has been most useful in determining the structure of Prospect Ridge and Mineral Hill. The beds now assigned to the Geddes were recognized by Curtis $(1884$, p. 31) and were referred to by him as the "Stratified" limestone. Their stratigraphic position was not clearly stated by him, although by implication his references to the uppermost fossil horizon in the Eldorado would indicate that he may have been aware of the restriction of the "Stratified" limestone to the top of the Eldorado. The formation has alsc been recognized as a stratigraphic unit lying above the main body of the Eldorado by many mining geologists active in the district and was commonly referred to by them as the "Blue Flaggy" limestone. The maps of Ruby Hill prepared by geologists of the U. S. Smeltirg and Refining Co., for example, distinguish the "Blue Flaggy" as a separate unit. Some geologists, however, though regarding the unit as separable, considere it to be the basal member of the Secret Canyon shale. ${ }^{4}$

\footnotetext{
3 Joralemon, I. B., Aug. 20, 1949, Private report on Eureka Corp., Ltd.

4 Walker, R. T., 1923, The Richmond-Eureka Mine: Private preport raoared for the U. S. Smelting, Refining and Mining Co.
} 
The formation is exposed as a band of variable width east of the outcrop of Eldorado dolomite, from the south end of Secret Canyon, north along the east side of Prospect Ridge as far as the Diamond Tunnel of the Diamond mine. It also occurs in two bands on either side of Mineral Hill from the Eureka Tunnel at the head of Goodwin Canyon nearly to Ruby Hill. A few discontinuous outcróps are found on the west side of Prospect Ridge south of Prospect Mountain Tunnel in a zone of thrust slices, and also on the north and northeast sides of Ruby Hill, where they provide evidence on the throw of the Ruby Hill fault.

Lithologically the formation is unlikely to be confused with any of the other lower Paleozoic units at Eureka. It is made up in large part of well-bedded ("flaggy") dark-blue to black carbonaceous limestones, which are separated by thin dark shaly partings. The individual beds commonly range from 3 to 8 inches in thickness. A few beds are light gray in color and these not infrequently sbow finer banding. Small amounts of chert, normally nodular and black, are found in some beds, and constitute, with the exception of a tiny amount of white chert, near the base of the Hamburg dolomite, the only occurrences of chert at Eureka below the Upper Cambrian Windfall formation. Weathered surfaces of the Geddes limestone and blocky fragments of it have a characteristic reddish or purplish color. Calcite veining of the dark limestone beds is prevalent and is especially striking in underground exposures.

The contact of the Geddes limestone with the underlying Eldorado dolomite appears to be gradational, although in places this may result from folding or faulting rather than interlayering. On the northwest nose of Prospect Ridge, however, the evidence seems fairly clear that the two formations interfinger; here a bed of massive limestone 10 feet or more thick and resembling beds in the Eldorado can be mapped within the Geddes near its base. The upper contact with the Secret Canyon shale is not well exposed on the surface, but appears to be sharp. This is also true of the underground exposures, but the core of diamonddrill hole $E$ of the Eureka Corp., Ltd., north of Ruby Hill, shows 83 feet of shale within typical Geddes limestone. This, however, may be the result of local faulting.

Throughout much of the outcrop area on Prospect Ridge the limestones of the Geddes are closely folded, and the apparent thickness of the formation in this area varies gr eatly as a result of the widespread minor faulting that seems to be associated with the folding. In both the Prospect Mountain and Eureka Tunnels, for example, less than 50 feet of folded beds is cut.
The sections of the formation cut by the Eureka Corp. drill holes just north of Ruby Hill are likewise much faulted and in drill holes $B$ through $F$ the thickness of the Geddes appears to range from zero to slightly less than 200 feet. At the type locality-the Geddes and Bertrand mine in Secret Canyon-Whee'er and Lemmon (1939, p. 20) measured 335 feet in the tunnel between the mine and mill. In the Eurela Corp. drill hole $A$, some distance north of Ruby Hill, 331 feet were cut. A figure of about 330 feet, therefore seems to represent a true thickness for the formation. Exposures on the west side of Mineral Hill, southeast of the Charter Tunnel, however, seem to be 50 to 100 feet thinner on the average.

\section{AGE AND CORRELATTON}

Hague and Walcott collected from several localities the rocks of which are now assigned to the Geddes limestone, and Hague (1892, p. 43) reports the fossils as indicating a "mingling of both Georgia [Middle] and Potsdam [Upper Cambrian] faunas." A. R. Palmer, of the Geological Survey, however, has studied the eight collections made by Survey parties over a period of years and reports (1953, written communication) that

All of the trilobites are characteristic of the medial Middle Cambrian Bathyuriscus-Elrathina zone of Rasetti. The commonest forms are small agnostids and species of Elrathina.

The agnostid fauna has all of its genera and at laast one species in common with the Middle Cambrian agnostid faunas of Sweden. On the basis of these forms, the Bathyuriscus.Elrathina zone seems to correlate with at least part of the Paradoxides paradoxissimus stage of the Scandinavian Middle Cambrian.

The Geddes limestone is the approximate ag? equivalent of the Wheeler shale in the House Range, Utah; $r$ robably also of the upper part of the Abercrombie formation or the Young Peak dolomite of the Gold Hill district, Utah; and of units $H$ or $I$ of the Highland Peak limestone at Pioche.

Asaphiscus sp.

Faunal list

Bathyuriscus sp.

Diplagnostus sp.

Dorypyge sp.

Elrathia? occidentalis (Walcott).

Elrathina spp.

Goniagnostus? sp.

Hypagnostus parvifrons (Linnarsson).

Kootenia eurekensis Resser.

Olenoides expansus (Walcott).

Olenoides pugio (Walcott).

Orria sp.

Peronopsis sp.

Ptychagnostus (Ptychagnostus) richmondensis (Walcott).

Ptychagnostus (Triplagnostus) sp.

Zacanthoides spinosus (Walcott).

\section{SECRET CANYON SHALE}

The Secret Canyon shale was described by Hague (1883, p. 255) from its exposures in Serret Canyon, 
which heads on the south slopes of Prospect Peak and extends nearly due south from there. Hague elaborated on the original description in 1892 (p. 39); and Wheeler and Lemmon (1939, p. 23-25) have further described it. In all these descriptions the formation is defined as including the strata between what is now mapped as Geddes limestone and Hamburg dolomite. Walker ${ }^{5}$ enlarged the formation by including the Geddes limestone as a lower member, but this usage has not been generally accepted.

We have used the name in the original sense, but have distinguished and mapped two members: a lower shale unit, and an upper platy limestone member, for which the name Clarks Spring member is proposed from the especially good outcrops of the unit in the vicinity of Clarks Spring near the head of the southwesterly branch of New York Canyon. Hague (1892, p. 39) recognized that the upper portion of the formation included more limestone, and Wheeler and Lemmon (1939, p. 23) also reported that there were two "lithologically distinct mappable units" as did Walker ${ }^{6}$ in his unpublished earlier work.

The Secret Canyon shale is rather extensively exposed within the narrow belt of Cambrian strata that extends from Adams Hill on the north to the south end of Secret Canyon. Its outcrops form parts of three minor thrust plates and appear to show slight variations in the lithologic character or the thickness of the formation from one plate to another. In all three, however, the tendency of the unit to form a topographic depression between the more resistant limestones and dolomites stratigraphically above and below it is marked and has been commented upon by all previous observers. This is especially true of the exposures of the middle thrust plate, which extends from New York Canyon on the east side of Prospect Ridge southwards through Secret Canyon. At the north end of this series of outcrops, in New York and Windfall Canyons, the normal width of outcrop is materially increased by folding and faulting, and as a result there are broad basins cut in the formation at the heads of these two canyons. In addition to this characteristic topographic expression, the formation, especially the Clarks Spring member, is normally marked by a much heavier growth of vegetation than the adjoining limestones and dolomites.

Hague (1892, p. 39) estimated the thickness of the formation as ranging to as much as 1,600 feet, and Wheeler and Lemmon (1939, p. 23) report 1,035 feet at the head of Secret Canyon. It is probable that both these figures include some duplicaition of. strata as a result of either folding or minor thrust faulting

\footnotetext{
- Walker, R. T., 1923, The Rfchmond-Eureka Mine: Private report prepared for the U. B. Smelting, Refining,and Mining Co.
}

and that the true thickness of the Secret Canyon shale is closer to 650 feet.

\section{LOWHR SHALE MEMBFR}

The lower shale member is composed of a fairly uniform sequence of argillaceous shale, commonly with little or no interbedded limestone. It rarely crops out and its exact boundaries are in most places so mewhat conjectural, being based of necessity on the presence of small flakes of brown, red, or yellow shale fragments in the soil. The best surface exposures of the formation are in Cave Canyon on the west slope of Prospect Ridge where what is probably close to the full thickness of the member in the lower thrust plate is exposed in the bottom and along the walls of the canyon. These exposures are just below the zone of minor thrusts that bring in the beds of the middle thrust plate; they probably have been made more resistant to erosion by this deformation.

The lower shale member is also well exposed ir several of the underground workings, notably in the Prospect Mountain and Eureka Tunnels, and in a small tunnel near the head of Zulu Canyon, at an elevation of about 7,800 feet. Here, away from the effects of surface weathering, the unit is a massive, blocky siltstone, which has little or no fissility, and which is deep green to dark gray in color. Shaly structure in the Secret Canyon shale, as well as in the other shele units observed in the vicinity of Eureka, appears to be best developed where weathering has occurred.

With the exception of the section in drill hole $E$, in which an 83-foot band of the lower shale member occurred within the Geddes limestone (probak'y as a result of faulting), the contact between the lower member of the Secret Canyon shale and the Geddes appears to be sharp. There is a gradational contact between it and the Clarks Spring member, to judge from the exposures in Cave Canyon, where an appreciable thickness of shale may be seen overlying the basal 30 to 40 feet of platy limestone. The zone of interfngering between the two members appears to be even thicker and more pronounced in the exposures in the uppermost thrust plate in the gulch south of Adams Hill. Here there appears to be a zone about 100 feet thick in which thin limestone beds, half an inch thick or less, alternate with equal thicknesses of shale. In the mapping, this zone was included with the lower shaje member, although the grayish-green color of both the shale and the platy limestone is not typical of either of the two members in the other thrust plates.

On the west side of Mineral Hill, within a radius of about 2,500 feet from the quartz monzonite stock, the

\footnotetext{
- Walker, R. T., 1923, The Richmond-Eureka Mine: Private report prepared for the U.S. Smelting, Refining and Mining Co.
} 
shale has been metamorphosed by the intrusive to a hard dark-green hornstone without any indication of bedding.

The apparent thickness of the member appears to vary from 125 feet to somewhat over 500 feet, although these extremes seem to be the result more of duplication or thinning due to deformation than to original variations in thickness between the three thrust plates. In the lowest thrust plate, the lower shale member is approximately 200 feet thick, to judge from such measurements as can be made both on the surface and underground. Wheeler and Lemmon (1939, p. 23) report 505 feet for the thickness of the member near the divide between Windfall and Secret Canyons. The locality is within the zone of outcrop of the middle thrust plate, and it is probable that this figure is too large, owing to folding or repetition by minor thrusting. In the upper thrust plate, 5 of the Eureka Corp. drill holes yielded thicknesses of the member ranging from about 125 feet to 185 feet. These drill holes are all near the area on Ruby Hill where all the stratigraphic units are apparently thinner than normal; these thicknesses also appear to be less than the thicknesses exposed in the somewhat disturbed section shown in the gulch south of Adams Hill. Probably 200 to 225 feet is a fair approximation to the true thickness of the unit.

\section{CLARKS SPRING MEMBER}

The upper member of the Secret Canyon shale is made up of thin-bedded limestone with prominent yellow or red argillaceous partings, a type of rock that appears to be especially common in, and to some extent distinctive of, the Middle Cambrian sections in the Great Basin. An especially good exposure of the member is provided by the road cuts in upper New York Canyon, just north of Clarks Spring. From these the member takes its name, and they may be regarded as the type locality. Good exposures of the member are also provided in the gulch south of Adams Hill, west and south of Mineral Hill, and on the ridge line of Prospect Ridge above the Diamond Mine. The unit is also exposed in a number of the mine workings, and especially good sections may be seen in the Eureka and Prospect Mountain Tunnels.

The thin limestone bands are commonly a quarter to a half an inch thick and rarely exceed 2 inches in thickness. The limestone is fine grained, silty and blue gray in color, contrasting markedly with the yellow or, more rarely, red clay partings, which range from an eighth to a quarter of an inch thick. Although in most places the clay partings are even and regular, locally there are exposures, especially on surfaces parallel to the bedding, in which the argillaceous material is more irregularly distributed, yielding a rock that is strikingly mottled, rather than banded, with yellow or red patches.

As noted above, the contact between the Clarks Spring member and the lower shale member is gradational. This is also true of the upper boundary of the Clarks Spring, where there is normally a zone, as much as 50 feet thick, in which thick beds of limestone similar to those forming the base of the Hamburg dolomite alternate with the typical platy limestone of the Clarks Spring.

Southwest of the quartz monzonite plug on Ruby Hill the Clarks Spring member has been considerably metamorphosed. Nearer the intrusive both the limestone and the shale partings have been converted to silicate minerals, and the resulting hard dense rock can be distinguished from the similarly altered lower shale member only by the local preserval of color differences representing the original interlayering. Farther from the intrusive only the shale layers have been altered to silicate minerals, and on weathered surfaces these bands stand out in relief from the limestone lajers, which may be bleached to a lighter color. It is likely that the alteration of both members of the Secret Canyon shale is chiefly due to thermal, rather than additive, metamorphism.

As with the lower member of the Secret Canyon shale, the thickness of the Clark's Spring member varies considerably; but it is believed that the major variations are the result of deformation, rather than of original sedimentary differences. In the lowermost of the three thrust plates the member has a thickness of about 425 feet on the west side of Mineral Hill, but the exposures of the unit underground in the Prospect Mountain and Eureka Tunnels are much thinner because of faulting. For the middle plate Wheeler and Lemmon (1939, p. 30) obtained a thickness of 530 feet near the Windfall-Secret Canyon divide. It is likely, to judge from detailed mapping in the region, that the 530-foot figure may include some duplication of beds. In the upper plate, four drill holes of the Eureka Corporation, Ltd., near Ruby Hill yielded thicknesses ranging from about 150 to 160 feet. These figures, however, probably are considerably too small, as drill hole $A$, some distance to the north showed approximately 400 feet, with the uppermost beds missing as a result of truncation by the Bowman fault. This figure is in good agreement with an estimate of 450 feet made on the surface southeast of the summit of Adams Hill. A thickness of 425 to $4 E n$ feet for the Clarks Spring member is probably fairly close to the truth.

\section{AGE AND CORRELATION}

Although Hague (1892, p. 44) reported that no fossils had been found in the Secret Canyon shale, he 
regarded the age as being fairly well delimited by collections from the Geddes limestone below and the basal beds of the Hamburg dolomite above. Fossils were later found in the upper member of the formation, and these indicated a Middle Cambrian age. Considerable confusion arose as a result of this later collecting, since in one of the most accessible localities, just north of the Richmond shaft of the Richmond-Eureka mine on Ruby Hill, fossiliferous Secret Canyon shale has been brought into contact with abundantly fossiliferous Dunderberg shale by the Bowman fault. Mixing of the collections from the two formations finally resulted in the proposal (Resser, 1935, 1936, and 1937) that the Secret Canyon and Dunderberg shales were identical and of Late Cambrian age; the Middle Cambrian fossils from the Secret Canyon being assigned to the Eldorado.

Edwin Kirk (1932, oral communication) first called our attention to the likelihood of mixed collections, as a result of field work carried on by him with H. G. Ferguson in 1930. Wheeler and Lemmon (1939), p. 16-17), independently came to the same conclusion. A sketch of the geology at the critical locality is shown in figure 2; our fossil localities, which are probably very c'sse to
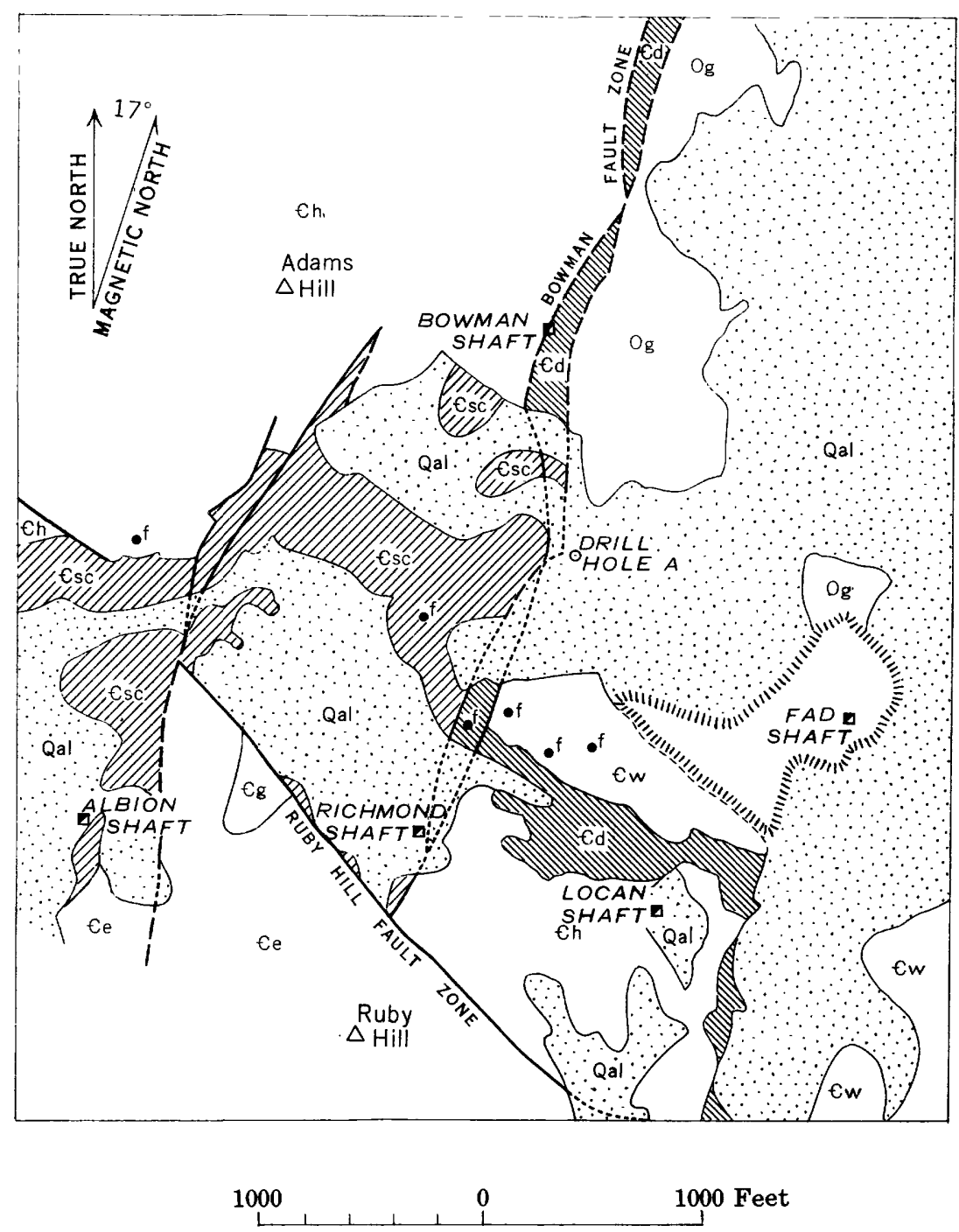

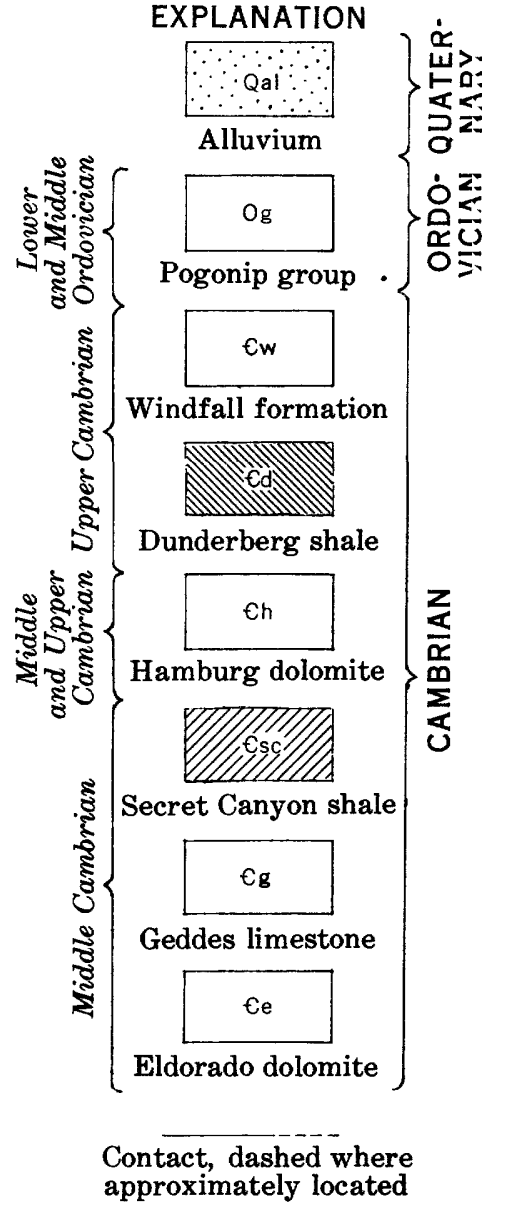

Fault, dashed where approximately located, dotted where concealed

Fossil locality

Drill hole

Mine shaft

Dump 
those of Hague, Walcott, and Resser, are also shown and make clear how easily the two shales could be confused.

The Middle Cambrian age of the Secret Canyon shale is clearly proved by the numerous collections made by Geological Survey parties in recent years (Palmer, 1954). These have come not only from the locality north of the Richmond-Eureka mine, but also from outcrops of the formation in Goodwin Canyon, on Prospect Ridge, and in Secret Canyon. All 12 recent collections have come from the Clark's Spring member and all but 1 came from the interval above the prominent limestone ledge near the top of this member. The single collection from below this ledge, according to A. R. Palmer (1953, written communication), carries the same trilobites as those from above. Palmer reports:

The fauna is characterized by abundant specimens of a species of Modocia nevadensis Palmer (Ptychoparia oweni of Walcott) and common specimens of Eldoradia and Bolaspidella. These trilobites seem to be characteristic of late Middle Cambrian deposits in the Great Basin.

On the basis of the distribution of Eldoradia, the Secret Canyon shale is the approximate age equivalent of the Marjum limestone in the House Range, Utah; units $J$ ? and $K$ of the Highland Peak limestone at Pioche; and the Trippe limestone of the Gold Hill district, Utah.

Agnostus sp.

Faunal list

Alokistocare? sp.

Asaphiscus sp.

Bolaspidella spp.

Eldoradia prospectensis (Walcott).

Eldoradia linnarssoni (Walcott).

Elrathiella spp.

Modocia nevadensis Palmer.

Olenoides? sp.

Solenopleurella sp. (Walcott).

\section{HAMBURG DOLOMITE}

The Hamburg dolomite was originally described by Hague $(1883$, p. $255 ; 1892$, p. 39-41) as the Hamburg limestone, a ridgemaking unit that overlaid the less resistant Secret Canyon shale and was itself overlain by the weak Dunderberg shale. The type locality is at the Hamburg Mine in a southern branch of New York Canyon. Here, the formation is not well exposed, because of considerable faulting and shearing along the contact with the overlying shale. The limits of the unit have not been materially changed by subsequent geologic work, but the use of dolomite rather than limestone was proposed by Wheeler and Lemmon (1939, p. 25). We have adopted this emendation.

The Hamburg dolomite, like the other Cambrian formations, is restricted to a narrow north-south belt of rocks that extends in either direction from Prospect Peak. One continuous band of exposures extends from near the head of Shadow Canyon, through the Eureka Tunnel and the Hamburg and Windfall mines in Goodwin, New York, and Windfall Canyons, respectively, and then southward the length of Secret Canyon, of which it forms the east wall. Four smaller isolated masses of Hamburg have been mapped west and north of this elongate band. The most northerly underlies Adams Hill, where perhaps the best expo ures of the formation may be seen, and which might better have been chosen as the type locality. The other three were all included in earlier mapping as a part of the Eldorado dolomite. One of them forms the northeast shoulder of Ruby Hill, where it is exposed on the surface and in the workings and drill holes from the Locan shaft of the Richmond-Eureka mine; the second is the mass underlying Mineral Hill; the third is on Prospect Ridge at the head of New York Canyon, where the mine workings in the Diamond and adjoining mines have explored the block extensively. The Mineral Hill b? ock extends northward below the surface and is found in the lower levels of the Richmond-Eureka mine on Ruby Hill. Here it was identified as "Back limestone" or "Lower Prospect Mountain limestone" in some unpublished mine reports. Hague reports another isols.ted outcrop of Hamburg a few miles south of Prospect Peak and west of Secret Canyon (1892, p. 129); we have not examined the locality, the fossils from which are reported to resemble those from the middle part of the Pogonip group as well as the Hamburg.

In the field the Hamburg dolomite gives the impression of being a fairly uniform, thick-bedded, dark-gray unit. To a considerable extent, however, the apparent uniformity probably is more the result of deformation and alteration, than of original similarity of sedimentation. Traverses across the Hamburg usually reveal, among the massively bedded rocks, beds of both limestone and dolomite, and textural varieties that include banded and mottled dolomites, as well as dolomite containing white rods in a darker matrix ("Bluebird" lithologic type). In a few places intraformational dolomite conglomerates and dolomites with oval algallike growth may be found. Interbedded light and dark dolomites, which are not infrequent, probably represent, in part, variations in original litholog: character.

There are some especially distinctive roc ${ }^{\mathrm{t}}$. types near the base of the formation. As described in the previous section on the Secret Canyon shale, there is a gradational contact between the two, and kads of platy limestone typical of the upper part of the Secret Canyon alternate with thicker beds of crinkly-bedded and mottled dark-blue limestone that are typical of the base of the Hamburg. Narrow stringers of chert are commonly found in this limestone. A short distance above the limestone the Hamburg, where unaltered, is 
characterized by well-banded saccharoidal dark dolomite. This is especially well exposed on the 200 -foot level of the Bowman mine shaft and also in the Fad shaft of the Richmond-Eureka mine.

Much of the Hamburg, however, is composed of a dull-gray rather coarsely crystalline dolomite, whose color ranges trom a light to medium gray; this rock is porous or vuggy, and probably is in considerable part the product of alteration. Normally, the altered rock is shattered or brecciated, in many places highly so, and contains appreciable amounts of iron-sivined silica, either as thin seams cementing the breccia fragments, or as irregular masses of jasperoid. Introduced silica of both these varieties is especially abundant in the dolomite immediately beneath the Dunderberg shale. Bedding planes are obscure or lacking in these rocks, which make up a large part of the rugged ridges underlain by the formation.

On Mineral Hill, adjacent to the quartz monzonite stock, the formation is even more intensely altered. Over much of the ridge south of the intrusive the dolomite has been recrystallized to a coarse-grained white dolomite marble, individual grains in places being half an inch across. Immediately adjacent to the intrusive the rock has been converted to a massive aggregate of silicates, which are locally accompanied by concentrations of magnetite or pyrrhotite. The silicate rock is composed chiefly of diopside and garnet, but includes other less common minerals, such as the manganese epidote, thulite (Schaller and Glass, 1942). Hague mentions these metamorphic rocks briefly (1892, p. 106-107), although he concludes that the quartz monzonite with which they are associated is probably of pre-Cambrian age (Hague, 1892, p. 116). Some mining geologists have in the past distinguished the metamorphic rocks (which in places may include altered strata of the Secret Canyon shale) as the "Hope Greenstone". Detailed mapping and mineralogical study show quite clearly, however, that the rocks have undergone contact metamorphism, rather than being a separate unit of volcanic origin.

Both on the surface and underground, most of the Hamburg dolomite is indistinguishable from the Eldorado dolomite. It is probable that this is due chiefly to the fact that both units have been subjected to the same types of deformation and alteration-at least as much due to this as to similarities in original sedimentation, although identical lithologic types can be recognized in relatively unaltered parts of both formations. One unfortunate conclusion that arose from the early work of Hague and his associates was that the richer ore bodies were restricted to the Eldorado dolomite. There has been therefore a considerable incentive to identify masses of dolomite as belonging to the older formation. The relatively reent determination that the host rock of the IiamondExcelsior ore bodies is Hamburg dolomite, however, indicates that both formations can be the site of rich ore bodies, a conclusion that might have beer reached much earlier if more emphasis had been placed on the physical and chemical properties of the carbonate rocks as a critical factor in ore deposition rather thar the age.

Hague (1892, p. 40) reported that the Jamburg dolomite was 1,200 feet thick, and Wheeler and Lemmon (1939, p. 25) measured 900 feet on the divide between Windfall and Secret Canyons. Evidences of considerable dislocation along both strike and cross faults disclosed by detailed mapping cast considerat ${ }^{l} \mathrm{e}$ doubt on most of the natural sections exposed on the surface. The Locan shaft of the Richmond-Eureka mine on the northeast shoulder of Ruby Hill and the 900-foot level from that shaft are very largely in the Famburg. Here sections constructed through the mine and the several drill holes put down from the 900-foot level indicate a thickness for the formation of about 1,050 feet, although it is possible that unrecognized faulting may have caused some duplication. Very recent drilling on Adams Hill by the Eureka Corp., Ltd., has penetrated apparently complete sections of the Hamburg that are only 500 to 600 teet thick. It is difficult to reconcile these lower figures with the seversl indications of a thickness close to 1,000 feet. Pending additional subsurface information, it seems preferable to assume that the lower figures from Adams Hill result from cutting out of beds as a result of faulting--perhaps related to the sill that is intruded in the section just to the north at the Bullwhacker Mine-and that the true thickness is close to 1,000 feet.

\section{AGE AND CORRELATION}

Hague and Walcott made several fossil collections from the Hamburg dolomite, which Walcott (in Hague, 1892, p. 319) regarded as indicative of tha Upper Cambrian. All but three of the Hague and Walcott collections (as shown by the location of their collections on the Atlas sheets of Monograph 20) came from the base of the formation; of the remaining three, one came from the locality west of Secret Canyon mentioned above, one from near the middle of the formation on the west slope of Roundtop Mountain near the south end of Secret Canyon, and the third from a locality east of north of the Richmond-Eureka mine dump, probably from beds that we have mapped as Dunderberg shale. Geological Survey parties have collected from three localities in the formation, all of them at the base; and two of these collections are from the same localities as the Hague and Walcott collections. 
A. R. Palmer (1953, written communication) has studied these collections and reports that the trilobite fauna from them

is essentially the same as that of the underlying Secret Caynon shale except for the absence of species of Eldoradia and the addition of Holteria problematica (Walcott) and Kormagnostus seclusus (Walcott). The common forms are still Modocia nevadensis Palmer and species of Bolaspidella. The age of the fauna is considered to be youngest Middle Cambrian. Since the age of the Dunderberg shale, which conformably overlies the Hamburg dolomite is of late Dresbach age, the Hamburg dolomite is both Middle and Late Cambrian in age. It is the approximate age equivalent of units $L$ to $Q$ of the Highland Peak limestone, and the lower part of the Mendha formation of the Pioche district; the Weeks formation of the House Range, Utah; and the Lamb dolomite and most of the Hicks formation of the Gold Hill district, Utah.

\section{Faunal list}

Agnostus sp.

Asaphiscus laeviceps (Walcott).

Bolaspidella spp.

Holteria problematica (Walcott).

Kormagnostus seclusus (Walcott).

Modocia nevadensis Palmer.

Olenoides? sp.

Rowia sp.

\section{DUNDERBERG SHALE}

The Dunderberg shale was originally defined by Hague $(1883$, p. $255-256 ; 1894$, p. 41) as the Hamburg shale from exposures in the vicinity of the "Hamburg and Dunderberg" mines. In order to avoid the use of Hamburg for two formations in the same district, Walcott much later $(1908 \mathrm{~b}, \mathrm{p} .184)$ proposed the name "Dunderberg" for the shale unit. The latter name has been generally accepted and is used in this report. It is not quite certain, however, whether or not the top of the unit as mapped by Hague is exactly equal to the one currrently used. Hague writes of the shale as having near the top persistent layers of chert and sand. It is probable that these layers have been included by us within the overlying Windfall formation, though we included, as apparently did Hague, all beds of flaky shale of any appreciable thickness within the Dunderberg.

The Dunderberg shale has a distribution that is similar to that of the Hamburg dolomite. The chief exposure is in a band lying immediately east of the outcrop of the Hamburg, and extending from Shadow Canyon to the south end of Secret Canyon; the Dunderberg shale band is, however, thinner and is locally interrupted by faulting. The Dunderberg is also extensively exposed along the north side of the Adams Hill block of Hamburg dolomite. It occurs here also in a series of fault slices within the Bowman fault zone along the east side of the block and continues south along the fault zone to the Ruby Hill block. Here it overlies the Hamburg dolomite conformal!y near the mine office and extends down the gulch to the west as far as the Bowman fault near the tip of the RichmondEureka dump. Slices of shale are also found along the Jackson fault zone east of the Ruby Hill block, and at least two belts of thin slivers of the shale crop out on the east side of Prospect Ridge at the read of New York Canyon. These belts are especially significant in that they indicate major duplications in the thickness of the Hamburg dolomite at this locality and by implication cast doubt on apparent great thicknesses of the carbonate rocks in both the Hamburg and Eldorado formations at other places.

The Dunderberg shale is composed of afnroximately equal thicknesses of shale and of zones of interbedded shale with thin nodular and lenticular limestone. The shale normally appears at the surface as tiny brownish or khaki-colored flakes, each less than half an inch across. Although quite similar to the shale in the lower shale member of the Secret Canyon; the Dunderberg shale flakes on the whole are a somewhat deeper brown color than those of the older shale. Like it, however, underground exposures of unsheared shale are blocky and darker colored.

The shale interbedded with the nodular limestone is similar lithologically. The limestones aro quite distinctive, however, and are unlike any other limestones in the Eureka district. They range from half an inch to perhaps 6 inches in thickness and are characterized by nodular or "bumpy" surfaces. They are dense to medium grained and are blue gray on fresh fracture. Weathered surfaces are browner and commonly show a fine wavy banding or lamination that is in part at least due to sections through trilobite carapaces. Some beds are so crowded with trilobite fre rments that bedding surfaces are almost completely covered by them. Some of the limestone beds are also flecked with small pellets and films of yellow brown clay.

The boundary of the shale with the Hamburg dolomite is sharp and without evidence of intergradation at all places where it could be observed. It is, however, a zone of shearing, so that the abruptness of the contact may be structural rather than stretigraphic in origin. Several exposures of the sheared and contorted shale at the contact give no suggestion of original interbedding of shale and dolomite. The upper contact with the Windfall formation is also sl arp, though it appears to be a normal one. It has been taken as the contact between a thick bed of shale and a 28 -foot bed of massive limestone; the horizon seems to be persistent throughout the area mapped. Both the Hamburg dolomite below the Dunderberg shale and the basal beds of the Windfall above it are not uncommonly silicated, and at the divide to Serret Canyon 
south of the Windfall Mine, the Dunderberg itself is locally replaced by silica.

Hague (1892, p. 41) attributed a maximum thickness of 350 feet to the Dunderberg shale, and Wheeler and Lemmon (1939, p. 29-30) measured 340 feet at the divide between Secret and Windfall Canyons. We measured 265 feet on the ridge in Windfall Canyon immediately east of the new Windfall shaft and some 1,000 feet north of the old Windfall mill. This locality was chosen as the one that appeared to provide both the best exposures and the least structural disturbance. The somewhat smaller figure may reflect in part the assignment by us of some beds at the top of the shale to the Windfall formation rather than the Dunderberg, but it is probably chiefly due to duplication of beds at the other localities by the very widespread crumpling and shearing that the Dunderberg has undergone.

\section{Section of Dunderberg shale, measured on the ridge in Windfall Canyon}

[Immediately east of New Windfall shaft, 1,000 feet north of Old Windfall mill]

Base of Windfall formation.

Brownish shale

Limestone, interbedded, medium to fine-grained, bluish-

gray; in thin beds interlayered with shale; coarser

grained limestone at base.........................

Brownish shale predominates; a few limestone interbeds -

Limestone interbedded, thin, and shale..............

Brownish shale

Top of Hamburg formation.

Total thickness Dunderberg shale

\section{AGE AND CORRETATION}

Hague reports at least six localities in the Dunderberg shale from which fossil collections were made; Walcott (in Hague, 1892, p. 319) assigns all these collections to the late Cambrian. It is probable that some of these localities are included by us in the Windfall formation, and it is fairly certain that a collection shown by Hague and Walcott as coming from either the upper part of the Secret Canyon shale or the basal part of the Hamburg north of the Richmond shaft of the Richmond-Eureka mine was actually made at least in part from the Dunderberg. Since Hague's map was plotted in the office after the completion of both the geologic and topographic work, it is difficult to determine precisely the location of his collections with respect to our mapping; any comparison of faunas listed by Walcott with those from modern collections should take into consideration the probability that the two may not be exactly comparable.

The fauna from the Dunderberg shale as currently mapped is a large one and has been studied by a number of paleontologists in recent years (Palmer, 1955). A. R. Palmer (1953, written communication) has reported on 16 Survey collections and writes as follows:
The age of the Dunderberg shale is late early Late Cambrian and early middle Late Cambrian or, more simply, of late Dresbach and early Franconia age in the standard Late Cambrian time scale.

The commonest trilobites are species of Dunderbergia and the agnostids Geragnostus tumidosus (Hall and Whitfield) and Pseudagnostus communis (Hall and Whitfield). Evinia the guide to the base of the Franconia, first appears torards the top of the Dunderberg shale.

This formation is the approximate age equivalent of a part of the Mendha formation in the Pioche district; the Orr formation in the House Range, Utah; and the upper part of the Hicks formation and lower Chokecherry dolomite(?) of the Gold Hill district, Utah.

A relatively thin unit of clastic rocks containing the Dunderberg fauna is one of the most widespread stratigraphis markers in the Cambrian of the Great Basin. Elements of the fauna have been collected over an area extending from the lower Nopah formation in southeastern California to an unnamed formation in the Hot Springs Range near Golconda, Nevada, and eastward to the top of the Opex dolomite in the Tintis district, Utah. Much of the Dunderberg trilobite fauna is urdescribed and therefore cannot be listed.

\section{Faunal list}

Berkeia affinis"(Walcott).

Burnetia sp.

Cheilocephalus sp.

Dokimocephalus pernasutus (Walcott).

"Dunderbergia" granulosa (Hall and Whitfield).

Dunderbergia nitida (Hall and Whitfield).

Dunderbergia halli Resser.

Dunderbergia simulator (Hall and Whitfield).

Elvinia roemeri (Shumard).

Geragnostus tumidosus (Hall and Whitfield).

Housia spp.

Iddingsia nevadensis Resser.

Iddingsia robusta (Walcott).

Iddingsia similis (Walcott).

Irvingella sp.

Litocephalus richmondensis (Walcott).

Parabolinella sp.

Parairvingella angustilimbata Kobayashi.

Parairvingella eurekensis Resser.

Pseudagnostus communis (Hall and Whitfield).

Pterocephalia occidens (Walcott).

Pterocephalia sanctisabae Roemer.

Pterocephalina bilobata (Hall and Whitfield).

\section{WINDFALL FORMATION}

The Windfall formation was not differentiated in the earlier work in the Eureka district. The beds here assigned to it were included as the basal portion of the Pogonip formation, which Hague in his reports on Eureka $(1883$, p. $260 ; 1892$, pp. $48-54)$ redefined to include the strata between the Dunderberg sl ale and the Eureka quartzite. Both Hague and Nalcott, however, recognized that the Pogonip even as thus restricted contained at the base faunas that were more closely related to the underlying Cambrian than to those higher in the formation. Walcott therefore in 
1923 (p. 466) proposed that these lower beds be removed from the Pogonip and placed in a new formation to be called the Goodwin formation, with Goodwin Canyon southwest of the town of Eureka as the type locality. The Goodwin, however, as defined by Walcott, included much more than the Cambrian portion of the Pogonip, as that is now understood. Nearly 1,000 feet of beds of Early Ordovician age also seem to have been assigned to the Goodwin, which was intended by Walcott to include all strata belonging to the proposed Ozarkian system and thus include beds of both latest Cambrian and earliest Ordovician age, in terms of our present usage.

The Cambrian portion of Hague's Eureka Pogonip formation does, however, constitute a mappable unit in the Eureka district. We are reluctant to use the name Goodwin for the unit, since the Goodwin as originally defined by Walcott includes an apparently greater thickness of Ordovician strata as well. We therefore propose the name Windfall formation for the rocks of Cambrian age at Eureka between the Dunderberg shale and the Pogonip group as restricted. The type locality for the formation is designated as Windfall Canyon, just north of the old Windfall mine.

The Windfall formation has been mapped only within the area covered by the Eureka mining district quadrangle, where it extends in a nearly continuous band from north of the Bullwhacker mine at the north tip of Adams Hill and thence just east of the Bowman, Jackson, Dunderberg, Croesus, Hamburg, and Windfall mines to the south edge of the special sheet. Thrust slices of the formation are also found on the east slope of Prospect Ridge above the Diamond mine.

The formation probably continues south of the Eureka mining district quadrangle on the east side of Secret Canyon in a band paralleling the Dunderberg shale. It is also probable, to judge from Hague's descriptions, that beds belonging to the Windfall formation may occur further southwest in an isolated outcrop, mapped by him as Pogonip, south of Surprise Peak on the west side of Ratto Canyon (Hague, 1892, p. 130), and in the vicinity of Wood Cone (Hague, 1892, p. 123).

Strata that resemble the Windfall formation both lithologically and faunally have also been recognized in the vicinity of Ninemile Canyon at the north end of the Antelope Range, about 25 miles airline southwest of Eureka. We have not done sufficient mapping at this locality, however, to determine if the beds constitute a comparable map unit such as we have found at Eureka. A greater proportion of clay and silt, both as a separate shale unit and in thinner bedded shaly limestone, than is found at Eureka suggest that the limits of the Windfall in the Antelope Range may not be sufficiently distinct lithologically to permit its being readily separated from the higher Pogonip group. It will probably be necessary to extend our mapping southward through the Fish Creek Range to the Antelope Range before the full extent of the Windfall formation as a mappable unit can be determined in this direction.

The Windfall formation in Windfall Canyon is close to 650 feet thick, and this figure appears to be approximately correct for the whole area of outcrop in the vicinity of Eureka. A section measured at Ninemile Canyon in the Antelope Range suggests a thickness of about 500 feet, but the boundaries of the formation there are not accurately defined.

We have divided the formation at Eurela into two members: a lower unit, here designated the Catlin member from the exposures near the Catlin shaft of the Croesus mine in New York Canyon, composed of interbedded massive limestone, in part cherty, and thin-bedded shaly and sandy limestone; ard an upper unit, named the Bullwhacker member from exposures in the vicinity of the Bullwhacker mine, which is composed of a rather uniform sequence of thin-bedded platy and sandy limestones.

\section{CATLIN MGMBER}

The Catlin member is characterized by ar alternation of more massive limestone beds with thinr er sandy or silty limestones and by the abundance in the lower half of the unit of chert, much of it with light-ar d dark-gray laminations. The limestone beds normally are more resistant to weathering than the thinner bedded strata between them, and in areas of good exposures five massive beds form prominent outcrops. In less favorable areas only two or three massive beds are apparent, but these serve to identify the presence of the member between the smooth slopes made by the Dunderberg shale below and the Bullwhacker member $\varepsilon$ bove.

The massive limestone beds are for the most part fine grained, although some are coarser grained; some of the coarser beds are, like the limestones of the Dunder. berg shale below, crowded with trilobite fragments. The thinner bedded limestones are light to medium gray or blue gray in color and have santy or shaly interbeds that weather to brown or pinkish brown. These exhibit crinkly or lumpy bedding planes in many places. The banded chert layers are limited to the 120 feet at the base of the member above the lowest chertfree massive limestone. The chert itself iv commonly laminated by the alternation of dark- and light-gray to white chert.

The low ridge on the south side of Wind fall Canyon just east of the New Windfall shaft, which is a part of the type locality of the Windfall formation, is underlain 
by a well-exposed sequence of the Catlin member. A section measured here includes 250 feet of beds, a figure that appears to be valid for the unit throughout the mapped area around Eureka.

Section of Catlin member, Windfall formation, on low ridge south of Windfall Canyon east of the New Windfall shaft

Limestone, massive; lower 10 feet thinner bedded........

Limestone, thin, platy, for the most part laminated; with pinkish to buff crinkly sandy and shaly interbeds. One thin chert bed. 10-foot more massive medium- to darkgray limestone zone 20 feet above base, weathers to slightly bluish.

Limestone bed, massive; no chert.

Limestones, thin-bedded, platy, sandy and shaly, crinkly interbeds weather tan to slightly pinkish; local chert. -

Limestone, massive, bluish-gray, with bands of dark laminated chert; bedding somewhat crinkly ...........

Limestone, thin-bedded, platy, laminated; interbedded banded light and dark chert...........................

Limestone, massive, fine-grained light-gray; without

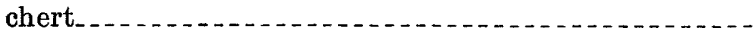

Total thickness, Catlin member.

The laminated chert zone of the Catlin member was recognized east of the mouth of Ninemile Canyon at the north end of the Antelope Range. Here the strata are in the main dark gray to bluish gray fine grained, partly silty to sandy limestones which are flaggy or thin bedded. At this locality the shales of the Dunderberg have not been recognized below these beds, and the laminated gray and black chert was found only in the upper part of the unit. Above it there is a 150foot gray shale member not recognized in the type Windfall. The shale contains Crustacea of the Caryocaris type similar to those found in the graptolite facies of the Vinini formation. The shale member in Antelope Valley is provisionally included with the Windfall formation as its uppermost division. Thickness of these strata, including the shale, is about 500 feet.

There has clearly been a considerable facies change between the Antelope and Eureka sections; if the chert zone is continuous with that at Eureka, it adds weight to the belief that here, as elsewhere in the Paleozoic rocks of Nevada, chert zones may be of wide geographic extent and of some importance as stratigraphic markers.

\section{BULLWHACKER MEMBER}

The Bullwhacker member takes its name from the exposures in the vicinity of the Bullwhacker mine. Here the member is fairly well exposed, though probably somewhat more disturbed by faulting than in Windfall Canyon, where one section was measured. The member is lithologically fairly uniform throughout, and the several hundred feet of thin-bedded tan or light-brown sandy or shaly limestone between units characterized by massive limestones make it easily recognized and mapped, except in the most corplexly faulted areas.

The Bullwhacker member is made up of platy or shaly limestone, some of which is slightly silty; on fresh fracture the color ranges from medium light to medium dark gray. The shaly or sandy partir ons and thin interbeds weather to buff or pinkish, and the whole member has a collective yellowish-tan color that is distinctive. The limestone beds are from a quarter of an inch to an inch thick and are fine grained to subporcellaneous in texture; they may show a slightly pinkish color beneath the gray. Lumpy and pitted surfaces are common, particularly where the limestone is somewhat silty. Gray chert nodules are found in places, but are generally rare. Horizons at which there are abundant trilobite and phosphatic brachiopod remains are fairly common.

The Bullwhacker member at Eureka appears to be conformable with both the Catlin member below and the Pogonip group above. Furthermore, the sandy or shaly thin-bedded limestones that characterize it are abundant in the Catlin member and are also fcund in the overlying Pogonip; in addition the massive limestone beds in the lower part of the Pogonip are quite similar to those in the Catlin, though they do contain locally some nodular white chert that appears to be absent from the Catlin strata. The distinctiveness of the member, which is easily mappable, is thus primarily due to uniformity in lithologic character, rather than to any distinctive lithologic type.

At Ninemile Canyon in the Antelope Rangs, beds lithologically similar to those making up the Upper Cambrian Bullwhacker overlie the 150-foot Caryocaris shale, which is above the strata correlated with the Catlin. However, the rocks at Ninemile Canyon that are similar to the Bullwhacker have not yielder Bullwhacker fossils; on the contrary, they bear the Early Ordovician Kainella fauna of the Goodwin limestone. In the Ninemile section these Lower Ordoviciar strata of Bullwhacker lithology continue upward for sone 600 feet from the top of the Caryocaris shale to an horizon characterized by chert-bearing limestones. At Eureka similar cherty limestones mark the base of the Goodwin. Thus, on paleontologic grounds it would appear that the Bullwhacker depositional environment rises in the time scale from Late Cambrian to Early Ordovician as it is traced southwestward. As a corollary, it may be that the problematic Caryocaris shale at Ninemile Canyon is actually a western facies of Bullwhacker age.

In Windfall Canyon the member is $\mathbf{4 0 0}$ feet thick, and this thickness appears to be essentially constant throughout the area that was mapped. 


\section{AGE AND CORRGLATION}

Numerous collections from both members of the Windfall formation have been made in the vicinity of Eureka by Geological Survey and U. S. National Museum parties in recent years. The collections have been studied by G. A. Cooper of the Museum; the late Josiah Bridge, of the Geological Survey; and A. R. Palmer, of the Geological Survey.

Mr. Palmer has recognized two distinct faunas in the collections from the Catlin member of the Windfall formation. He (Palmer, A. R., 1953, written communication) writes:

The lowest massive limestone contains a fauna characterized by Pseudagnostus prolongus (Hall and Whitfield) and species of Elvinia and Irvingella that differs only slightly from that of the underlying Dunderberg shale. The remainder of the unit has a fauna characterized by Bienvillia corax (Billings) and Lotagnostus obscurus Palmer that is unlike any that has been described from western United States. Many of the elements of the fauna have been described from boulders in the Levis conglomerates in Quebec. Trilobites collected recently from the Hales limestone in the Tybo district and from the "Pogonip" equivalents in Frenchmans Flat seem also to represent this undescribed fauna. Some of the trilobites of this upper fauna are characteristic of rocks of late Late Cambrian (Trempeleau) age. The age of the Catlin member therefore is middle and late Late Cambrian.

This unit is probably the age equivalent of the upper part of the Mendha formation at Pioche; part of the Notch Peak limestone in the House Range, Utah; and part of the Chokecherry dolomite (?) in the Gold Hill district, Utah.

No representatives of the Conaspis and Ptychaspis zones of the Franconia of the standard Upper Cambrian sequence are known from the Eureka district.

\section{Faunal list}

Lower fauna.

Burnetia sp.

Dunderbergia maculosa (Hall and Whitfield).

Elvinia roemeri (Shumard).

Geragnostus tumidosus (Hall and Whitfield)

Glyptagnostus reticulatus (Angelin).

Iddingsia similis (Walcott).

Irvingella major (Ulrich and Resser).

Kinbladia sp.

Litocephalus richmondensis (Walcott).

Parabolinella spp.

Parairvingella sp.

Pseudagnostus prolongus (Hall and Whitfield).

Pterocephalia sanctisabae Roemer.

$X$ enocheilus sp.

?Ptychopleurites eurekensis Kobayashi.

Upper fauna:

Acheilus? sp.

Apatokephaloides? sp.

Bienvillia corax (Billings).

Eurekia sp.

Geragnostus sp.

Hungaia? sp.

Idiomesus sp.

Leiocoryphe? sp.

Lotagnostus obscurus Palmer.
Platycolpus sp.

Plethomelopus sp.

Pseudagnostus convergens Palmer.

Richardsonella sp.

Saukiella sp.

Tatonaspis sp.

Tostonia iole (Walcott).

G. A. Cooper identified a Lingulella n. sp. and Finkelnburgia n. sp. in collections from the Catlin.

Palmer reports that the fauna of the Bullwhacker member is

dominated by specimens of Elkia nasuta (Walcott) (=Parabriscoia spp. of Kobayashi) and Eurekia granilosa Walcott, which are characteristic of rocks of late Late Cambrian (Trempeleau) age. $E$. granulosa Walcott is also found in the basal part of the Pogonip group.

The Bullwhacker member probably correlates with slightly younger horizons in the same lithologic units as the Catlin member.

Apatokephalus? sp.

Faunal list

Bowmania americana (Walcott).

Briscoia nevadensis Resser.

Calvinella tenuisculpta Walcott.

Corbinia sp.

Elkia nasuta (Walcott).

Euptychaspis kirki Kobayashi.

Eurekia angustifrons (Walcott).

Eurekia dissimilis (Walcott).

Eurekia granulosa Walcott.

Geragnostus brevis Palmer.

Idiomesus sp.

Leiocoryphe platycephala Kobayashi.

Plethometopus sp.

Pseudagnostus laevis Palmer.

Rasettia sp.

Richardsonella eurekensis Kobayashi.

Tellerina marica (Walcott).

Tostonia iole (Walcott).

G. A. Cooper (1948, written communication) of the U. S. National Museum writes that the Bullwhacker member

is easily recognized by its brachiopods. The Conodiscus is a circular shiny brown or black shell; the Westonia is like a Lingula but has parallel lines crossing the shell at about right angles to the long axis. The Elkania is another lustrous shell that looks like a small clam and was so mistaken by Walcott.

Cooper has identified the brachiopod Homotreta eurekensis (Ulrich and Cooper), Elkania hamburgensis (Walcott), Westonia iphis Walcott, Conodiscus burlingi (Kobayashi), and Xenorthis n. sp., from the member.

At Ninemile Canyon in beds equivalent to the Catlin member, Merriam found abundant agnostid trilobites and Desmetia cf. annectans (Walcott). Limestones above the upper gray Caryocaris shale of the Windfall at this locality, although resembling the Bullwhacker member at Eureka, yielded Kainella at an horimon 250 feet above the top of the shale and are accordingly assigned to the Lower Ordovician. In the Antelors Range the 
Bullwhacker type of lithology thus extends across the systemic boundary.

\section{ORDOVICIAN SYSTEM}

At the time of Hague's and Walcott's field work in the Eureka district the Ordovician had not been accepted as a separate system; the three formations which they defined, and which are now known to include sedimentary rocks of Ordovician age, were all assigned by them to the Silurian. The original descriptions of the upper and lower of the three formations indicate that the presence of several faunal and lithologic zones was recognized in both of them, and Walcott himself initiated the restudy and redefinition of the units by splitting off a separate formation, the Goodwin, from the base of the lower, or Pogonip, formation (Walcott, 1923 , p. 466-467).

The restudy of the Ordovician stratigraphy and paleontology of the Eureka district, and that of the Great Basin as a whole, has been an attractive field, and many individuals and groups have been active in it in recent years. Significant contributions to a more adequate knowledge of the section have resulted, which have materially changed our previous ideas. Our present concept of the Ordovician may be summarized as follows:

1. Of the three "Silurian" formations of Hague $(1883,1892)$ the Pogonip, or lowest, formation is here redefined as a group, from which has been excluded the Windfall formation of Cambrian age. The Pogonip group, thus limited, includes three new formations, the Goodwin limestone, the Ninemile formation, and the Antelope Valley limestone. The Eureka quartzite, or middle formation, remains essentially unchanged. Finally, the lower portion of the highest formation (Lone Mountain formation of Hague) has been established as a new formation of Late Ordovician age and is called the Hanson Creek formation.

2. A unit, unrecognized by Hague and Walcott and defined as the Vinini formation by Merriam and Anderson (1942, p. 1693-1697), is contemporaneous with a considerable part of the Ordovician sequence at Eureka as it was originally defined. It has been brought into contact with the Pogonip group and the Eureka and Hanson Creek formations by a very large thrust fault.

These changes in large part stem from the recognition that there are orderly facies changes in the Ordovician sedimentary rocks, which when distinguished cast light on the geologic history of the province and on the factors that controlled the localization of its mineral and petroleum concentrations.

The existence, within a few miles northwest of Eureka, of a western facies (Vinini formation) in the
Ordovician, so close to an eastern one made up of the redefined units of the original Eureka report, presents two major problems. One concerns the factcrs that led to the deposition of two such dissimilar contemporaneous stratigraphic sequences, the other the means by which the two have been brought into contret with one another.

The second problem has been solved by the dircovery in the Roberts Mountains area by Merriam and Anderson (1942, p. 1701-1702), and later in adjoining areas by others, of a major thrust fault, along which the Vinini rocks have moved eastward a distance probably measured in tens of miles. Actually, Kirk in 1933 (p. 31-32) predicted this solution, although he did not actually discover the thrust.

Solution of the first problem will probably require considerably more mapping in central Nevads. The presence of an unconformity at Cortez and in the Roberts Mountains, along which Lower Ordovician rocks are absent, could be interpreted as meanin $\%$ either that a barrier rose in that area in the Early Ordovician that resulted in the formation of two separate seas, or that elevation in Middle Ordovician time resulted in the removal by erosion of the sediments that were transitional between the two facies.

At present the first of these two alternatives appears somewhat more probable, for the reason that westward from Eureka the sedimentary rocks both in the Pogonip group and in the Eureka quartzite seem to show progressive changes-thinner bedding, a somewhat higher proportion of clastics in the carbonate rocks, and a replacement of massive dolomitic rocks by thinner bedded limestones - that might be interpreted as indicative of an approach to a low-lying land barrier rather than as suggesting a gradation to the chert, slate, and quartzite sequence that is characteristic of the Vinini formation.

\section{FASTERN FACIES POGONIP GROUP GENERAL FEATURES}

The name "Pogonip" has had a long history during which it has had varied meanings. It was originally defined by Clarence King in the course of the work of the 40th Parallel survey (King, 1878, p. 188) as including all the sediments between what was later called the Prospect Mountain quartzite of Early Cambrinn age and the Eureka quartzite of Middle Ordovician age. The type locality was on Pogonip Ridge ${ }^{7}$ in the White Pine or Hamilton District, some 30 miles soutl east of Eureka, a region recently studied by Humphrey (1956)

\footnotetext{
7 On the Pancake Summit and Green Springs 15-minute topographic çuadrangles of the U. S. Geological Survey, the Pogonip Ridge of King's usage is shown as Mount Hamilton of the White Pine Range.
} 
in which the rocks are metamorphosed by intrusives and disturbed by faulting.

Hague (1883, p. $260 ; 1892$, p. 48-49) redefined the Pogonip by including only the sedimentary rocks between the Dunderberg shale and the Eureka quartzite, and the name was used in this sense in the Eureka district and adjoining areas for many years. Both Hague and Walcott, however, recognized that these boundaries resulted in the inclusion in the basal Pogonip of beds containing a fauna closely related to higher Cambrian faunas elsewhere, and in 1923 Walcott (p. 466-467) proposed that the lowermost 1,500 feet or so of the Pogonip be separated and called the Goodwin formation. Walcott's suggestion, however, in the light of our present interpretation of Cambrian and Ordovician faunas, would have included in the Goodwin a greater thickness of low Ordovician rocks than of high Cambrian.

Partly because of this, and partly because Walcott made no effort to use the Goodwin for a mappable unit, the name did not have wide acceptance and use, although the restriction of Pogonip to the Ordovician strata seems to have been tacitly assumed by some recent workers, such as Sharp (1942, p. 657). An alternative procedure, however, resulted in the elevation of the Pogonip, with the inclusion of both Cambrian and Ordovician sedimentary rocks, to group rank (Merriam and Anderson, 1942, p. 1683). Finally, following detailed stratigraphic work, L. F. Hintze (1949; 1951, p. 11) and Easton and others (1953, fig. 2) proposed that the Pogonip be considered as a group, to include only the Ordovician portion of the unit.

We have accepted this and propose for the revised Eureka section the use of Pogonip group for the sedimentary rocks lying between the Cambrian Windfall formation, as here defined, and the Eureka quartzite. Merriam (1956) in the Antelope Valley region just southwest of Eureka, has distinguished three formations in the Pogonip group, and we believe that these units could be recognized and mapped in the Eureka area as well. Hintze (1951) distinguished six formations in the Pogonip group of western Utah, but we have not been able to use them as mappable units in the vicinity of Eureka, possibly in part owing to the relatively poor exposures of the Pogonip group that are prevalent there. It is probable that in many places in the Great Basin either local formational names will be needed in mapping the Pogonip or the group will have to be shown as undifferentiated, a course that has been followed in the mapping of the Eureka mining district quadrangle. The original mapping had largely been completed before Merriam's work in Antelope Valley was available, and an unjustifiably large amount of time would have been required to remap the Pogonip because of the prevailing poor exposures and complex structures.

As thus defined, the Pogonip group is a fairly easily recognized unit in the Eureka region. It is composed dominantly of limestone and thus contrasts with the dolomites that are so characteristic of much of the section above and below. The upper contrct with the Eureka quartzite, which is easily recognized, appears, as noted below, to be an unconformity. The lower contact with the Windfall formation on the east side of Prospect Ridge at Eureka exhibits a sharp lithologic boundary between the thin-bedded platy limestones of the Windfall below and the massive gray limestones with abundant gray chert above. This lithologic boundary, which is readily mapped, apparently does not coincide precisely with the paleontolog:c boundary between the Cambrian and Ordovician. Messrs. Bridge, Cooper, Cloud, and Palmer, who have all made collections along this boundary, agree that a fauna with elements of the highest Cambrian continues upwards about 20 feet into the Pogonip.

Relationships in Antelope Valley differ somewhat. Here beds lithologically like the upper or Pullwhacker member of the Windfall formation appear above the upper gray shale member of the Windfall at Ninemile Canyon and persist upwards through a graater thickness than at Eureka; the Kainella fauna, typical of the lowest Ordovician, occurs in these strata well below the massive chert-bearing limestones that, near Eureka, mark the base of the Pogonip group. We have not yet done detailed mapping in this area.

The three formations established by Merriam (1956) in the Antelope Valley area are as noted above consistent with our recent work close to Eureka. The three are the Goodwin limestone, the Ninemile formation and the Antelope Valley limestone. Both the Goodwin and the Antelope Valley are rather massively bedded limestones that contain chert locally; the Ninemile is composed of limy shale and shaly limestone that is less resistant to weathering and commonly forms a linear depression between the two belts of limestone. There is also normally a color contrast between the Ninemile and the other two units: the Ninemile weathers as a distinctly brownish or reddish-brown band, in contrast to the gray or gray-blue shades assumed by the limestones.

Hague (1892, p. 49) measured 2,700 feet of Pogonip strata near Eureka and estimated that there were about 3,000 feet at Wood Cone. If allowance is made for the 650 feet of beds now assigned to the Windfall formation, these figures are not greatly in excess of the 1,600 feet that we believe to be present in the somewhat faulted section in Goodwin Canyon and the 1,950 feet measured on the north side of Windfall Canyon. 
These thicknesses are, however, appreciably less than those reported from nearby areas to the south and east. Hague (1892, p. 49), for example considered that there were 5,000 feet of beds in the White Pine (Hamilton) district, and Sharp (1942, p. 650), measured 3,650 feet in the Ruby Range. Meriam (1956), moreover, has determined a total of about 3,000 feet on either side of Antelope Valley.

The lesser thicknesses found at Eureka possibly reflect increasing proximity to the "high" that is believed to have existed to the northwest at Roberts Creek Mountain and Cortez.

\section{AGE AND CORRELATION}

As now defined, the Pogonip group may range in age from earliest Ordovician to Chazy or Middle Ordovician. A number of faunal zones can be recognized in it, as will appear in the discussion of the three formations that compose the group in the vicinity of Eureka.

The faunal and lithologic evidence indicates strongly that there is a gradational contact at Eureka between the Cambrian and Ordovician sedimentary rocks and hence suggests that deposition continued without interruption from one system to another. This appears to be consistent with observations made at this contact in adjoining areas in Nevada (Sharp, 1942, p. 657) and southern California (McAllister, 1952, p. 11-12), but is in contrast with the unconformity reported in areas to the east (Richardson, 1913, p. 408; Gilluly, 1932, p. 18-20; Nolan, 1935 , p. 14-15). The evidence from the Nevada and southern California areas may perhaps be interpreted as indicating that the Cambrian and Ordovician sea was restricted to a relatively narrow width at the end of the Cambrian, but never actually was expelled from the central Great Basin.

In contrast, the upper contact of the Pogonip group with the Eureka quartzite is unconformable. Although Hague (1892, p. 56) remarked on the abrupt change in sedimentation at this bondary, he made no specific mention of an erosional break. This seems to have been first suggested as a possibility by Kirk (1933, p. 31). Merriam and Anderson (1942, p. 1683-1684) also noted the absence of higher Pogonip strata beneath the Eureka on Roberts Creek Mountain, the area at which Kirk reported the possibility of an unconformity; they also called attention to the section at Cortez where the Eureka rests on beds believed by James Gilluly (oral communication) and ourselves to be Hamburg dolomite. Recent study of the PogonipEureka contact at Western Peak, a northwest salient of Roberts Creek Mountain, indicates that the Pogonip group is represented here by only about 350 feet of the Goodwin limestone, disconformably overlain by Eureka quartzite. The mapping at Eureka has show" a similar situation, though on a smaller scale. Ther 3 are, for example, several tens of feet of beds above the Receptaculites zone below the quartzite on McCoy Ridge, whereas the quartzite rests directly on this zor 9 on the eastern flank of White Mountain, at the southwestern corner of the Eureka mining district quadrang'e.

\section{GOODWIN LIMESTONE GENERAL FEATURES}

For the lowest formation in the Pogonip gooup, we propose the name Goodwin limestone. This name should replace Walcott's Goodwin formation (Walcott, 1923, p. 466-467), which as originally defined included the beds now assigned to the Windfall formation. The restricted Goodwin limestone is well exposed on either side of Goodwin Canyon just east of hill 7708 of the Eureka mining district quedrangle, which may be taken as the type locality. JHere the formation rests upon the platy limestones of the Bullwhacker member of the Windfall formation just east of the summit of hill 7708 , and the overlying shaly limestone beds of the Ninemile formation may be seen beneath and to the southwest of the cemented gravel on the low divide east of the tunnel at elevation 7239 .

At Eureka the Goodwin limestone can be recognized, both lithologically and faunally, from nortl of the Bullwhacker mine discontinuously to the vicinity of the Jackson mine, and from there as a continuous band into Secret Canyon. It is probably present also in the area of folded and altered Pogonip rocks that lie above a steep thrust along the base of the ridge just west of Prospect Peak. The unit probably is present in the area of Pogonip outcrops mapped by Hague as extending southeast from Wood Cone, but we have not as yet restudied this region. The Goodwin limestone also occurs on either side of Antelope Valleт, as recently described by Merriam (1956).

The Goodwin limestone at Eureka can be generally described as composed dominantly of well-bedded, fairly massive limestone that is light gray to klue gray in color. Local platy limestones occur, but they are relatively much less abundant than in the beds above and below. Light-gray to white chert is common in the lower 350 feet of the unit, but decreases in amount in the higher beds. Much of the limestone is very fine grained or even aphanitic. Lumpy bedding surfaces are not uncommon, and many of the massive-appearing limestone beds show, on close inspection, irregular crinkly clay partings.

In the Antelope Valley areas the greater part of the formation as distinguished by Merriam is composed of massively bedded limestones with gray and white chert, interbedded with thinner-bedded limestones. 
It is thus similar to the sequence at Eureka. The basal several hundred feet of the unit, however, as noted above, resembles the Bullwhacker member of the Windfall formation in lithologic character, though containing a fauna characteristic of the Goodwin.

We have not been consistent in our solution of this conflict between lithologic and paleontologic evidence in regard to the base of the Goodwin. At Eureka, where the two differ by a matter of only some 20 feet, we have adopted the lithologic boundary; but in the Antelope region, where there is a difference of several hundred feet, we have extended the Goodwin downward to include the Ordovician strata. The upper contact with the shaly beds of the Ninemile formation is sharp in the Antelope area but is less distinct at Eureka, where more massive beds occur within the Ninemile and where in areas of poor exposures they make determination of the boundary somewhat uncertain.

In both regions the massive limestones are locally irregularly dolomitized; the alteration appears to be due to hydrothermal activity, rather than to original sedimentary processes.

Because of the gradational nature of the boundaries, precise measurements of the thickness of the Goodwin limestone are not too meaningful. We have measured sections in Windfall and Goodwin Canyons at Eureka, and in Ninemile Canyon in the Antelope region. At the two Eureka localities the unit ranges from 900 to 1,100 feet in thickness, and at Antelope it is about 1,650 feet. This section, however, includes more than 600 feet of platy limestone at the base that is lithologically, though not faunally, similar to the Bullwhacker.

\section{AGE AND CORRELATION}

A large number of fossil collections have been made from the Goodwin limestone in recent years by paleontologists of the Geological Survey and the National Museum. Most of them have been made at Eureka, but some have come from the Antelope Valley area. The late Josiah Bridge, of the Geological Survey, and G. A. Cooper, of the National Museum, made most of the collections and have prepared reports on the fauna. Their reports are in close agreement and indicate that two faunal zones can be recognized, the lower of which can be further subdivided into two subzones.

Concerning the lowest subzone, designated as $a^{\prime}$, G. A. Cooper (1948, written communication) writes that it is

Often of dark granular limestone, moderately thin bedded or lighter massive limestone containing a small species of Symphysurina and a species of Obolus in abundance.

Fossils identified:
Brachiopods:

Obolus anceps Walcott.

Homotreta sp.

Lingulella sp.

Trilobites:

Symphysurina eurekensis (Walcott).

S. spicata Ulrich.

New genus related to Eurekia.

I do not know if these fossils are earlier in deposition than those of Zone $a^{\prime \prime}$ or if they are contemporaneous. They were not collected in the long sequence at Windfall Canyon.

I am uncertain as to whether or not these roc's should be assigned to the highest Cambrian or the Ordovician. The new genus related to Eurekia is suggestive of the Caml rian but, on the other hand, it is a new trilobite related to $E$ irekia rather than a clear example of that earlier trilobite. Symphysurina spicata has been seen in association with other fossils of subzone $a^{\prime \prime}$ which I believe belong to the Ordovician. I believe that the subzone $a^{\prime}$ rocks are best assigned to the Ordovician although some uncertainty exists.

In regard to subzone $a^{\prime \prime}$ he writes:

Most of these localities include massive poorly bedded rocks although some limestone of distinctly bedded character occurs. The fossils are definitely related to those of subzone $a^{\prime}$ and two of the species occur in both zones.

Fossils identified:

Brachiopods:

Nanorthis cf. N. hamburgensis (Walcott).

Apheoorthis melita (Hall and Whitfield).

Plectotrophia sp. or Tetralobula sp.

Obolus anceps Walcott.

Glyptotrophia sp.

Homotreta sp.

Trilobites:

Symphysurina spicata Ulrich.

S. n. sp.

Eurekia-like new genus.

Correlation of subzone $a^{\prime \prime}$.-I regard this zone an of probable Ordovician age. The brachiopods occurring in it are an equivocal lot because the Apheoorthis occurs in definite Cambrian as well as rocks thought to be of Ordovician age. Nanorthis occurs in the Chushina, Mons, Manitou, lower Garden Cit;, and Grove limestones. These were called Upper Ozarkian by Dr. Ulrich but are generally placed in the lowest part of the Ordovician. This is certainly true for Nanorthis, which occurs in all of the formations listed above. As noted before, the Symphysurina is regarded as of Ordovician age. Nanorthis occur still higher with Leiostegium and Kainella, both definitely belcnging to the Ordovician. I should say, therefore, that zone $a^{\prime \prime}$ is best assigned to the Ordovician.

As mentioned above, the lower 20 feet or so of the Goodwin mapped in the Eureka area contains faunal elements usually regarded as indicating a Late Cambrian age. The actual Cambrian and Ordovician boundary therefore remains indefinite. Ir fact, this boundary should perhaps be viewed as a transition zone rather as occurring at a precise formational contact like that which separates the Windfall from the Goodwin.

Trilobites of the Eurekia type are the most important holdovers from unquestioned Windfall Late Cambrian 
into basal Goodwin. As listed by G. A. Cooper (1948, written communication) these trilobites from basal Goodwin subzones $a^{\prime}$ and $a^{\prime \prime}$ represent a new genus related to Eurekia. A. R. Palmer, on the other hand (1953, written communication) considers Eurekia itself to continue on into basal Goodwin. In view of such circumstances, not uncommon near the classic system boundaries, the basal 20 feet of the Goodwin as mapped at Eureka may properly be referred to as earliest Ordovician or latest Cambrian.

The higher Goodwin faunal zone, zone $b$, is also of Early Ordovician age. Cooper has identified the following fossils in this zone:

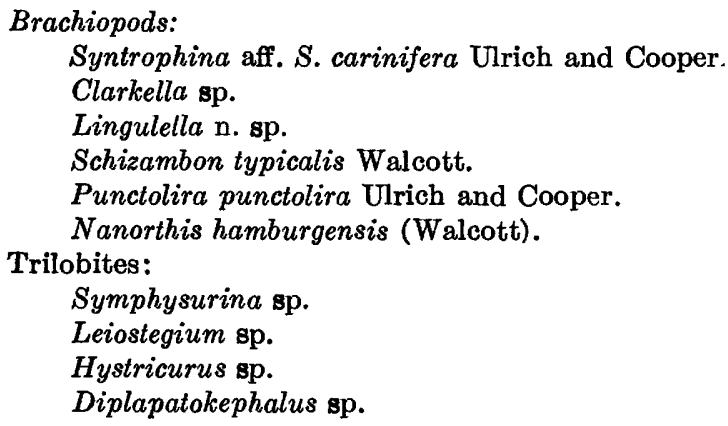

$\mathrm{He}$ considers that the collections from this zone might be further subdivided, though there is no question as to the Early Ordovician age of the collections, which he reports show relationships to the faunas of the lower Manitou, Garden City, Grove, Tribes Hill formations, and the Mons formation in Canada.

Merriam (1956) found the characteristic Lower Ordovician trilobite Kainella in the lower third of the Goodwin limestone in the Antelope sections; with it were found also Diplapatokephalus finalis and ?Nanorthis multicostata. The upper beds of the Goodwin at Antelope yielded a later fauna with Xenostegium belemnura and Nanorthis hamburgensis.

The collections from the Goodwin are believed to indicate an early Canadian age for the formation.

\section{NINEMHE FORMATION} GENBRAL FEATORES

The Ninemile formation is here named from Ninemile Canyon, on the west side of the Antelope Range near its north end. The formation is well exposed near the mouth of the Canyon, which has been chosen as the type locality. The unit can be recognized at Eureka in the band of rocks mapped as the Pogonip group from Goodwin Canyon south to Windfall Canyon, and it extends further south in this belt into the Secret Canyon drainage. We have not as yet studied in detail the Pogonip outcrops shown by Hague southwest of Prospect Peak in Spring Valley and the larger outcrop that extends southeast from Wood Cone, but it is probable that the Ninemile is present here. Merriam has also found the formation on the west side of Antelope Valley in the Monitor Range; here it occurs in the vicinity of Copenhagen and White Rock Canyons. We have not recognized the Ninemile in the Fioberts Mountains or at Cortez.

The Ninemile formation is composed of platy and thinly bedded fine-grained to porcellaneous limestone of medium gray color, which on fresh fracture exhibits an olive-green or greenish-blue cast. The shale and limy-shale partings likewise show this distinctive color. The unit also includes beds of light-gray crystalline sandy limestone; some are sufficiently arenaceous to be called limy sandstones. In Goodwin Canyon at Eureka some of the limestone beds are cherty.

Both the upper and lower contacts of the formation are gradational and, especially at Eureka, the formation boundaries are not easily established in detail The combination of distinctive coloration and dominantly thinner bedding is generally adequate for mapping purposes, except on large scales.

A characteristic feature of the unit is the abundance of fossil fragments that weather out from the limestone on bedding surfaces between limestone and shale interbeds. At Eureka the olive coloration of the freshly broken surface is modified to some extent by pale brownish or reddish colors assumed on weathering; the olive color for the formation as a whole, however, is characteristic, as it contrasts with the grayer color of the more massive limestones above and below. These thicker-bedded formations are also more resistant to weathering, with the result that the Ninemile formation commonly underlies saddles or valleys between the cliffy limestone outcrops of the Goodwin and Antelope Valley limestones.

The Ninemile formation appears to range in thickness from less than 200 feet to more than 500 feet in the Antelope Valley area, and the two sections measured at Eureka fall within these limits. At the type locality the unit is about 540 feet thick, and at $W$ indfall and Goodwin Canyons at Eureka there are approximately 300 and 400 feet, respectively.

\section{AGE AND CORRELATION}

The Ninemile fauna is one of the largest and best preserved of the Cordilleran Ordovician assemblages. It is characterized by Kirkella vigilans (Whittington), Hesperonomia antelopensis Ulrich and Cooper, Camerella sublaevis Ulrich and Cooper, and Archaeorthis elongata Ulrich and Cooper. Merriam (1959) has recognized at least 20 species, most of them as yet undescribed, in preliminary studies of his collections and anticipates that future study will add severs.l times that number.

The Ninemile fauna with various species of Tirkella has been widely recognized in North Americe from Greenland to the Cordilleran belt and southvrard to 
Texas (Kirk, 1934). In Utah it occurs in the upper Garden City (Ross, 1949, p. 480; 1951, p. 27) and in the Pogonip group as defined by Hintze (1951, p. 16-17). The fauna probably occurs also in the Ruby Range, the Hamilton district, the Ely district, and the Pioche district in Nevada, although we have not made collections from these places.

In terms of the Appalachian section and that in eastern Canada the Ninemile formation is of Beekmantown or late Canadian age.

\section{ANTELOPE VALIEY LIMESTONE GENRRAL FEATURES}

The Antelope Valley limestone is the uppermost formation in the Pogonip group and is here named from its occurrence in the Antelope Valley region. The unit is especially well exposed on Martins Ridge, a linear northward-trending ridge that separates Copenhagen Canyon from Antelope Valley and is about 25 miles southwest of Eureka.

The formation has been recognized by Merriam (1956) in both the Monitor Range and the Antelope Range on either side of Antelope Valley. It is present in the Eureka district also, although it has not as yet been mapped there. We have, however, recognized the formation in the outcrop of the Pogonip group from Goodwin Canyon south through Windfall Canyon; and the unit is believed to extend still farther south in the Secret Canyon drainage. The Antelope Valley limestone is also thought to be present in the undifferentiated Pogonip southwest of Prospect Peak and in the outcrop southeast of Wood Cone. In both of the latter areas Hague (1892, p. 52-53) reports collections of fossils that are characteristic of the formation.

The Antelope Valley limestone is composed dominantly of thickbedded or massive medium-gray or light-bluish-gray fine-grained limestone. Very little chert occurs in these beds, in contrast to the cherty massive limestones of the Goodwin. Cliff-forming units are not uncommon. Locally, thinner bedded zones are found, notably at the base of the formation on Martins Ridge, where there are about 150 feet of rather thinly bedded argillaceous limestone. Here the formation is not separable from the underlying Ninemile formation on the basis of a change from thinner bedded to thicker bedded limestone, but the color change in the thin-bedded rocks is distinctive, as is the faunal change.

Thinner bedded limestones are also found near the top of the formation both in Antelope Valley and at Eureka. In this part of the section the limestone tends to be flaggy or platy with tan argillaceous partings and mottlings, although the limestone still retains the medium-gray to light-bluish-gray color of the bulk of the unit.
The Antelope Valley limestone generally tends to form more rugged slopes as compared witl the underlying Ninemile formation, although it in turn, at Eureka, is overlain by the cliff-making Eureka quartzite. The limestone beds weather with rough surfaces, and the abundant fossils not infrequently are silicified and weather out in relief. As is also true of the Goodwin formation, the limestone beds are locrlly dolomitized, and at Eureka, in the vicinity of some of the mineralized areas, the limestone has beer irregularly converted to jasperoid. In other places cal cite veinlets are numerous.

The lower contact of the Antelope Valley limestone, as noted above, is gradational with the Ninemile formation; in the type area the formation is overlain by the Copenhagen formation (Merriam, 1956), but in the Eureka district proper the overlying formation is the Eureka quartzite. The contact at Eureka is an unconformity above which there has been either considerable erosion or nondeposition.

As a consequence, the thickness of tre Antelope Valley limestone varies considerably in the vicinity of Eureka. It is absent to the northwest, as at Roberts Creek Mountain, is about 400 feet thick close to Eureka, and attains a thickness of about 1,100 feet on Martins Ridge. Two sections were measured at Eureka, one in Windfall Canyon giving a thickness of 400 feet and the other, on McCoy Ridge on the east side of Goodwin Canyon, being 430 feet thick. On Martins Ridge Merriam divided the 1,100 feet measured into a lower 150-foot unit of thinner bedded limestones, a middle unit of 600 feet of massive and cliff-forming limestone, and an upper 350-foot unit of platy and flaggy limestone. Sharp's (1942, p. 658-659) measured section in the Ruby Range suggests that an even greater thickness of the Antelope Valley is present there.

\section{AGE AND CORRELATION}

Faunas of the upper Pogonip or Antelope Valley limestone have been extensively studied since the time of the original Eureka Survey. Hague $(1892$, p. 5253) recognized that the fauna of this upper portion of the Pogonip was distinctive and characteristic and cited a number of localities from which collections were made. In recent years Josiah Bridge and P. E. Cloud, of the Geological Survey, and G. A. Cooper, of the National Museum, have made large collections from near Eureka, and Merriam has collected both from here and from Antelope Valley. Several faunal zones have been distinguished as a result of this more recent work; some of them appear rather local, but others are widespread throughout the Eureka area.

The lowest or oldest zone is called by I Terriam the Orthidiella zone and appears to be best known in 
Antelope Valley, especially from the thin-bedded basal Antelope Valley strata in the narrows of upper White Rock Canyon in the Monitor Range. The assemblage here is large and diverse with such characteristic forms as Orthidiella striata Ulrich and Cooper, O. longwelli Ulrich and Cooper, Orthis sp., Pliomerops nevadensis Walcott, Pliomerops cf. barrandei (Billings), Ectenonotus cf. E. westoni (Billings), small Leperditias, and slender branching cyclostomate? bryozoa.

The next higher zone is characterized by the genus Mitrospira. It is found both at Eureka and in the Antelope Valley exposures, where at some localities the limestones are crowded with Mitrospira longwelli Kirk and subordinate Maclurites, both attaining large size. This is also the zone in which Receptaculites mammillaris Newberry occurs. The widespread Receptaculites facies of the Cordilleran Pogonip is probably in the main limited to the Mitrospira zone; Bridge (written communication) and Cooper (written communication), in fact, have suggested that a separate faunal zone be established for it, although the genus is not restricted to the Pogonip but continues on into the Middle Devonian. The beds in this zone are in many places crowded with $R$. mammillaris and $R$. elongatus. These fossils are especially common at McCoy Ridge, where, however, they are now thought to range upwards into a higher zone.

A third faunal zone has been recognized by Bridge and Cooper at Lone Mountain, on White Mountain southwest of Prospect Peak, and in Ratto Canyon near the Oswego mine. This is characterized by the brachiopod, Desmorthis. The zone appears not to be present in the main Eureka district or in Antelope Valley.

The highest and youngest faunal zone, the Anomalorthis zone, is again widely distributed, being found at a number of localities in the vicinity of Eureka, as well as in Antelope Valley. It appears to be especially well dereloped on McCoy Ridge just below the Eureka quartzite. The abundant fauna has locally been preserved by silicification; certain beds are crowded with small, high-spired gastropods, orthoid brachiopods, leperditian ostracods, hemispherical stony bryozoa, and abundant cystid plates. A few of the commoner forms of the large fauna are: Anomalorthis nevadensis Ulrich and Cooper, A. lonensis (Walcott), Orthis sp., Pliomerops sp., and Leperditia cf. bivia White. Some beds contain numerous centrically laminated algal nodules, which are generally assigned to Girvanella, and Bridge has suggested that this be recognized as a separate faunal zone.

The Antelope Valley faunas are correlated with the Chazy of the eastern United States. Beds of this age are probably present also in the upper portion of the
Pogonip sections east of Eureka in the Ruby Pange, Hamilton and Ely districts, but we have no firsthand knowledge of the thickness or detailed litr ologic character of the equivalent beds at these places. Similarly, comparable faunas are reported from the upper Pogonip in the Nopah Range (Hazzard, 1937, p. 323) and from the Quartz Spring area (McAllister, 1952 , p. 11) of southern California. The unit is probably equivalent faunally also to the Juab limestone, Kanosh shale, and Lehman formation, as defined by Hintze (1951, p. 17-20).

\section{EUREKA QUARTZITE GENERAL FEATURES}

The name Eureka quartzite was proposed by Hague (1883, p. $262 ; 1892$, p. 54-57) for a prominent white quartzite which underlies much of the surface in the vicinity of Eureka. Within the area mapped by Hague, which seems to have been collectively considered by him as the type locality, the formation is everywhere thoroughly fractured or brecciated because of extensive faulting; and in many places it has been recrystallized as a result of mineralizing solutions. In the Eureka district, consequently, the relationships of the formation to the adjacent map units are commonly poorly exposed; and the lithologic character of the formation itself is not typically shown. In some places extensive faulting or alteration led Hague to map other silica-rich rocks as part of the Eurel-a; on Hoosac Mountain for example, part of the unit mapped as Eureka is actually silicified fossiliferous Permian(?) limestone, and southeast of Eureka some outcrops of quartzite belong to Oxyoke Canyon member of the Nevada formation were similarly assigned to the Eureka.

Kirk (1933, p. 34) recognized the inadequacy of the outcrops in the Eureka district proper and proposed that the well-exposed section along the west base of Lone Mountain be chosen as a new type locality. The redesignation has been accepted by the Geolngical Survey; and the Lone Mountain section, which is about 15 miles airline northwest of Eureka, seems now to be generally regarded as an appropriate standard sıction for comparative purposes.

G. W. Webb ${ }^{8}$ (Hintze and Webb, 1950) has resently reviewed the relationships of the Eureka quartzite, but his conclusions have not as yet been pubrished completely.

In the immediate vicinity of Eureka the quartzite is discontinuously exposed from Caribou Hill, about a mile west of the town, through McCoy Ridge, Windfall Canyon, and Hoosac Mountain south to the east flank of Roundtop Mountain, near the mouth of Secret

\footnotetext{
8 Webb, G. W., 1949, Stratigraphy of the Ordovician quartzites of the Great Basin Unpublished thesis on file at Columbia University, New York.
} 
Canyon. Much more extensive exposures were mapped by Hague west and southwest of Prospect Peak. In this area, which has been only partially restudied, the outcrops of the Eureka lie above, or close to, a thrust fault along which Ordovician rocks have overriden Cambrian strata to the north and Devonian sedimentary rocks, including the Devonian Oxyoke Canyon sandstone member of the Nevada formation, to the south.

In addition to the occurrence on Lone Mountain we have examined and locally mapped masses of Eureka quartzite in Roberts Creek Mountain, on either side of Antelope Valley, and as isolated masses along the road from Eureka to Mount Hope.

The Eureka quartzite is typically a vitreous gleaming-white sugary quartzite of fine to medium grain. Except for surficial limonitic coatings the rock usually shows few impurities. Thin sections of the rock show well-rounded quartz grains, clear except for abundant fluid inclusions; the grains are now cemented by quartz in optical continuity with that forming the original sedimentary particles. Only rarely does the formation contain poorly cemented or sandy beds; these may occur locally near the bottom or top.

Kirk (1933, p. 27-28) distinguished three divisions of the quartzite at most of the localities he studied. One of these, only a few feet thick, he believed to be the basal bed of the overlying formation, not to be properly included in the Eureka. Where we have recognized this, we have included it in the Hanson Creek formation. Kirk's second division is the thickest and most widespread unit. It is composed of typical white vitreous quartzite and is normally a cliffmaker. It contrasts especially in color with the lowest division (commonly about one-third of the total thickness), which is reddish brown or brown on weathered surfaces and normally shows better bedding and in many places a characteristic crosslamination.

Normally the Eureka is easily distinguished from other quartz-rich formations: the Prospect Mountain quartzite is much darker in color, is less well sorted, contains shaly or pebbly interbeds, and weathers to small joint blocks; the quartzite in the Oxyoke Canyon sandstone member of the Nevada formation commonly is interbedded with dolomite and in most places contains a moderate amount of dolomite as cementing material in addition to silica. The quartzites in the Carboniferous formations, in addition to being darker and less pure, are interbedded with conglomerates, shales, and chert-pebble-bearing limestones. Adjacent to igneous rocks or mineralized areas, or in regions of intensive brecciation or faulting, these distinctions may disappear, and in places it is difficult to separate the Eureka-which in such an environment crops out as an aggregation of large rounded masses of textureless silica rock, in which neither individual gr ins nor bedding can be recognized - from similarly altered masses of other formations. In such places the stratigraphic relations of the beds are the only satisfactory means of identification. Hague has reported that near McCoy Ridge brecciated and altered Eureka quartzite contains 0.1 ounce of gold per ton and was quarried as a flux for the local smelters.

Over most of the area we have studied the contact between the Eureka quartzite and the limestones of the underlying Pogonip group is sharp, though not uncommonly it is concealed by talus from the more resistant Eureka. South and southwest of Lone Mountain, however, Kirk (1933, p. 28, 30, 32-34) and Merriam (Merriam and Anderson, 1942, p. 1684-1685; Merriam, 1956) have reported the presence of a sequence comprising a lower sandstone overlain by calcareous shales and sandstones and sandy limestones in the interval occupied by the lower division of the Eureka farther east. The contact with the Pogonip in these places is as a result much less striking. At Lone Mountain, for example, Kirk describes 50 feet of brownish-weathering sandy dolomite between typical Pogonip and vitreous Eureka; and on either side of Antelope Valley he and Merriam have found 200 to 300 feet of fossilferous beds that Merricm (1956) has described as a separate formation, which is equivalent to Kirk's lowest division of the Eureka.

The upper boundary of the Eureka is also in most places abrupt, dark limestones or dolomites of the Hanson Creek formation resting directly on the quartzite. Kirk, however, as noted above, considers that locally at least there are a few feet of snndy beds at the contact that should be assigned to the basal part of the Hanson Creek, and Merriam (1910, p. 10-11; 1942 , p. 1084) reports in the Roberts Mountains

a zone in which the Eureka tends to lose much of its dense vitreous character and in which there appear patches of poorly consolidated sand. Where this condition first appears there does not seem to be a single discrete bed of the sandy material but rather an irregular, patchy distribution of this phase within the denser quartzite.

Areally, however, the evidence seems clear that there are unconformities at both contacts of the Eureka quartzite. The presence beneath the Eureka of probable Hamburg dolomite at Cortez, Goodwin limestone on Western Peak in the Roberts Mountains, and varying horizons of the Antelope Valley limestone at Eureka clearly indicate a significant time break prior to deposition of the Eureka sands. Hague (1892, p. 56-57) first called attention to the unconformity at the top of the Eureka quartzite, although the area which he cites as providing evidence of the break is structurally complex and may not provite convincing 
proof. More convincing evidence is provided by the fact that, followed from Eureka, Nev., east and northeast into Utah, the Hanson Creek formation and its correlatives rest upon strata ranging from beds low in the Ordovician, as at Gold Hill, Utah (Nolan, 1935, p. 15), to the highest beds of the Eureka quartzite. At Roberts Creek Mountain, however, Merriam (1940, p. 10) noted that there did "not appear to be clear-cut evidence of post-Eureka stripping in the form of an erosion surface."

We found no satisfactory place in the immediate vicinity of Eureka to determine the thickness of the formation. Hague (1892, p. 57) estimated the thickness to be about 500 feet and gives a partial section near Castle Mountain east of Wood Cone totaling 300 feet. Merriam measured 350 feet at Lone Mountain and nearly 500 feet on the northwest side of Roberts Creek Mountain (1940, p. 1684). Kirk (1933, p. 30) reports that measured sections of the Eureka quartzite within a radius of 50 miles of Eureka range between 225 and 300 feet. Sharp (1942, p. 659), however, found the Eureka absent in the Ruby Range, not far beyond this distance.

\section{AGE AND CORRELATION}

There is no direct fossil evidence for the age of the Eureka quartzite in the Eureka district itself, although the upper Chazyan age of the highest Antelope Valley limestone strata and the Richmond age of the overlying Hanson Creek formation fairly well limits the possible age assignment. The faunas collected in the calcareous beds below the vitreous quartzites by Kirk in the Antelope Range and by Merriam in the Monitor Range are regarded by Kirk (1933, p. 42) as of approximate Black River age and by Merriam as indicating Black River to Trenton; if the beds from which these collections were made are actually a facies of the lower division of the Eureka, these fossils would fix its age locally with a fairly high degree of precision. Kirk seems to have considered that the vitreous middle division of the Eureka might be somewhat younger and suggested a correlation with the lower part of the Bighorn dolomite. This dolomite he believed to be of pre-Maysville, post-Trenton age and to represent a stratigraphic unit not present in the eastern United States. Merriam has suggested that there is little real evidence that the Eureka is actually a marine deposit; he concludes that it may be indicative of a widespread and protracted emergence during Mohawkian and Cincinnatian time with restricted marine embayments which received sediments such as those found in the calcareous beds in the Antelope and Monitor Ranges.

Kirk (1933), Hintze (1949, 1951), Hintze and Webb (1950), and Webb ${ }^{9}$ have made extensive studies of the
Eureka quartzite and related formations and have suggested detailed correlations of the unit over much of the Great Basin. Recent work has shown that Kirk was misled by some of the earlier published record and hence reached conclusions, concerning the source of the sands, that now are believed to be incorrect. He postulated, for example, a broad embayment near the Frisco district in Utah, which was supplied with detritus from the north and east, based on a supposed thickness of the Eureka at Frisco of 2,000 to 2,500 feet. These beds, however, are now assigned to the Lower Cambrian (Nolan, 1943, p. 151; Hintze, L. F., 1949, p. 48-49), and it is unlikely that the embayment and its supposed source of sediments existed.

Kirk also accepted estimates by Ball (1907) of considerable thicknesses of Eureka quartzite centering in the region between Beatty and Goldfield in southern Nevada which had been supplied from a source in the south or southwest. Although no recent detailed stratigraphic work is known to have been done in the areas cited by Ball, the thicknesses of the Eureka found by McAllister (1952, p. 12-13) to the west, Hazzard (1937, p. 324-325) to the south, and C. R. Longwell (oral communication) to the east and southeast surgest that Ball's identification of the Eureka may have been faulty.

L. F. Hintze (1951) and Hintze and Webb (1950) have worked mostly to the east of Eureka in eartern Nevada and Utah and have added to the data presented by Kirk, on the distribution of the Eureka in wertern Utah. Together with Ross $(1949,1951)$, they have also shed light upon the relationships of the Eureka quartzite to the Swan Peak formation of central and northeastern Utah. The Swan Peak is similar lithologically to the Eureka and occupies a similar stratigraphic position to it, between Lower and Upper Ordovician sedimentary rocks. The Swan Peak, however, recently has been shown to contain the Anomalorthis fauna of the upper Antelope Valley limestone and hence to be older than the Eureka. This conclusion has been checked by the discovery of a section at Ibex, Utah (L. F. Hintze, 1951), where both quartzites are found separated by 85 feet of dolomite that contains a coral fauna correlated with one found by Kirk at the base of the sandy and limy zone lying above the Pogonip group in the Antelope Range. The Swan Peak, according to Webb (in Hintze, 1951, p. 21) is a regressive sandstone that thins in western Utah and disappears in Eastern Nevada; it grades into successively younger zones of the Pogonip as it is traced westward.

\footnotetext{
- Webb, G. W., 1949, Stratigraphy of the Ordovician quartzites of the Great Basin: Unpublished thesis on file at Columbia University, New York.
} 
The precise dating of the Eureka quartzite and its relationships to other Ordovician formations is of considerable interest because of the light it may shed on the structural history of the Great Basin during Ordovician time. The stratigraphic evidence indicates, as noted on a previous page, that there were two quite different sedimentary facies deposited in Nevada in Early Ordovician time, and we believe that the relationships at Cortez, northwest of Eureka, suggest that they were laid down in two sedimentary basins separated by a "high" or positive area that came into existence towards the end of the Cambrian and was completely overlapped in the Middle Ordovician by the sands that now constitute the Eureka quartzite.

On the other hand, to the northeast of Eureka (Sharp, 1942, p. 659; Nolan, 1935, p. 16) the Eureka itself is absent, and Upper Ordovician strata rest directly on equivalents of the Pogonip group, the faunal evidence (Ross, 1951, p. 33-36) suggesting that an Early Ordovician seaway extended over all of this area. The Pogonip group sediments deposited in such a seaway appear, however, to have been in part removed by erosion during an uplift in Middle Ordovician time. There thus seems to have been an earlier barrier northwest of Eureka that was high enough and persistent enough to permit the deposition of two very different sedimentary facies on either side of it in Early and perhaps early Middle Ordovician time and a later one to the northeast of Eureka that accomplished only the erosion of some of the recently deposited Pogonip sediments before it too was overtopped by the late Ordovician Hanson Creek sea.

We do not at present have enough data to determine whether or not the two barriers were entirely fixed in position and completely separated in time or whether they represent a single swell (Schuchert, 1923, p. 165) that progressed from west to east during Early Ordovician time. Neither do we know enough to account for the difference in behavior of the two barriers-the one resulting in two different sedimentary facies, the other simply accomplishing erosion of recently deposited sediments.

A speculative answer, which seems to accord with the present known facts, would be that the two barriers were separate in time and space, that they were linear north or north-northeastward trending swells that arose from the floor of the Cordilleran geosyncline successively during the Ordovician and that they differed in the sedimentary record on either side of them because the earlier and more westerly one was higher above sea level and extended farther to the south. In the latitude of Eureka the seaways on either side of this western swell, though probably connected to the south, received very different sediments from the barrier itself and from the borderlands beyond. The more easterly and younger barrier under this hypothesis terminated southwards about in the latitude of Eureka. Here it was broad and low, and its chief effect in this region was the erosion of the Pogonip rocks. Possibly at some distance farther north we might expect future work to show different sedimentary facies of Middle Ordovician age on either side of it.

\section{HANSON CREEK FORMATIO ${ }^{*}$ GENERAL FEATURES}

The Lone Mountain limestone, as orizinally defined by Hague $(1883 ; 1892$, p. $57-62)$ contained two distinctive faunas, which he designated as of Trenton and Niagaran age, and which, locally at least, he described as occurring in rocks that were lithologically distinct. The sediments of supposed Trenton age were subsequently found to have a very widespreed distribution over the western Cordilleran region and to be actually of Late Ordovician age (Kirk, 1933, p. 30). Formation names were assigned to these beds elsewhere, but none was used for the Eureka section until Merriam (1940, p. 10-11) proposed the name Janson Creek formation for the beds between the Eureka quartzite and a newly defined Roberts Mountains formation of Silurian age. The type locality was selected as the main or north fork of Pete Hanson Creek on the northwest flank of Roberts Creek Mountain, about 35 miles northwest of Eureka and 20 miles north of Lone Mountain. The name has been generally accepted and used by recent workers in central Nevada geology.

Beds probably assignable to the Hanson Creek formation in the immediate vicinity of Eureka are found from a short distance south of Eureka along the east side of McCoy Ridge in New York Canyon; small outcrops also occur on the northeastern sfur of Hoosac Mountain and in the saddle connecting Prospect Peak and White Mountain. Hague also mafned considerable areas of "Lone Mountain limestone" east and southeast of Dry Lake, in the hills connerting the Fish Creek Range and Prospect Ridge, and north of Wood Cone. Of these we have examined only the Wood Cone locality in any detail; this is the loc-lity at which Hague collected the "Trenton" fossils on which he based his age assignment of the basal Lone Mountain. The formation is also of course well shown on Lone Mountain and in the Antelope Valley s.rea, where it has been mapped by Merriam.

Two quite different lithologic types characterize the Hanson Creek formation. The exposurer near Eureka are all of a dark-gray to black dolomite and are all intensely fractured and brecciated by reason of their proximity to faults of large throw. The Lone Moun- 
tain section is also largely dolomite, though not deformed as at Eureka; but the Wood Cone occurrence contains considerable amounts of limestone, and those in the Roberts Mountains and Antelope Valley are almost entirely of limestone and calcareous shale.

The replacement of dolomite in the Hanson Creek sequences by limestone as the formation is followed westward is paralleled in other middle Paleozoic formations. Although there has undoubtedly been some telescoping of sections because of thrust faulting, the change from dolomite to limestone westward is thought not to be the result of major crustal shortening such as has caused the dissimilar eastern and western facies of the Ordovician to be in contact with each other. Rather, it is probable that the change to limestone reflects an approach to a recurrently emergent region; carbonate rocks that were deposited in such seaways were not subject to the long continued reworking in a marine environment which is thought by some to be a major factor in the formation of penecontemporaneous dolomites.

Merriam (1940, p. 11) has described the formation at the type locality as follows:

Kirk (1933, p. 28-31), who has studied the Eureka in this region, calls attention to a thin layer of saccharoidal sandstone resting upon a somewhat uneven surface of dense quartzite. The thin sandstone is regarded by Kirk as the initial deposit of the overlying Upper Ordovician herein named the Hanson Creek formation. Whatever the case may be, it is evident that toward the top of the Eureka there is a zone in which the Eureka tends to lose much of its dense vitreous character and in which there appear patches of poorly consolidated sand ... This ... gives way to ... lime-cemented or loose sandstone followed by very dark-gray dolomitic limestones, found in place 10 to 15 feet above unquestionable Eureka quartzite. This, the lowest calcareous member of the Hanson Creek, is a darkgray to blackish, medium-grained, poorly stratified dolomitic limestone containing scattered small crinoid stems and irregular calcite veins. This lower division has a thickness not over 40 feet at the type section. It grades upward into a very finetextured, poorly bedded, noncrinoidal, medium- to dark-gray limestone, with many calcite veinlets and small black chert nodules. The thickness of this member is about 45 feet. Above follows 140 feet of thin-bedded, slabby and shaly limestone, dark bluish gray when fresh, but weathering to a very light gray. This part of the section is very fossiliferous, . . . [with a] fauna with little doubt the same as that reported by Hague (1892, p. 59) from the "Trenton" portion of the "Lone Mountain limestone" northeast of Wood Cone in the Eureka district . . . In the succeeding 140 feet, . . . the stratification of the dark-gray limestone is less well defined. From [this zone] upward for 180 feet to the base of the black chert which defines the top of the formation, the limestone is quite massive, very dark gray, and fine-grained.

At Wood Cone and in the Monitor Range the unit is prevailingly a thin-bedded platy to flaggy limestone with, in the Monitor Range, accompanying calcareous shales. Light-bluish-gray weathering is characteristic of the limestones, and where the limestone is slightly argillaceous, as at Wood Cone, the weathered surfaces may be striated or mottled with tan.

The Hanson Creek formation at Lone Mountain, is largely medium- to dark-gray dolomite and dolomitic limestone; the bedding is thicker than in the limestone phase of the formation, and the texture is commonly sugary. Streptelasmoid corals occur at the base, but otherwise identifiable fossils are rare.

The exposures near Eureka were probably originally very similar lithologically to the section at Lone Mountain, and the prevailing color of the exposur $\urcorner$ s on McCoy Ridge and on Hoosac Mountain is still a dark gray to black. However, intense brecciation and pervasive veining by silica have effectively destroyed any fossils or bedding that might make the correlation with the Lone Mountain section more certain.

The occurrence of a thin sand zone at the base $c^{f}$ the Hanson Creek has been mentioned. The upper contact of the formation, at least in the Roberts Mountains, Lone Mountain, and Antelope Valley, is a zone rich in bluish-black chert. We have not recognized this zone in New York Canyon at Eureka, although the estimated thickness there would suggest that somewhat more than the thickness of the Hanson Creek at Lone Mountain is present.

Merriam measured 560 feet of Hanson Creek be $1 s$ at the type locality, 318 feet at Lone Mountain, and 300 feet in Antelope Valley. We have made no measurements of thickness at any of the outcrops near Euneka, although on the east side of McCoy Ridge neas the mouth of New York Canyon, it is probable that at least 300 feet of beds are present.

\section{AGE AND CORRELATION}

In the type area, the Hanson Creek formation is quite fossiliferous, yielding Cryptolithus sp., various illaenid trilobites, Rafinesquina sp., and Columnaria? sp. At nearly all localities small Streptelasma-like corals are common. In the Monitor Range the most abundant fossils are graptolites, which have been assigned to the following species by Ruederann (Merriam and Anderson, 1942, p. 1686): Climacograptus tridentatus var. maximums, Orthograptus calcaratus var. trifidus, Orthograptus sp., and Dicellograptus complanatus var. ornatus. The fauna from Wood Cone reported by Hague (1892, p. 59) includes a "Trinucleus" (probably Cryptolithus sp.) and was at first regarded as Trenton in age. Good collections can be made in the Wood Cone area, but so far the faumas from that area have not been studied. Among the fossils present in some abundance are: Plaesiomys sp., bryozoans, small streptelasmid corals; tabulate corals, and cystid plates. 
The Hanson Creek formation correlates with dolomites found at numerous other places in the Great Basin, which are assigned locally to the Ely Springs or Fish Haven formations (Easton and others, 1953, fig. 2). Curiously enough, however, in view of its widespread distribution, equivalent beds were not reported by Sharp (1942) in the Ruby Range nor Spencer (1917, p. 24) at Ely; it is not improbable that more detailed future work at both places may show that they are actually present.

The faunas from all the localities indicate that the beds are of Richmond (Late Ordovician) age. Among the recently studied faunas is that from the Inyo Range, California, where the fossils are unusually well preserved by silicification and can be etched out from the matrix. This fauna is comparable to that of the Maquoketa shale in Iowa and therefore is of Richmond age. Among the common elements in it are species of the following genera: Heterorthis, Glyptorthis, Thaerodonta, Lepidocyclus, Platystrophia, Zygospira, and Plaesiomys. The corals include abundant Halysites, Columnaria, and streptelasmids. The occurrence of Halysites in these Richmond strata is not uncommon.

\section{WHSTERN FACIFS}

The fact that the lower Paleozoic rocks of western Nevada are in large part made up of clastic rocksshales and sandstones-in contrast with a dominantly carbonate sequence in the eastern part of the State, has been known since the days of the early surveys. Kirk (1933, p. 29) and Merriam and Anderson (1942, p. 1699-1701) have recently called attention to the existence of the two facies and have considered explanations for the relationships between them.

Hague did not recognize the presence of any sediments of what is now generally referred to as the western facies in the course of the Eureka survey, and his discussion of a nearby Paleozoic shoreline (1892, p. 175185 ) is based on other and quite different types of evidence, although he may well have been influenced in this discussion by a knowledge of the differences between the Eureka and Silver Peak Cambrian sections (1892, p. 189).

Recent work has shown that Ordovician sedimentary rocks belonging to the western facies extend into the Eureka area as a result of major thrust faulting; comparable Cambrian rocks have not been found in the overriding thrust block. The Ordovician rocks have been assigned to the Vinini formation.

\section{VININI FORMATION}

The Vinini formation was named and described by Merriam and Anderson (1942, p. 1693-1698) from exposures on Vinini Creek on the eastern slope of Roberts Creek Mountain, 25 miles airline northwest of Eureka.
The formation is extensively exposed in the Roberts Mountains and along the western and southern flanks of the Sulphur Spring Range to the east. From Mount Hope, about at the junction of the two ranges, exposures of the Vinini are essentially continuous southwards along the west side of Whistler Mountain to Devils Gate. South of Devils Gate there are additional outcrops of the formation east of Yahoo Canyon that extend to within 4 or 5 miles wert of Eureka. These exposures were mapped by Hague as belonging to the Diamond Peak quartzite of Cark nniferous age (1892, p. 141-142, 145-146). Graptolites characteristic of the Vinini, however, have been collected from these exposures. Additional exposures of the Vinini are found along the western and nortlern flanks of Lone Mountain and at the northern end of the Monitor Range on the west side of Antelope Valley.

Merriam and Anderson recognized at least two and possibly three divisions of the Vinini. Of them they wrote (1942, p. 1694-1698):

Lower Vinini.--Lower strata of the Vinini formation are best exposed on the east side of Roberts Creek Mountain, along the main east fork of Vinini Creek. T'e deposits here consist of dark-gray, brownish-weathering betded quartzites, gray arenaceous limestones or calcareous sandstones commonly showing crosslamination, and fine laminated sandy and brownishgray and greenish-brown silty sediments. Locally the silty beds have a shaly parting, and in some localities true black shales are present in the lower Vinini.

Near the top of the lower Vinini, lava flows and tuffs occur at several localities. These are particularly well shown about 3 miles south of Roberts Creek Mountain just east of Roberts Creek. Here 40 feet of tuff-breccia grades upvrard into several feet of greenish volcanic sand overlain by cherty shale, typical of the upper Vinini. Nearby an amygdaloidal lava flow about 40 feet thick is exposed, also overlain by cherty shale of the upper Vinini. At two other localities, only arygdaloidal lava was observed, such as the outerop previously noted along Vinini Creek and on the west flank of Roberts Creek Mountain 4 miles east of the mouth of Jackass Creek ... The tuffs and lavas presumably were hornblende anderites that have been chloritized, and, with the exception of the lava flow containing andesine phenocrysts, extensive albitization has taken place.

*

Among the abundant graptolites of the lower Vinini on Vinini Creek, Ruedemann has recognized the following forms:

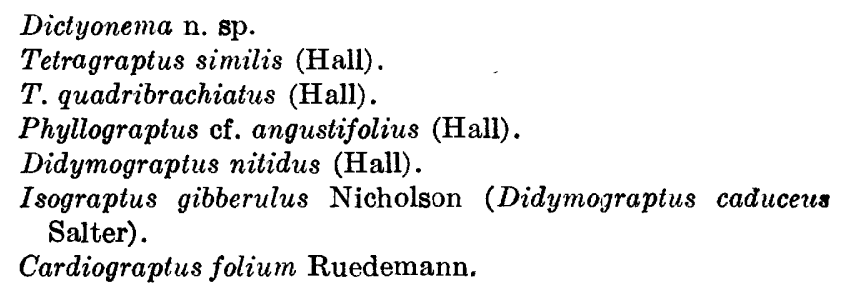

In addition small orthoid brachiopods and the trilobite Pliomerops occur in sandy or quartzitic layers immediately above 
the graptolite faunule listed. Hexactinellid sponge spicules are very abundant in certain graptolite beds.

Ruedemann regards the graptolite assemblage as clearly of the same age as the Tetragraptus beds of the lower Deepkill shale in New York State, or of lower Canadian (Beekmantown) age. The fauna is also well represented in the Ordovician of Idaho and British Columbia. Of particular interest is the Australian genus Cardiograptus found also in the Idaho and British Columbia faunules.

Several additional graptolite localities have been found in the lower Vinini on both the east and west side of the Roberts Mountains as well as the central part of the range. In some places the graptolites occur in quartzitic beds as well as in the silty and shaly deposits. Judging from diversity of the graptolite faunules at these localities, probably several graptolite horizons are represented within the lower Vinini.

Upper Vinini.-A succession of bedded cherts and black organic shales constitutes the upper Vinini which follows the lavas and tuffs of the lower division. In most sections studied the chert beds and lenses make up more of the thickness than the shale interbeds, though at certain exposures only the shale was recognized. Except where the resistant cherts are exposed, outcrops of this unit are often poor ... The chert layers generally vary in thickness from 1 to 4 inches ... while the organic shale partings are frequently less than 1 inch thick. In spite of the black color of the organic shale and the black to dark-gray and greenish color of much of the chert when fresh, both shale and chert tend to weather limonite brown, cream, white, and grayish white. From a distance, whitish outcrops of upper Vinini may be mistaken for tuff. Along Vinini Creek and at other localities throughout the Robert Mountains region the shales are readily ignited. The oil yield on distillation of selected samples is above 25 gallons per ton. Where the black shale interbeds have a high content of bituminous matter, the dark chert layers probably carry much of the same.

Within the shale interbeds rounded or walnut-shaped nodules are common. These sometimes consist of a combination of siliceous and bituminous material with some calcium carbonate and of ten much pyrite. The nodules resemble small coal balls and on sectioning reveal well-preserved organic remains (Merriam and Daugherty, 1938). The shales and particularly the nodules are highly graptolitic, also bearing large quantities of Radiolaria, and microscopic algae. The highly bituminous or oil-bearing shale facies is apparently limited to the central and eastern Roberts Mountains belt, extending from the Vinini Creek drainage southward to Devils Gate.

... The siliceous strata are clearly not the result of silicification of earlier sediments but are original primary bedded cherts, separated by thin shale partings. The chalcedonic cherts are pale green to black, with layers ranging from 1 to 4 inches in thickness, a few reaching 1 foot or more. On a fresh moistened fracture surface, clear round areas can be detected with a hand lens, resembling outlines of Radiolaria such as characterize cherts of the Jurassic Franciscan formation in the Coast Ranges of California. Under the microscope, these areas appear as clear minute aggregates of quartz or chalcedony, the latter arranged in spherulitic fibers, similar to the Radiolaria as described by Davis $(1918$, p. 257$)$ in the Franciscan cherts. In some, the chalcedonic fibers are surrounded by microgranular quartz. The clear areas are surrounded by cryptocrystalline silica which polarizes feebly. In the gray to black cherts, dark-brown isotropic spots are visible in thin section. These resemble organic matter (bituminous ?) such as that which characterizes some Miocene cherts of the Coast Range in California (Davis, 1918, p. 288). Quartz veinlets are common in the cherts repres?nting minute fracture lines later sealed with quartz.

* * * * * * *

. . From black organic shales of this division the following graptolite species have been identified by Ruedemann:

Leptograptus flaccidus (Hall) var. spinifer Elles and Wood mut. trentonensis Ruedemann.

Dicranograptus spinifer Lapworth.

Diplograptus angustifolius (Hall).

Orthograptus calcaratus var. acutus Lapworth.

Climacograptus bicornis (Hall), narrow variety.

C. modestus Ruedemann.

Retiograptus geinitsianus (Hall).

In addition to graptolites, the upper Vinini beds contain abundant Radiolaria, thin-shelled protremate brachiopods, ard microscopic protophycean algae (Merriam and Daugherty, 1938). Ruedemann has concluded that this faunule is of upper Normanskill age and identical with faunules from Bruno Creek, Bay Horse quadrangle, Idaho, Fall Creek, Hailey quadrangle, Idaho, and British Columbia. Typical Dicranograptus spinifer as found in the Vinini shale has not been observed in eastern North America but occurs in the Idaho localities here mentioned.

Garden Pass (Summit) graptolite zone.-An important graptolite faunule was collected at Garden Pass (Summit), Nevada, by Walcott (Gurley, 1896, p. 302). This assemblage, one of the first found in western America, occurs on the old right of way of the defunct Eureka and Nevada railroad where it traverses the low pass separating the Roberts Mountains block fro' $a$ the Sulphur Spring Mountains. The exact association has not, been recognized elsewhere in the Vinini formation and probabl: represents a zone between that of the lower Vinini and the upper Vinini organic shales and cherts. On a paleontologic basis it is therefore likely that at least a three-fold subdivision of the Vinini formation is possible with a time range from lower Canad:an to upper Chazyan. The long interval of Ordovician time involved emphasizes the possible thickness of these highly dislocated and eroded overthrust rocks.

Graptolites collected by Walcott (Gurley, 1896, p. 302) "at the crossing of the Eureka and Palisade Railroad at Summit, Nevada," have been identified by Lapworth, Gurley, and F.uedemann. The forms listed by Gurley are as follows:

Dendrograptus cf. serpens Hopkinson.

Didymograptus perflexus Gurley.

Phyllopgraptus sp. indet.

Diplograptus sp.

Climacograptus caelatus.

Cryptograptus tricornis.

Glossograptus ciliatus.

Thamnograptus anna.

Ruedemann regards the form referred to Glossograptus ciliatus by Lapworth (manuscript report) and by Gurley (1896) as a "mutation" of this species which he described as Glossograptus ciliatus mutation horridus. According to Ruedemann (1908, p. 384) the following forms are associated at the Garden Pass (Summit) locality:

Glossograptus ciliatus mutation horridus.

Phyllograptus anna.

Climacograptus caelatus.

Cryptograptus tricornis.

Caryocaris.

On the basis of this assemblage the deposits at Garden Pass (Summit) have been regarded by Ruedemann as probably Upper Beekmantown. 
Whether the graptolite specimens collected by Walcott and identified by Lapworth and Gurley were all obtained from exactly the same zone is not known. The possibility that they represent more than one zone must be considered in view of structural complexity in these shaly deposits at Garden Pass (Summit). The graptolitic deposits in this region are known to include several clearly defined divisions. As listed the Garden Pass (Summit) faunule is distinct from those recognized on Vinini Creek and at other localities throughout the mountain area, appearing on paleontologic grounds to require a stratigraphic position between the lower Vinini and upper Vinini assemblages.

Because of profound dislocation of the Vinini formation it has not been possible to obtain reliable figures for thickness of the two divisions. However, on Vinini Creek the combined thickness remaining probably cannot be less than 500 feet, and much of this section has certainly been removed by erosion. Black graptolitic shales and cherts at the north end of the Simpson Park Range west of McClusky Pass appear to represent only the upper Vinini and may greatly exceed the figure given for this division alone.

We have done a little additional detailed mapping of the Vinini south and southeast of the Mount Hope mine chiefly in beds assigned to the upper part of the Vinini. Here there are rare thin limestones interbedded with the dominant organic shales and cherts. Careful mapping of distinctive rock sequences shows that the Vinini rocks have been folded and cut by local minor thrust faults, and that both folds and thrust faults seem clearly to be transgressed by an unconformity at the base of the overlying Permian sequence. Here, therefore, no Silurian, Devonian, or Carboniferous rocks are present in the thrust plate that brought the Vinini and associated Permian rocks eastward.

In terms of the eastern facies at Eureka, the Vinini formation is in general equivalent to the Nimemile formation and Antelope Valley limestone.

\section{SILURIAN SYSTEM}

Rocks of probable Silurian age are rather widely distributed in the area around Eureka. In the region east of the town, however, where most of our detailed mapping has been concentrated, there appear to be no continuous sections; and the beds in the partial sections assigned to the system are not only essentially unfossiliferous, but are in most places deformed and altered to such an extent that satisfactory stratigraphic study of them has not been possible.

Complete sections are, however, present west of Eureka in the as yet inadequately mapped areas of Roberts Mountains, Lone Mountain, Spring Valley, and Antelope Valley. These provide a basis for interpreting the more easterly sections, but it is not unlikely that extension of detailed mapping westward into these areas may require modification of some current concepts of the Silurian sequence.

Hague (1883, p. 262-263; 1892, p. 57-60) established the Lone Mountain limestone of the Eureka district to include not only all sedimentary rocks in what is now the Silurian system, but also the beds which have been described above as the Hanson Creek formation, of Late Ordovician age. Hague and Walcott $(1884$, p. 4, 284) recognized that there were two faunas of quite different ages represented in Hague's Lone Mountain limestone, but Kirk (1933, p. 30) appears to have been the first to suggest that Hague's Lone Mountain should be restricted by the exclusion of the Ordovician sediments. Most subsequent authors seem to have accepted this emendation and assign only a Silurian ag? to the Lone Mountain. Merriam (1940, p. 13-14) further redefined the Lone Mountain at the tyFe locality to exclude some darker colored beds at the base which are dominantly limestone and which contrast in color and composition with the lighter colored dolomites above. The lower unit was named the Roberts Mountains formation by him; he also proposed that the upper, unfossiliferous, beds be assigned to a still further restricted Lone Mountain formation.

This usage is accepted for the present report, and the tormations of Silurian and probable Silurian age are considered to consist of a lower Roberts Mountains formation and an upper Lone Mountain dolomite. The substitution of "dolomite" for "limestone" (Hague usage) or "formation" (Merriam 1940 usage) appears desirable, in view of the dominantly dc'omitic character of the beds now assigned to the Lone Mountain.

Whereas the restricted Lone Mountain dolomite in the mapped area east of Eureka is unfossiliferous, evidence of Late Silurian age of a zone in the higher part of the dolomite unit has recently been obtained from a locality north of Wood Cone, 12 miles southwest of Eureka (Merriam, 1956). Somewhat ruzzling is the occurrence of Lower Devonian (Helderbergian) fossils in limestones overlying the Roberts Mountains formation on the west side of Antelope Valley. Prior to discovery of the Helderbergian fossils these limestones appeared to occupy the interval of the Lone Mountain dolomite to the east. It is possible that these problematic relations may be explainable on the basis of unconformities. Discovery of a Lower Devonian (Oriskany) fauna near the top of similar dolomites to the south (McAllister, 1952, p. 15-16) suggests the possibility that accumulation of carbonate rocks similar to those of the Lone Mountain dolomite persisted locally at least beyond the close of Silurian time.

\section{ROBERTS MOUNTAINS FORMATION}

GENERAL FEATURES

The Roberts Mountains formation, as defined by Merriam (1940, pp. 11-12), is found only in the region west of Eureka. The type locality is the west side of Roberts Creek Mountain, about 30 miles northwest of 
Eureka. Beds correlated with this formation have been found at Lone Mountain, the Monitor Range, and other localities west of Eureka (Merriam, 1940, p. 12; Merriam and Anderson, 1942, p. 1687-1688). Northwest of Wood Cone, 12 miles southwest of Eureka, there are beds assigned to the Roberts Mountains formation; they have not been recognized in the exposures of supposed Silurian rocks immediately south of Eureka or in the region to the east.

The Roberts Mountains formation eonsists largely, although not encirely, of limestone that contains abundant Silurian fossils. At the type section the base of the formation is drawn at the bottom of a massive bed of black chert below which lies the Hanson Creek formation. What appears to be the same basal chert is also found on the west side of Antelope Valley and at Lone Mountain, where it is 85 to 100 feet thick. This chert member may be very widespread in the Great Basin, as a similar siliceous bed is found in approximately the same stratigraphic position as far away as the Inyo Mountains in California.

On the west flank of Roberts Creek Mountain the formation may be divided into a lower part, about 1,100 feet thick, composed of medium-gray to medium-darkand dark-slate-gray flaggy platy and shaly limestone, and an upper part, roughly 800 feet thick, in which the beds tend to become more massive and somewhat dolomitic. These beds are overlain by 250 feet of light-gray dolomite that marks the base of the Lone Mountain dolomite. The platy to shaly limestone in the lower part is in part silty and medium to finely crystalline in texture; coarser grained crinoidal members as much as 2 feet thick are intercalated. Many of the beds throughout the formation are highly organic, yielding well-preserved fossils, particularly corals and brachiopods. Chert is not wholly confined to the basal zone, but persists upwards for a few hundred feet as sporadic lenses.

At Lone Mountain, the lithologic character is quite different. Above the basal black chert zone, the beds are largely dolomitic, and the upper boundary with the restricted Lone Mountain dolomite is a zone within which the darker gray dolomites of the Roberts Mountains formation change to the lighter grays of the higher formation. In the Monitor Range, on the west side of Antelope Valley, on the other hand, the formation is again limestone containing Monograptus in great abundance. Although there is evidence in some of these localities that there has been hydrothermal dolomitization, the relationships in general indicate that most of the limestone and dolomite is of sedimentary origin.

Thickness figures for the Roberts Mountains formation seem to have only local value. The unit does not appear to be present near Eureka, but is 1,970 feet thick at the type locality in Roberts Creek Mountain. The thickness of beds that might be assigned to the formation at Wood Cone is probably less than 100 feet, but the unit thickens toward the southwest and north; Merriam has measured 741 feet of dolomitic limestone at Lone Mountain and about 650 feet of limestone on the west side of Antelope Valley. Figures for the combined thickness of the Lome Mountain dolomite and the Roberts Mountains formation would probably have greater significance, but these are not available as yet in many places.

\section{AGE AND CORRELATION}

The Silurian (Niagara) age of the Roberts Mountains formation is established by a fairly large fauna of brachiopods, corals, and graptolites. Halysites sp., Heliolites sp., and favositids are abundant in the lower and middle portions of the formation, together with Conchidium sp., and other brachiopods. In the upper 700 feet, there are several coral-bearing horizons, some with prolific favositid assemblages; others with heads of the Strombodes type (Merriam, 1940, p. 12; Merriam and Anderson, 1942, p. 1687). Brachiopods of the genera Dicoelosia and Homoeospira from these upper beds further support a Silurian assignment.

Aside from the occurrences cited above, the Poberts Mountains formation has not been reported. W'ork in progress west and north of Eureka (James Gilluly, oral communication) suggests that it may be more widely present in those directions than is sugges ed by the literature. Eastward the formation is probably equivalent to some, or even all, of the beds assigned to the Laketown dolomite which is widespread in Utah. In the Inyo Mountains in California the Silurian dolomites are locally replaced by a highly fossiliferous limestone facies; the fossil evidence indicates that these limestones are equivalent in part to the Foberts Mountains formation.

\section{LONE MOUNTAIN DOLOMITE}

GENERAL FEATURES

The Lone Mountain dolomite was named by Hague (1883, p. $262-263 ; 1892$, p. $57-60)$, from the section exposed on Lone Mountain. As thus defined, the formation included all the strata between the Jureka quartzite and the Nevada limestone, although Hague noted that the contact with the latter was rather indefinite. Kirk $(1933$, p. 30) was the first to report that the lower part, now separated as the Hanson Creek formation, was lithologically distinct, but the formation was not formally redefined until 1940 when Merriam (1940, p. 10, 13-14), restricted the unit by the elimination of both the Hanson Creek formation and the Roberts Mountains formation. 
The Lone Mountain dolomite is rather widely distributed in the vicinity of Eureka, but many of the sections of the formation are either incompletely exposed or are so deformed that their stratigraphic position or significance is somewhat uncertain. The best sections are probably those at the type locality of Lone Mountain and at Roberts Creek Mountain, where the relationships to the Roberts Mountains formation can be seen. Less satisfactory exposures are found on the west flank of the Diamond Mountains, west of north from Diamond Peak; at the south end of this range, east and south of Pinto Summit; the southern part of the Sulphur Spring Range; the north end of the Fish Creek Range; in the hills west of Spring Valley, extending north to Devils Gate; and on the east side of Antelope Valley. The exposures of the Hanson Creek formation just south of Eureka may include some beds at the base of the Lone Mountain, but the rocks here are so thoroughly deformed that we have mapped all of them as Hanson Creek.

The Lone Mountain dolomite is characteristically a heavy-bedded to massive blocky-weathering saccharroidal dolomite of medium- to light-gray color on the weathered surface. As a rule the formation produces prominent and rugged exposures, which, as Hague (1892, p. 58) observes, present "a monotonous appearance wearisome to the eye." On fresh fracture the dolomite varies from finely granular to coarsely saccharoidal. Although the color is predominantly light to very light gray there are medium- to dark-gray phases. Chert is usually absent and the dolomites appear relatively pure. As a result of recrystallization organic remains which may have been present have been obliterated, as have also in many places unequivocal indications of bedding. However, near the base at a few points beds of coarse crinoidal dolomite have been found, and at Lone Mountain a poorly preserved Syringopora occurs in the lower few feet. Hague $(1892$, p. 61) reported the occurrence of Halysites sp. in the basal beds of the Lone Mountain dolomite as herein defined, but we have not been able to confirm this. North of Wood Cone an Upper Silurian fauna with spiriferoids of the Howellella type has recently been discovered in the upper 600 feet of the dolomite.

Merriam and Anderson (1942, p. 1688) describe the lower contact of the formation at Lone Mountain and Roberts Creek Mountain as gradational and as a zone in which the darker limestones and dolomites of the Roberts Mountains formation give way to the lighter colored saccharoidal dolomite of the Lone Mountain dolomite.

The upper contact has likewise been described as gradational (Hague, 1892, p. 58; Merriam, 1940, p. 14; Merriam and Anderson, 1942, p. 1688). In two areas in which we have done detailed mapping, however, we have recognized a persistent and well-defined plane of demarcation between typical saccharoidal dolomite of the Lone Mountain and lithologically distinctive dolomites that we regard as basal to the $I^{\top}$ evada formation. One of these is in Oxyoke Canyon south and east of Pinto Summit. Here a sharp and somewhat irregular contact, probably an unconformity, may be traced between sugary light-gray dolomites of the Lone Mountain below and very dense white-weathering dolomites of Devonian age above. The contrast between the two texturally distinct dolomites is heightened by a distinct color difference, the dolomites of the Lone Mountain being yellowish, those of the Devonian faintly bluish. There appears to be several feet of relief along the contact, and the uppermost Lone Mountain strata commonly are sedimentary breccias with fragments several inches across. The basal Devonian in contrast is not conglomeratic, but may be composed in places of as much as 6 inches of dolomite sand.

The other locality is on the west flark of the Diamond Mountains in the belt of middle Paleozoic rocks near the Phillipsburg Mine. The dense light-gray dolomite of earliest Devonian age here has 50 to 75 feet of sandstone or quartzite at its base, and the contact between this and dolomites assigned to the Lone Mountain dolomite below is as sharp as in the regior farther south. A sedimentary breccia, similar to the one to the south, is present locally at the top of the Lone Mountain strata.

Similar sedimentary breccias have been recognized at this approximate horizon at two places west of Spring Valley, west of Eureka, and at one place in the Sulphur Spring Range, but in the absence of detailed mapping in these localities it is hazardous to correlate them definitely with the breccias at the top of the Lone Mountain dolomite in the Diamond Mountains. They suggest, however, that the apparent unconformity in the Diamond Mountains may extend over a wider region and may in fact be an ertension of the unconformity beneath the Devonian that has been reported in the Nopah and Resting Springs Ranges to the south (Hazzard, 1937, p. 327) and at Gold Hill to the east (Nolan, 1935, p. 18).

The Lone Mountain dolomite in the Eureka area ranges in thickness from 1,500 to 2,200 feet. Only two complete sections have been measurad: one at the type locality being 1,570 feet thick ( $\mathbf{M}^{\text {Terriam, }}$ 1940, p. 13), and another at Roberts Creek Mountain, 2,200 feet thick (Merriam and Anderson, 1942, p. 1688). These figures are comparable to the 1,80 ? to 2,000 feet estimated by Hague (1892; p. 58-59), and to several partial sections in the Diamond Mountains. Just south 
of the Phillipsburg Mine, for example, there appears to be at least 2,000 feet of Lone Mountain dolomite along the west base of the Mountains, in the footwall of a fault that drops limestones of the Carbon Ridge formation into contact with the dolomite. There is about a thousand feet of dolomites of the Lone Mountain exposed in the incomplete sectious in Oxyoke Canyon southeast of Eureka.

\section{AGE AND CORRELATION}

The direct paleontologic evidence for age of the Lone Mountain dolomite (restricted) in the Eureka region is scanty. Until very resently, in fact, there was no fossil evidence in the type area which served to establish a Silurian age with certainty. Further confusion arose with recognition of Lower Devonian (Helderberg) faunas in limestones in the western Antelope Valley area which seemingly occupy some part of the Lone Mountain stratigraphic interval.

Merriam (1940, p. 13) collected a poorly preserved ?Syringopora from within a few feet of the base of the formation at Lone Mountain, s.bout at the horizon where Hague earlier reported the occurrence of Halysites sp. Aside from some crinoid columnals in the lower portion of the formation on Roberts Creek Mountain, these constitued the only fossils found in the formation until the summer of 1954 , when a collection of corals and brachioporls was made from a black dolomite about a mile and a half north of Wood Cone, southwest of Eureka. The area in which the collection was made has not as ret been mapped, but the fauna probably lies within 1, he upper 600 feet of the Lone Mountain dolomite. It contains spiriferoids of the Howellella type and probably is Upper Silurian. The possibility that the highest Lone Mountain strata, above the Hovellella zone, may be as late as Helderbergian has not been eliminated.

Additional collecting and mapping in this region may help to clarify the existing apparent contradictions presented by faunas from dolcmites similar to the Lone Mountain to the east and west. McAllister (1952, p. 14-17), for example, has reported a Lower Devonian fauna in the uppermost beds of the Hidden Valley dolomite of the Quartz Spring area in California, and regards the Hidden Valley as correlative in part with the Lone Mountair. The western-facies limestones at Antelope Valley carrying a Helderberg fauna overlie beds correlated by Merriam (1956) with the Roberts Mountains formation, which normally underlies the Lone Mountain dolomite (restricted). The possibility that the Lone Mountain dolomite as a whole and the limestone of Helderberg age in question are correlative seems unlikely in view of the Upper Silurian Howellella fauna recognized in the upper 600 feet of the Lone Mountain north of Wood Cors. It is nevertheless conceivable either that the righest strata of the Lone Mountain dolomite above Hovellella may be Helderberg in age or that pre-Helderbergian and pre-Oriskany erosion may be responsib'e for the relationships observed.

On the other hand, thick dolomites occupying the same stratigraphic position as the Lone Mountain do ${ }^{1}$ mite are fairly widespread in western and northern Utah, where they have been generally assigned to the Laketown dolomite (Richardson, 1913, p. 410). In the more northerly localities the thicknesses range between 1,000 and 2,000 feet, and the dolomite in some places contains a fairly extensive coral and brachiopod fauna which appears to be the same as that of the Silurian Roberts Mountains formation. The distribution of these thicker sections has been summarized by F. F. Hintze (1949, p. 55-57) and Nolan (1943, p. 151-152). Devonian sedimentary rocks overlie the Laketown dolomite; and in western Utah at least the basal Devonian tormation appears to be lithologically like, and correlative with, the basal member of the Nevada formation at Eureka. These dolomites in Utah, therefore, suggest that the Lone Mountain is correlative with the Laketown and is of Silurian age.

Dolomites have been reported from some of the intervening areas between Eureka and the Utah localities, but like the exposures at Eureka they are poorly fossiliferous. Sharp (1942, p. 660-661), for exemple, reports 1,350 feet of dolomite in the Ruby Pange, which he assigns to the Lone Mountain dolomite, and Spencer $(1917$, p. 25) suggested that there might be representatives of the dolomite in the thick section of Nevada limestone at Ely. Farther south and southeast dolomite at this horizon appears to be either much thinner, or is entirely absent (Hazzard, 1937, p. 36; McAllister, 1952, p. 17-18).

The Lone Mountain dolomite at Eureka, so far as the available evidence goes, may thus be either of Silurian or Early Devonian age, or include beds of both ages; and it may be either younger than a Roberts Mountains formation which lenses out eastward beneath it or be the eastern dolomitic equivalent of a western limestone-rich Roberts Mountains formation. A satisfactory choice between these alternatives will probably depend upon the results of detailed mepping between Eureka and the Monitor Range. This should show the extent, if any, of interfingering between the limestones characteristic of the Roberts Mountains and typical Lone Mountain dolomite and also the stratigraphic position of the beds containing a Helderberg fauna relative to the supposed unconformity that has been mapped east of Eureka between the Lone Mountain dolomite and the Nevada formation. 
The recently discovered fauna in supposed Lone Mountain strata north of Wood Cone supports an assignment to the Silurian of at least part of the Lone Mountain dolomite at Eureka. It suggests, moreover, that the limestone-dolomite relationships of the Roberts Mountains and Lone Mountain formations are comparable to similar westward changes of dolomite to limestone that are found in the Upper Ordovician and in parts of the Devonian section.

\section{DEVONIAN SYSTEM}

Rocks of Devonian age are widely distributed in the region around Eureka; they underlie a larger area than those of any other Paleozoic system. ${ }^{10}$ The stratigraphic section which they provide, in addition to its extensive areal extent, is also both above average in thickness and exceptionally inclusive of the several subdivisions of the system in the Great Basin region. The nature of the exposures was recognized by Hague (1892, p. 63) who predicted that it would "long remain a typical one for the study of Devonian strata."

Hague distinguished and described two formations in the Eureka district as composing the 8,000 feet of beds that he assigned to the Devonian (1883, p. 264-267; 1892, p. 63-84). These were the Nevada limestone below and the White Pine shale above. Merriam, as a part of a study of the Devonian of the Roberts Mountains region, which adjoins and in part overlaps the Eureka district on the northwest, materially modified Hague's Devonian section (1940, pp. 10-17). He eliminated the White Pine shale (Merriam, 1940 , p. 8 , p. 45-46), which he assigned to the lower Carboniferous, and restricted Hague's term Nevada limestone to a redefined Nevada formation of Early and Middle Devonian age. The upper part of the old Nevada limestone was assigned to a new formation, the Devils Gate limestone, of Middle and Late Devonian age.

We have accepted Merriam's two units, the Nevada formation (restricted) and Devils Gate limestone, and have further recognized and mapped over much of the region east of Eureka, five lithologically distinct members of the Nevada formation and two members of the Devils Gate limestone. In addition we have distinguished, and mapped separately, the basal beds of Hague's White Pine shale. This, following Spencer $(1917$, p. 26), has been called the Pilot shale; at Eureka it contains a conodont fauna of Late Devonian age.

Hague's thickness of 8,000 feet for the Devonian appears to be excessive, in the light of our work, which would suggest a total thickness of from 3,000 to 5,000 feet. Hague's figure is in part due to the inclusion of beds in his White Pine shale which are now assigned to the Mississippian and in part to unrecognized faults which caused duplication of strata in some of the sections that he believed provided unbrol-en sequences.

\section{NEVADA FORMATION}

The first use of the term Nevada in a stratigraphic sense was by Clarence King (1878 Atlas, map 4) for Devonian rocks in the eastern Great Brsin. Hague, however, comes closer to providing an original definition of the unit, as a result of the mapping in the Eureka district. In his first publication on Eureka (1883, p. 264) he in effect selected the entire State as the type locality, as he notes that "the name selected to designate this horizon is taken from the name of the State . . .." Later $(1892, p .65)$, this broad designation was modified by the citation of Modoc Peak, Combs Peak, Atrypa Peak, Woodpeckers Peak, and Newark Mountain, all within the area of the original Eureka survey, as affording "typical sections."

Hague's failure to designate a single localicy as the type was perhaps the result of his ccnclusion that although the formation as a whole is uniform in its lithologic characteristics, "the details across any one section are not persistent enough to determine with precision the horizons over any extended area." Although we have also recognized lateral changes in the formation, the recent work would suggest that at least part of Hague's failure to recognize and trace subdivisions was due to widespread faulting over most of the exposures of Devonian rocks, together with local lowgrade metamorphism resulting from small intrusive dikes and plugs.

Merriam (1940, p. 15) in redefining $\varepsilon$ nd resiricting the Nevada formation selected Modoc Peak, the first of the five localities cited by Hague, as \&. suitable type locality. Such observations as we have made of this section in advance of detailed mapping, indicate that there is probably a complete section of the Nevada formation exposed there. The section is cut, however, by several minor faults and by at least two intrusive masses. In view of the apparent priority given by Hague, and of Merriam's subsequent designation, it is probably best to retain Modoc Peak as the type locality, although it would be well to supplement any observations made on this section by others in the perhaps more representative sections in Oxyoke Canyon on the east, and Lone Mountain to the northwert.

The Nevada formation is probably the most widely distributed of the Paleozoic formations in the Eureka

\footnotetext{
10 In a paper published after this report was written, J. C. Osmond (1954, Dolomites in Silurian and Devonian of east-central Nevada: Bu'. AAPG, v. 38, pp. 1911-56) has reached some conelusions concerning sections of d)lomitic rocks in eastcentral Nevada that differ in some respects from those express ad in this paper. He extends the names "Sevy" and "Simonson" dolomite from western Utah into central Nevada and correlates the Sevy with our Lone Mountain dolomite and assigns it to the Silurian and Early Devonian; the Simonson is correlated with the Nerada formation and is considered to be of Early and Middle Devonian age.
} 
area. It is well exposed in the Diamond Mountains: along the west flank from Black Point to north of the Phillipsburg Mine; on Newark Mountain, southeast of Diamond Peak; and in the hills southeast of Eureka from Woodpeckers Peak to Silverado Mountain and the Alhambra Hills. Much of our recent work has been concentrated on these three series of exposures. West of Eureka there are extensive outcrops of the formation in the Sulphur Spring Range; Roberts Creek Mountain; Lone Mountain; the Mahogany Hills, lying west and north of Spring Valley; and in the Fish Creek Range, east and south of the valley.

Lithologically, the formation is composed dominantly of dolomite. Appreciable thicknesses of limestone and sandstone occur, however, in places to the extent that they may be separately mapped. The occurrence of limestone and sandstone is also significant in that their distribution with respect to the dolomite suggests a iacies change in the formation from east to west.

In the eastern exposures, where most of our mapping has been concentrated, a thick unit of sandstone and one predominantly of limestone separate three units of dolomite. These five units appear to be sufficiently extensive and distinctive to warrant their separation as members of the Nevada formation; we have named them, in ascending order: the Beacon Peak dolomite member, the Oxyoke Canyon sandstone member, the Sentinel Mountain dolomite member, the Woodpecker limestone member, and the Bay State dolomite member. These units appear to be valid for a north-south distance of much more than 25 miles in the Diamond Mountains; and in such work as we have done west of Eureka it would seen that they are valid at least in part there as well.

The western exposures, however, provide some evidence that in the Nevada formation, as in the Hanson Creek formation and the Lone Mountain dolomite, limestone tends to replace dolomite westward. Both the Beacon Peak dolomite member and the Oxyoke Canyon sandstone member-which has not only interbedded dolomite beds but a dolomitic cement in the sandstones-appear to be represented in the Mahogany Hills, the Sulphur Spring Range, and other western areas by fossiliferous limestones with only remnants of the eastern dolomite-rich lithologic type. The three upper members seem to be less subject to this facies distinction. It is possible that the wesiward replacement of dolomite by limestone in these middle Paleozoic formations indicates an approach to an ancient shoreline; much additional work needs to be done, however, to establish the validity of this speculation.

Previous descriptions of the Nevada formation have indicated that its boundaries with the Lone Mountain dolomite below and the Devils Gate limestone above are gradational. Hague, for example, writes (1892, pp. 63-64) "the transition in sedimentation from characteristic Silurian to unmistakable Devoniar is so imperceptible that a boundary between them is impossible to establish ...." a conclusion that Merriam (1940, p. 14) accepted on the basis of his work at Lone Mountain and at Roberts Creek Mountain. Similarly, Merriam reported an arbitrary boundary based on a fauad change between the Nevada tormatior and the Devils Gate limestone.

Recent work suggests that these conclusions need some modification. As noted in the section on the Lone Mountain dolomite, the contact between the Lone Mountain and the Nevada formation throughout the Diamond Mountains is sharp and is a plane of discontinuity that may represent an unconforrnity. The sharp lithologic change, the irregularities $\varepsilon . t$ the contact, the presence of sedimentary breccias below the contact, and the local occurrence of a sanc'stone above it, are all indicative of a break in sedimentation. At a few widely separated localities west of Eureka in the Mahogany Hills there appears to be a sedimentary breccia similar to that in the Diamond Mountains at a stratigraphic position that may represent the base of the Nevada, but detailed mapping has not been done as yet to establish jts significance. One such lonality was found south of Table Mountain on the west side of the Mahogany Hills. At this place there is a mudbreccia or edgewise limestone conglomerate at the top of beds thought to belong to the Lone Mountain dolomite; an erosion surface separates the conglomerate from the overlying sedimentary rocks. The gray dolomitic limestones which are above the contact contain large streptalasmoid corals like those found not uncommonly near the base of the Nevada formation; still higher, typical lower Nevada brachiopods were found.

Whether or not detailed work will show that an unconformity exists at this horizon is uncertain; it seems likely that at least some of the localities where gradational relations have been thought to exist subsequent hydrothermal dolomitization or recrystrllization has so destroyed the original relationships that the presence or absence of unconformity may be imporsible to establish.

No similar sharp contact at the upper boundary of the Nevada formation has as yet been found. The faunal break, which was used by Merriam as indicative of the contact, however, has been supplemented by the recognition of a lithologic change from limestone to dolomite. This occurs within a relatively narrow zone of some 50 feet in thickness. 
The Nevada formation has a fairly constant thickness over the whole region around Eureka. Merriam reported 2,448 feet on Lone Mountain (1940, p. 14) and about 2,400 feet on Roberts Creek Mountain (1940, p. 34). We measured about 2,550 feet in Oxyoke Canyon in three partial sections. Northwards on the west flank of the Diamond Mountains the thickness appears to increase, as we measured a total thickness of about 2,650 feet just north of Black Point and about 2,900 feet in the latitude of the Phillipsburg mine.

\section{BEACON PEAK DOLOMITE MEMBER}

The basal member of the Nevada formation is well exposed in Oxyoke Canyon; the exposures on the lower west slope of Beacon Peak in the Canyon provide the type locality for the unit. It is also found in several fault blocks south and east of Oxyoke Canyon as far as the small drainage channel that separates the Alhambra Hills from Silverado Mountain. An equally extensive belt of exposures of the member is on the west flank of the Diamond Mountains from Black Point to north of the Phillipsburg Mine. West of the longitude of Eureka the evidence available suggests that the dolomite typical of the member is to a considerable extent replaced by fossiliferous limestones, although some beds characteristic of the Beacon Peak may still be recognized.

Lithologically, the Beacon Peak dolomite member is notably uniform throughout its entire thickness in the exposures east of Eureka. It is composed almost completely of beds of dolomite that on fresh fracture are a rather uniform light olive gray to slightly brownish creamy gray in color, but which weather to a pale gray to white that has a faint blue tinge. This contrasts with the yellowish tint shown by the underlying Lone Mountain dolomite. The dolomite of the member is dense, or even porcellaneous in texture; in places suggesting the quality of lithographic stone. It is brittle. and commonly breaks with a conchoidal fracture.

At least some of the dolomite is clastic in origin. Locally, rounded and angular grains of dolomite as much as 4 millimeters in diameter can be recognized in the subporcellaneous matrix. In other beds which show no megascopically visible evidence of granularity there is a suggestion of an obscure ghostlike arenaceous texture. Thin sections show that the grains are like the matrix in character, being composed of the same cream-colored dense dolomite. Some of the rounded grains of dolomite may be oolites.

In the upper half of the member there are a number of thin brown-weathering sandstone interbeds and many of the dolomite beds contain quartz grains. The sandstones range from $1 / 4$ inch to about 6 inches in thick- ness. They are made up of clear to milky generally well-rounded quartz grains, 1 or 2 millimeters across. The quartz grains in the sandstones commonly compose less than half of the rock, the balance being the dolomitic matrix. The quartz grains in the dolomite beds are similar to those in the sandstones.

These sandstone interbeds are lithologically identical with both the basal sandstone of the member that is found in the exposures from Black Point to beyond the Phillipsburg mine and the sandstones that comprise the overlying Oxyoke Canyon sandstone member. These thicker beds, however, in most places exhibit a prominent crossbedding that is emphasized on weathered surfaces by leaching of the dolmmite matrix, the lamellae of quartz being left in relief. The basal sandstone near faults is commonly a quartzite.

The dolomites of the Beacon Peak member form smoother more subdued slopes than the more rugged, blocky-weathering Lone Mountain dolomite below, or the cliff-forming overlying Oxyoke Canyon sandstone member. Individual beds probably average a foot in thickness; but where the dolomite is jointed, it is difficult to distinguish bedding because of the common absence of laminations in the dense dolomite.

The unconformable contact of the Beacon Peak dolomite member with the underlying Lcne Mountain dolomite has been described. The upper contact with the Oxyoke Canyon sandstone member is rather sharply gradational. To the north thick-bedded sandstones of the Oxyoke succeed the Beacon Peak dolomites with the included thin interbeds of sandstone abruptly; in Oxyoke Canyon there is, in most pleces a bed of sandstone about 5 feet thick with dolomite above and below, some 15 feet below the continuous sandstones of the Oxyoke.

The Beacon Peak dolomite member, eart of Eureka, ranges in thickness from 470 to 940 feet, the larger figures being to the north. At the type locality in Oxyoke Canyon it is 470 feet thick; just north of Black Point it is 625 feet. This figure includas 80 feet of sandstone at the base. On the ridge north of the Phillipsburg mine the total thickness has increased to 940 feet, including 225 feet of the bas 91 sandstone. Although the equivalents of the Beacon Peak and the overlying Oxyoke Canyon sandstone member have not been established by detailed mapping in the area west of Eureka, the total thickness of beds ir the interval represented by the two members at Modcc Peak, Lone Mountain, and Roberts Creek Mountain, appears to be comparable to the thicknesses in Oxyoke Canyon: the western thicknesses range from about 700 feet to 800 feet, in comparison with the combined thickness of 870 feet in Oxyoke Canyon. 


\section{OXYOKE CANYON SANDSTONE MEMBER}

The Oxyoke Canyon sandstone member takes its name from Oxyoke Canyon, where the member is exposed in several fault blocks. The type section is in the canyon along the southwest slope of Beacon Peak where an old wood road along the bottom of the canyon provides excellent exposures of the unit. The member is exposed throughout the south end of the Diamond Mountains extending from south of Hornitos Cone to Silverado Mountain and the Alhambra Hills. The member also extends in a linear band from Black Point to beyond the Phillipsburg mine on the west slope of the Diamond Mountains and in a small exposure at the east base of Newark Mountain near the Gimme mine.

West of Prospect Ridge sandstones have been recognized at about this horizon in several places, but the thicknesses are much less than to the east. Near Modoc Peak, for example, a 20-foot bed of sandstone similar to that of the typical Oxyoke Canyon member lies nearly 800 feet above the base of the Nevada formation and probably indicates an horizon not far from the top of the member in the type locality. At Combs Peak, southwest of Modoc Peak, a 15-foot sandstone bed roughly 300 feet above the base of the Nevada probably represents a tongue equivalent to beds near the base of the member to the east. No sandstone of this type has yet been recognized in the Lone Mountain or Roberts Creek Mountain sections, but they have been found in the Sulphur Spring Range to the east and northeast.

Although the dominant constituent of the Oxyoke Canyon member is a thick-bedded sandstone or quartzite, there are a few beds of Beacon Peak member type dolomite in the lower part of the nember and more abundant thicker beds of a coarsely granular dolomite in the upper part. The lower part particularly forms cliffy slopes that rise above the less resistant Beacon Peak dolomite member. West and southwest of summit 8727 in the Diamond Mountains near the north boundary of the Eureka quadrangle the outcrop of the member is characterized by especially rugged topography, and some of the steep slopes which it forms can be scaled only with difficulty.

The sandstone beds are light olive gray in color and commonly weather to shades of brown. They are composed of fine- to medium-grained rounded quartz grains in a dolomite cement. Beds are commonly several feet thick and many of them exhibit crossbedding, a feature especially striking on weathered surfaces as a result of solution of the carbonate matrix. Some of the beds in the lower portion show possible organic structures suggesting worm castings, and near the Phillipsburg mine these lower beds locally contain numerous casts of large crinoid columnals and sparse ones of a small brachiopod.

The dolomite beds in the lower part of the member are similar to those in the Beacon Peak dolomite member. The higher dolomite beds, however, are light gray to white in color, coarsely granular, and commonly vuggy. They are 3 to 5 feet thick, and in most places contain variable amounts of rounded quartz grairs.

In many places, especially where faulting has been intease, the sandstone beds of the Oxyoke Crnyon member become vitreous and quartzitic; this is especially true of beds in which the dolomitic matrix is sparse or absent. These quartzites may closely resemble the Eureka quartzite and the possibility of confusion is heightened by the fact that dark dolomites may overlie both quirtzites. If the characteristic crossbedding or the interbedded dolomites are present in such exposures, the quartzites of the Oxyoke Canyon can readily be distinguished from the Eureka; otherwise the relationships to the more distinctive subjacent formations may be needed tor identification.

The upper boundary of the Oxyoke Canyon member, like the lower one, is gradational, but the zone of gradation is somewhat thicker, probably approaching 50 feet in most places. Within this thickness of beds the proportion of dolomite to sandstone increases until dolomites make up all the section, and darkgray to black dolomites occur interlayered witl the light-gray ones. In mapping, either the hirhest sandstone bed or the lowest dark dolomite has been locally selected as the boundary.

In the eastern exposures of the member the thickness is fairly constant, with measured thicknesses of 400 feet in Oxyoke Canyon, 430 feet in the Black Point section, and 450 feet north of the Phillipsburg mine. The amounts of sandstone present in the areas west of Eureka are much less, although the total thickness of beds that are thought to be equivalent is about the same, as noted in preceding paragraphs.

\section{SENTINEL MOUNTANN DOLOMTTE MEMBER}

The Sentinel Mountain dolomite member takes its name from Sentinel Mountain at the head of Oryoke Canyon, on the lower southeast slope of which it is well exposed. Equally good sections are also found in the Alhambra Hills. Like the underlying Oxyoke Canyon sandstone member it is extensively exposed in the southern Diamond Mountains and on the we tern flank of these mountains north of Black Point. The member is also present on Newark Mountain. West of Eureka lithologically similar beds occur in many places at about the same stratigraphic position a" the Sentinel Mountain dolomite member; detailed mapping 
will be required to establish equivalence with the member, however.

The Sentinel Mountain member is entirely composed of dolomite and typically exhibits an alternation of light- and dark-colored beds. The light-gray beds are thick bedded and are commonly coarse grained and more saccharoidal in texture than the darker dolomites interbedded with them. Mottling and a faint lamination are characteristic of the darker dolomites, which in Oxyoke Canyon particularly have a high organic content and yield a strong petroliferous odor when broken. These beds are a chocolate or medium brown in color, rather than dark gray to black, in comparison with the darker dolomites in the Alhambra Hills and elsewhere. Some dark-brown petroliferous dolomites in the member where it is exposed northeast of the Phillipsburg mine contain small white corals that are similar to, but smaller than, the Cladopora-like corals which are so abundant in the stratigraphically higher Bay State dolomite member.

The contact between the Sentinel Mountain member and the overlying Woodpecker limestone member is a gradational one. The zone of gradation appears not to be at a single stratigraphic zone throughout the Eureka region, but extends, from place to place, over a thickness of several hundred feet. On Newark Mountain, for example, dolomites typical of the Sentinel Mountain member are found up to the base of the Bay State dolomite member, and the limestones of the Woodpecker member are represented by dark dolomites that resemble them texturally and faunally. One of the best places to observe the gradational contact between the Sentinel Mountain and Woodpecker members is on the ridge northeast of the Phillipsburg mine. Here a platy limestone bed similar to those in the Woodpecker occurs at least 20 feet below the contact as it was mapped; many of the dolomite beds at the top of the Sentinel Mountain are sandy and are similar in color and texture to the limestones in the Woodpecker.

In some places, especially where there has been considerable faulting which has rendered the normal stratigraphic sequence obscure or where the Woodpecker limestone member is thin or absent, the Sentinel Mountain dolomite member may be confused with parts of the Bay State dolomite member. This younger unit also contains zones of alternating light and dark dolomites and some petroliferous beds, some of which contain Cladopora. In general, however, the two can be distinguished by the more massive bedding and cliffy character of the Bay State and the generally more uniform appearance of the dolomites, as well as the common occurrence in the younger unit of the characteristic brachiopod Stringocephalus.
Because of the gradational contact with the Woodpecker member, the thicknesses assigned to the member are rather variable. Measurements of 459 feet and 410 feet were made, respectively, in the Phillipsburg and Black Point sections on the western flark of the Diamond Mountains. In Oxyoke Canyon, however, there are 595 feet of beds in the member as mapped, and these compare closely with measurements of 581 and 590 feet at two places in the Alhambra Hills. The interval represented by the Sentinel Mountain west of Eureka appears to be represented on Lone Mountain by the beds which Merriam (1940, p. 23-24) called the "crinoidal members." These total 600 fect in thickness.

\section{WOODPECKER LIMESTONE MEMBER}

The Woodpecker limestone member has its type locality in the gulch draining the south s'npe of Woodpeckers Peak, which is situated on the north boundary of Oxyoke Canyon. The member is exposed at other places in the southern end of the Diamond Mountains, notably on Sentinel Mountain and in the Alhambra Hills. It is also present on the west flant of the mountains north of Black Point; on Newark Mountain, however, it is either absent or poorly developed, its interval being occupied by dolomite. Merriam (1940, p. 24) recognized the member on Lone Mountain, where he referred to the unit as one composed of "siliceous limestones". Characteristic limestones with $\varepsilon$, typical fauna have been found on Roberts Creek Mountain and in Antelope Valley.

The Woodpecker limestone member is made up of thin- to medium-bedded limestone, which is not uncommonly sandy or argillaceous. It normally underlies saddles or strike valleys, being les resistant to erosion than the two dolomite units above and below it. There is a considerable degree of variability in both the lithologic character and thickness of the member; the calcareous nature of the unit between the two dolomites serves to distinguish it, however.

In Oxyoke Canyon the member is composed chiefly of thin-bedded platy limestones and calcareous shales. The limestones are fine grained to aphanitic or porcellaneous and are light olive gray to dark gray. Shaly partings are common, and some of the limestones have a considerable content of silt, grading into the calcareous shales. Weathering of these clay-rich beds produces pinkish or yellowish colors that help to identify the unit from a distance. Two distinctive lithologic types found in this area are a fine-grained somewhat "punky" calcareous shale containing numerous pteropods of the Styliolina type, and a dark-blue limestone with tan or buff argillaceous mottling.

In the Alhambra Hills the member is dominantly dark limestone and has a much smaller content of argillaceous material. The bulk appearance of the unit 
here is much darker than in the Oxyoke Canyon sequence, but the dark color is relieved by numerous clay or silt partings that weather a deep pink. Some of the beds are dolomitic, but one characteristic horizon near the top of the member is dark limestone whose nodular texture is the result of closely spaced crinkly partings. The member as exposed east of the Phillipsburg mine is rather similar to the occurrence in the Alhambra Hills. On Newark Mountain the proportion of dolomite has increased so greatly that the position of the Woodpecker limestone member can be recognized only by the occurrence of thin-bedded and laminated dolomite, some beds of which have a porcellaneous texture similar to that of the Woodpecker limestones. These beds furthermore contain abundant sections of the fossils that characterize the limestone beds at the other localities.

Although the lower boundary of the Woodpecker limestone member is notably gradational, the upper contact, especially in the exposures in Oxyoke Canyon and the Alhambra Hills, is quite sharp. In this area it is marked by a varying thickness of light-gray dolomite sand, which has been selected as the base of the overlying Bay State dolomite member. The sand exhibits textures that suggest deposition in a shallow sea, but the abrupt change in sedimentation probably does not indicate any significant erosion of the Woodpecker prior to deposition of the Bay State.

The thickness of the Woodpecker member, where it has been mapped, ranges from 220 feet east of the Phillipsburg mine through 450 feet in the Black Point section, 390 and 410 feet in Oxyoke Canyon and 350 feet in the Alhambra Hills. Merriam reports 450 to 500 feet at Lone Mountain. There is probably some 400 to 500 feet of dolomite in the Newark Mountain section that represents the Woodpecker interval, although it has been difficult to map the member satisfactorily in this area.

The transition from the dolomite that makes up the section on Newark Mountain to the limestones in the more westerly sections appears to be still another example of the preferential deposition of limestone westwards, presumably in the direction of the thenexisting shoreline.

\section{BAY STATE DOLOMITE MEMBER}

The uppermost member of the Nevada formation is composed of massively bedded dolomite; it is well exposed in the vicinity of the Bay State mine on Newark Mountain, and the section above the mine in Mining Canyon has been selected as the type locality. In addition to the occurrence on Newark Mountain, the Bay State dolomite member is extensively exposed in the south end of the Diamond Mountains from Wood- peckers Peak south to the Alhambra Hills and on the west flank of this range from Black Point northwards to beyond the Phillipsburg mine. Merriam has recognized beds that probably belong to the member on Lone Mountain (1940, p. 24-25), and we hare found similar strata in the Mahogany Hills, especially in the vicinity of Table Mountain to the west and from Modoc Peak southwards on the east. The unit is probably represented in the Roberts Mountains, but it appears to be absent in the southern part of the Sulphur Springs Range.

The dolomite beds that make up the Bry State member are fairly uniform in character. They are massive bedded and dark colored and normally form cliffy slopes, individual cliff steps being as much as 50 feet in height.

The basal unit in the member is a light-gray dolomite sand, which locally contains fragments or boulders of dolomite and siltstone and which exhibits somewhat irregular bedding planes that resemble the surfaces shown by poorly sorted beach sands. These dolomite sands range from 50 to 80 feet thick in the southern Diamond Mountains. The massive dolomites above are commonly dark gray to black, but many of these beds in Oxyoke Canyon have a distinctive dark-purplish-brown aspect. A characteristic feature of these massive dolomites is the occurrence within them of abundant white cylindrical corals of the Cladopora type; the field name for these dolomites is "spaghetti" dolomite, because of the resemblance of the corals to spaghetti rods. Other beds are crowded with the large brachiopod Stringocephalus, which rarely can be broken out from the coarsely granular dolomite matrix but can be observed only in section. Mottling or marbling of the dark dolomites is not uncommon and some of the beds show a faint lamination parallel to the bedding.

Near the top of the member lighter gray dolomites are interbedded with the darker layers. These somewhat resemble the alternations of light and dark dolomite found in the Sentinel Mountain dolomite member, but the beds in the Bay State dolomite member are more massive and cliff forming, and the color contrast is less sharp. At the head of Oxyoke Canyon, the Bay State member also includes beds of chocolatebrown bituminous or petroliferous dolomite that are similar to those in the Sentinel Mountain member in this canyon.

In mapping we have selected the base of the dolomite sand as the base of the member. Although the sand apparently marks some sort of break in sedimentation, it apparently has little time significance, since the beds immediately below in the Woodpecker limestone member contain a fauna that includes corals and Stringo- 
cephalus and other brachiopods that are thought to be essentially contemporaneous with the Stringocephalus beds in the Bay State dolomite member.

The contact of the Bay State dolomite member with the overlying Devils Gate limestone is, as noted above, gradational in all the localities that we have so far mapped. It is marked by the transition from thickbedded dolomite to equally thick bedded limestone and appears to occur within a zone about 50 feet thick. On Newark Mountain, especially, later dolomitization of the basal limestone beds of the Devils Gate has made selection of a precise contact difficult.

Several measurements of the thickness of the Bay State member suggest a slight thickening to the north and west, the range being from about 600 feet to 850 feet. Two measurements in Oxyoke Canyon gave 630 and 705 feet and two on Newark Mountain, 618 and 650 feet. North of Black Point on the west flank of the Diamond Mountains the member is 750 feet thick and northeast of the Phillipsburg mine, 850 feet. On Lone Mountain, the section described by Merriam (1940, p. 24) suggests a thickness of about 800 feet, and in a section on the west flank of the Mahogany Hills we found nearly 1,000 feet of beds that may belong to the member. This last figure, however, needs confirmation through detailed mapping in this area.

\section{AGE AND CORRELATION}

Several faunal zones in the Nevada formation indicate that it is of Early and Middle Devonian age. Our recent fossil collections have extended but not materially modified Merriam's study (1940) of the Devonian in the Roberts Mountains region. Merriam recognized in the Nevada, as restricted, 5 faunal zones and 1 subzone, or horizon; 2 of these were assigned to the Lower Devonian and 3, together with the subzone, to the Middle Devonian. All are now known in the vicinity of Eureka, although the lower 3 are poorly, if at all, represented east of the town.

The lowest faunal zone, the Trematospira, or Spirifer cf. S. arenosus zone (Merriam, 1940, p. 50-52) has been found in the southern Sulphur Spring Range and on the west slope of the Mahogany Hills in addition to the localities noted by Merriam in the Roberts Mountains. In both, the enclosing beds are limestones that appear to overlie coarsely granular gray dolomites similar to those in the Lone Mountain dolomite and that are stratigraphically appreciably below thin sandstones similar to those composing the Oxyoke sandstone member. The fauna has not yet been found in the part of the area in which detailed mapping has been completed, but it is believed that the beds probably are equivalent to the lower part of the Beacon Peak dolomite member. East of Eureka the Beacon Peak is nearly unfossiliferous. Our only collection, made on the eastern slope of Beacon Peak, consisted of some indeterminate gastropods.

Merriam regarded this fauna as of Early Devonian age and believed that it was certainly as low in the Lower Devonian as Oriskany. The beds in which the Spirifer cf. S. arenosus fauna occurs are provisionally correlated with the Beacon Peak dolomite member. McAllister's (1952, p. 14-17) discovery in the Quartz Spring area in California of the same Lower Devonisn fauna at the top of a dolomite similar to and correlated in part with the Lone Mountain dolomite is significant. It implies that the uppermost part of the dolomite at Quartz Spring is correlative with the Beacon Peak, the lowermost member of the Nevada formetion.

The second faunal zone was identified ly Merriam (1940, p. 52-53) as the Spirifer kobehanc zone and was reported by him to occur at Lone Mountain, in the Roberts Mountains, and at Combs Peak in the southern Mahogany Hills. All these lccalities are west of Eureka, and from what is known of their stratigraphic position in advance of detailed mapping they appear to represent horizons conside"ably below the thin sandstones thought to be westerly tongues of the Oxyoke Canyon sandstone member. Our only collection from the Oxyoke Canyon member east of Eureka was a scanty one, consisting of casts of small rhynchonellid brachiopods and crinoid columnals. It was found near the base of the sandstc ne member east of the Phillipsburg mine. The Spirifer kobehana fauna is likewise regarded as of Early Devonian (Oriskany) age and slightly younger than the Spirifer cf. S. arenosus fauna.

Merriam's third faunal zone, the Spirifer pinyonensis zone (1940, p. 53-56), although fairly widely distributed in Nevada, has so far not been found in the areas east of Eureka that we have mapped. Merrinm reported it from Lone Mountain, the Roberts Mountains, and Modoc Peak. It is now known to occur also in the southern Sulphur Spring Range, Combs Peak in the southern Mahogany Hills, and in Grays Canyon nearly due south of Eureka. At the last-mentioned three localities, as well as at Modoc Peak, the fauna is found in beds that lie a short distance below the thin sandstone beds that are believed to be western representatives of the Oxyoke Canyon sandstone member. Because of this stratigraphic position, it is probable that east of Eureka, the limestone beds containing the Spirifer pinyonensis fauna are represented by the upper part of the Oxyoke Canyon sandstone member, although it is possible that they may also bo equivalent to part or all of the Sentinel Mountain dolmmite member. The fauna is believed to be of Middle Devonian age. If, therefore, the Oxyoke in its urner part is 
equivalent to beds containing the fauna, it would appear that the member spans the boundary between Early and Middle Devonian time.

The fourth, or Martinia kirki, zone (Merriam, 1940, p. 56-57) is widely distributed both east and west of Eureka. It occurs in all the exposures of the Woodpecker limestone member east of Eureka and has even been recognized on Newark Mountain where the limestone of the Woodpecker member is largely replaced by dolomite. Merriam reports that the fauna occurs in the Roberts Mountains and on Lone Mountain; it is also present in the Mahogany Hills and in the Antelope Range. The collections from the eastern localities, which have been obtained from beds mapped as the Woodpecker limestone member, differ from those made at the unmapped western localities in the relative proportions of individual species: Martinia kirki, for example, is dominant in the western collections, but in the eastern ones Leiorhyncus nevadensis and $L$. castanea are much more numerous. Similarly, corals of the Prismatophyllum type are abundant at Lone Mountain and in the Roberts Mountains, but are absent in the eastern collections. In most of the eastern localities, moreover, the fauna lacks diversity, the number of species present being small.

Within the Woodpecker limestone member, several variations in the Martinia kirki fauna can be recognized locally. Near the base of the member, in the Alhambra Hills and in Oxyoke Canyon, the fauna is composed almost entirely of a small variety of Leiorhyncus ef. nevadensis and a small Martinia cf. kirki. Higher in the section the larger, more normal, forms of these species appear. Above the middle of the member and extending nearly to the top a large robust and narrow Schizophoria and an unusually large species of Atrypa (cf. A. independensis) occur, together with a large solitary coral assigned to the genus Moravophyllum, and a cystiphylloid.

The $M$. kirki fauna and the Woodpecker limestone member of the Nevada formation in which it occurs are both of Middle Devonian age.

Merriam (1940, p. 58) described the Heliolites horizon as a subzone or subfauna from three localities in the Roberts Mountains. A similar grouping of fossils was found at several localities at the top of the Woodpecker limestone member. It consists of Heliolites, Syringopora, "Favosites" limitaris, Moravophyllum, and Atrypa cf. A. independensis. Above the bed containing this subfauna and immediately below the dolomite sand that marks the base of the Bay State dolomite member in the Alhambra Hills, there is an exceptionally fine occurrence of the large brachiopod Rensselandia or Newberrya and in a similar position in Oxyoke Canyon, Stringocephalus n. sp. was collected.
The Heliolites horizon thus appears to be closely related in time to the overlying Stringocephalus fauna, and the range of this latter fauna therefore extends downward into the Woodpecker member.

The uppermost, or Stringocephalus, fauna of the Nevada formation (Merriam, 1940, p. 58-59) extends nearly throughout the Bay State dolomite member, as well as occurring at the very top of the Woodpecker limestone member. The fauna is a very simple one, consisting almost entirely of brachiopods assigned to the genus Stringocephalus, the digitate favositid Cladopora, and heads of Stromatopora. In a few places poorly preserved small cup corals, Syringopora, and sections of small brachiopods may be recognized. The fauna, so far as the number of genera and species is concerned, is depauperate, but certain beds may be crowded with individual specimens of the species that are repr ssented. There is a noticeable difference in maximum size and thickness of shell from one bed containing Stringocephalus to another, and it is more than likely that several species of the genus may occur in different horizons. The preservation of the shells in the dark dolomite matrix is poor, however, and it is almost impossible to remove them except in the rare occurrences where the shell is silicified.

The Stringocephalus zone in many places has a relatively limited vertical extent, Merriam (1940, p. 58-59) reporting it through only a few feet of strata on Lone Mountain and from about 75 feet of beds at Modoc Peak. In the area we have mapped, however, it extends through at least 400 feet of the Bey State dolomite member and not improbably will eventually be found throughout the member. The concept that the fauna is restricted to a very narrow intervel at the top of the Middle Devonian therefore does not seem valid.

Devonian rocks are widely distributed over the eastern Great Basin and their correlation has been reviewed by several writers in recent years (Merriam, 1940, p. 67-71; Nolan, 1943, p. 152-153; Easton and others, 1953, fig. 2). Specific correlation of many of these occurrences with the Nevada formation or its members is made difficult, however, by the lack of detailed stratigraphic and paleontologic data concerning many of the thicker sections. Much of the faunal evidence from such sections, for example, indicates crly the presence of beds that correlate with the Devils Gate limestone, which overlies the Nevada, althorigh the thicknesses reported are such that beds of Nerada age might also be present.

East of Eureka, the Sevy, Simonson, and Guilmette formations at Gold Hill (Nolan, 1935, p. 18-21) probably can be directly correlated with the Nevada formation, although it is likely that the uppermost beds of 
the Guilmette may eventually be shown to be more closely related to the Devils Gate limestone. The Sevy dolomite is lithologically identical with the Beacon Peak dolomite member of Eureka; it is probable that this dense light-colored dolomite is widely distributed in eastern Nevada and western Utah. The Ruby Range section described by Sharp (1942, p. 661-664) also contains beds that appear to be equivalent to those in the Nevada formation at Eureka. Sharp's detailed section is thought to include beds that can be correlated with the Sentinel Mountain dolomite, Woodpecker limestone, and Bay State dolomite members.

Almost all the remaining direct correlations in adjoining areas are to the south. McAllister (1952) found faunas nearly identical to the Spirifer cf. S. arenosus and Spirifer kobehana faunas of this report in the upper portion of his Hidden Valley dolomite in the Quartz Spring area of California, and the lower part of his Lost Burro formation, which overlies the Hidden Valley dolomite, is lithologically similar to the upper portions of the Nevada formation at Eureka. Kirk (1927, p. 220) reports a Stringocephalus fauna from strata in the northern Spring Mountains; and recent work by M. S. Johnson and D. E. Hibbard (1956) at the Mercury Test Site shows that a section that resembles the Nevada formation in many respects occurs there.

Perhaps the most striking correlation that can be made with the Nevada formation lies to the north in Canada. Faunal evidence accumulated in recent years by Warren and his coworkers (Warren, 1944; Warren and Stelck, 1949) shows that there must have been a nearly continuous seaway between the Mackenzie and Great Slave Lake regions and central Nevada throughout much of Devonian time.

\section{DEVILS GATE LIMESTONE}

The Devils Gate limestone was defined by Merriam $(1940$, p. 16-17) as the upper division of the thick Devonian sequence to which Hague gave the name Nevada limestone. Devils Gate, about 9 miles northwest of Eureka and along the northern boundary of the area mapped by Hague, was chosen by Merriam as the type locality. In the original description the formation was defined almost wholly on the basis of faunas: the lower boundary was placed at the top of the faunal zone containing Stringocephalus, and the upper one was marked by the disappearance of the Cyrtospirifer ("Spirifer disjunctus") fauna.

The recent mapping which we have accomplished in the Eureka and Pinto Summit quadrangles, immediately east of the area studied by Merriam for his 1940 monograph, indicates that there is an adequate lithologic basis for establishing the Devils Gate limestone as a separate stratigraphic unit consistent with the paleontologic definition. Throughout the Diamond Mountains from north of the Phillipsburg mine to the Alhambra Hills, the Bay State dolomite member of the Nevada formation is overlain by a thick sequence of rather massive limestones that are easily distinguishable both from the Bay State dolomite member below and the calcareous shales of the overlying Pilot shale. We have been able to map this limestone and in most places to distinguish two members within it. Berause of the dominantly calcareous nature of the formation we have used the name Devils Gate limestone, rather than Devils Gate formation.

In addition to the occurrences in the Diamond Mountains and at the type locality of Devils Gate the formation occurs at Lone Mountain and throughout the Mahogany Hills. It appears to be absent in the Roberts Mountains and over most of the southern portion of the Sulphur Spring Range. One of the best exposures of the unit is on Newark Mountain in the southeast portion of the Eureka quadrangle, where the formation makes up the upper portion of the impressive eastward-facing scarp that rises nearly 2,000 feet above Newark Valley.

The Devils Gate limestone is composed in large part of thick-bedded gray to blue-gray limestone that is cliff forming in most places. Some thirner bedded limestones that are platy or flaggy are interbedded with the more massive beds, but they are not abundant and are concentrated, for the most part, ir the middle or at the top of the formation. Many of the thickbedded limestones, however, contain aburdant thinly spaced argillaceous laminae that are chare steristically somewhat crinkly rather than planar. Lorally, where weathering is more advanced than normally is the case, these serve as parting planes.

The limestone that makes up the greater part of the Devils Gate is relatively free from clay or silt, except for the local thin argillaceous partings, and is hard, dense, and brittle. It is medium gray to dark gray on fresh fracture and weathers to light colors, not infrequently to a light bluish gray. Cliff surfaces especially may yield, on weathering, solution-pitted or fluted faces that are mottled by a pale tan veneer.

Dolomites or dolomitic limestones are uncommon, though some occur at the base and near tl a middle of the formation.

The cliffy habit of the Devils Gate limestones, together with the prevailing lighter color of the outcrops, makes the formation rather easily distinguishable at a distance from the much darker dolomites of the underlying Nevada formation, which moreover produces a blocky steplike profile that contrasts with the cliffy slopes of the Devils Gate. The Devils Gate limestone on Newark Mountain also differs from the 
Nevada in the presence of numerous caves and recesses; these have formed much more readily in the limestone than in the less soluble dolomite. 'The contrast with the overlying Pilot shale is even more striking: the shale has a pronounced pinkish color on the weathered surfaces and forms a subdued topography, usually in the nature of dip slopes or strike valleys.

Although the contact between the Devils Gate limestone and the Nevada formation is readily recognized from a distance, it is gradational when examined in detail, as has been noted. It is marked by a change from dolomite to limestone within a transition zone ranging from about 30 to 75 feet in thickness. At.no point was a sharp break observed, and even above the transition zone there are sporadic light-gray laminated dolomite beds. In general, the base of the Devils Gate was placed at the lowest bed of dark-gray thickbedded limestone. The upper contact of the Devils Gate limestone with the Pilot shale is sharp and easily distinguished. It is marked by the change from wellbedded cherty fossiliferous limestone to pinkishweathering calcareous shales.

On Newark Mountain and in the southern end of the Diamond Mountains two members of the Devils Gate limestone may be distinguished: a lower Meister limestone member and an upper Hayes Canyon limestone member. These two units were not recognized either in the Diamond Mountains north of Diamond Peak or in the Lone Mountain or Mahogany Hills exposure.

The thickness of the Devils Gate limestone ranges from about 675 feet east of the Phillipsburg mine in the Diamond Mountains, to 2,065 feet in the combined sections at Devils Gate and Modoc Peak (Merriam, 1940, p. 16). A partial section on Lone Mountain includes more than 1,100 feet of beds; a complete one on Newark Mountain, about 1,200 feet; and another complete one in the Diamond Mountains northeast of Black Point, 750 feet. The paleontologic evidence suggests that this decreased thickness to the east and north may be in part due to the replacement of the higher beds of the Devils Gate to the west by the Pilot shale eastward. It is unlikely, however, that the full amount of the variation in thickness is due to this; an appreciable amount of the eastward diminution seems to be the result of either nondeposition or to a slower rate of deposition in this direction. We have not found any evidence that the decrease in thickness was caused by emergence and erosion at either the beginning or the end of Devils Gate sedimentation.

\section{MEISTER MEMBER}

The lower, or Meister, member of the Devils Gate limestone takes its name from the Meister mine on Newark Mountain, in the vicinity of which the member is well exposed. It has been separately mapped tr roughout Newark Mountain and in the southern end of the Diamond Mountains between Woodpeckers Per,k and the Alhambra Hills.

The greater part of the member, above the transitional zone with the Nevada formation, is made up of thick-bedded gray fine-grained limestones similar to those found throughout the Devils Gate limestone. Many of the beds are crowded with rounded algal growths or stromatoliths, and others are filled with colonies of the coral Cladopora sp.

The occurrence of beds of dolomite and dolomitic limestone, together with the sparse occurrence of fossils other than the concentrations of Stromatopora and Cladopora, are the distinctive features of the member. Some of the dolomites occur in the gradational zone a.t the bottom of the member and are dark granular dolomites similar to those in the Bay State dolomite member. A few dolomites also occur sporadically throughout the member. The most significant ones, however, o?cur in a 30 -foot zone at the top of the member. These are white-weathering dense dolomites or dolomitic limestones, in beds 6 inches or so thick which are interbedded with darker limestone beds of the same thickness. Some of the beds in this zone show a fine lamination, and in places there are thin interbeds of pinkishweathering clay or silt. This zone of flaggy dolnmitic and limy beds is overlain br a dark-gray oolitis limestone that contains ostracods and is the base of the overlying Hayes Canyon member.

The lower 150 feet of the member is commorly cliff forming and stands out prominently above the less precipitous slopes formed by the upper portion of the Bay State dolomite member of the Nevada forration. The alternating dolomite and limestone zone at the top of the member, on the other hand, is less resistant to erosion than the beds above and below; its outcrop in many places is marked by a bench.

The member is 410 feet thick on Newark Mountain. Approximately the same thickness is thought to be present to the south in the southern end of the Diamond Mountains, but no complete sections have been measured there.

\section{HAYES CANYON MEMBER}

The upper member of the Devils Gate limestone is composed exclusively of limestone. It is well exposed along the crest of Newark Mountain and is named from Hayes Canyon, ${ }^{11}$ which drains the west slope of the Mountain. Other exposures of the member are found to the south, where some especially well exposed sequences may be found in the Alhambra Hills.

\footnotetext{
${ }_{11}$ Hayes Canyon is the name used by Hague in Monograph 20 for this drainage feature. The recently prepared Eureka quadrangle uses Tollhouse Canyon, which conforms to present-day usage.
} 
Like the Meister member most of the Hayes Canyon member is made up of the thick-bedded limestones that characterize the whole formation. These have the same cliffy habit as those in the Meister and contain similar biostromes of Stromatopora and Cladopora.

The Hayes Canyon member can be distinguished from the Meister member by beds of characteristic lithologic character at the top and bottom and by the presence of abundant fossils in the upper third of the unit.

The diagnostic bed at the bottom of the member is the dark-gray oolitic limestone containing ostracods, which has been noted above. This fine-grained rock is crowded with tiny inclusions with the shape of a wheat grain that are less than 2 millimeters in length. Some of these nodules are encrusted ostracods; the others, which are commonly smaller, are oolites and appear to be phosphatic. The matrix is an argillaceous limestone that in most places weathers to shades of pink. Near the Bay State mine, a 30-foot thick limestone bed that weathers white occurs above the ostracod bed. This is a very dense, almost porcellaneous rock that is a uniform medium dark gray on fresh fracture.

The upper 150 feet or so of the Hayes Canyon member is thinner bedded and somewhat darker colored and in many beds contains stringers or lenses of dark chert. The beds average about a foot in thickness and commonly occur on the back slopes of the cliffforming more massive limestones. In this zone also there are sporadic intraformational or mud-breccia conglomerates. These are especially common at Devils Gate.

Many of the limestones in the upper 300 feet are highly fossiliferous and thus contrast with the lower beds. Gastropod sections are especially common in the lower part of this zone, and brachiopods are found throughout, those in the upper beds being locally silicified.

A section of the member measured in the northern part of Newark Mountain was 780 feet thick. At least an equal thickness appears to be present on the eastern slope of the north end of Silverado Mountain.

\section{AGE AND CORRELATION}

The Devils Gate limestone is of Middle and Late Devonian age, the time boundary apparently lying in the upper half of the Hayes Canyon limestone member. In his original description of the formation, Merriam (1940, p. 59-61) recognized three faunal zones: one of late Middle Devonian age and the other two of Late Devonian age. Recent work has demonstrated the presence of three additional zones, all of them falling below the zones previously established. One of these new zones occurs in the lower part of the Meister member; a second at the base of the Hayes Canyon member; and the third, low in the upper half of that member. Not included in these zones are the assemblages of tabulate corals of the Cladopora type with stromatoliths or stromatoporoids; these are abundant in both the Meister and Hares Canyon members. The coral and algal assemblage together with the sections of Atrypa-like brachiopods that are locally associated with them are of little value so far as specific age determinations are concerned, although they do provide presumptive evidence of Devonian age in the Great Basin.

The lowest faunal zone is found sporadically in the lower 200 feet of the Meister member; it is characterized by solitary tetracorals of medium to rather small size which are tentatively referred to Macgeea subcylindrica Stumm; with Macgeea is anther coral assigned to Disphyllum nevadense Stumm and a thickwalled digitate favositid of the Thamnopora type, which is long-ranging in this formation. TRrachiopods consist in the main of Atrypas of nonspinose type, such as occur through much of the formation. This fauna has not been found in the sections west of Eureka. It is believed to be of Middle Devonian age.

The second faunal zone occurs in the limestone at the base of the Hayes Canyon member. It is composed of ostracods which, while numerous, appear to include relatively few forms. The fauna has not yet been carefully studied, but most of the species are thought to belong in the Leperditia group. Walcott (1884, p. 204-206) described two species of ostracods from the Devonian which perhaps came from this faunal zone, since the localities which he cites are in places in which we have mapped the Hayes Canyon member. We have found this fauna only in the mapped areas east of Eureka. It is regarded as being of Middle Devonian age.

The third faunal zone is found about 50 ? feet above the base of the Hayes Canyon member, both at Newark Mountain and in the Alhambra Hills; it has not been recognized to the west. The characteristic form is a brachiopod, provisionally assigned to Ty'othyris, one of the narrow spiriferoids with high cardinal area occurring widely in Middle and Upper Devonian strata in the Cordilleran region. The zone is tentatively placed near the top of the Middle Devonian.

The lowest of the faunal zones established by Merriam $(1940$, p. 59) at the type locality, the Spirifer argentarius zone, is widespread east of Eureka as well. In the eastern localities the fauna appears to be limited to about 100 feet of beds that is some 125 feet below the top of the Hayes Canyon member. This is in contrast to the situation at Devils Gate, where the 
fauna has a vertical range of about 800 feet. This pronounced thinning eastward may simply be in response to the stratigraphic thinning in this direction that has been noted, but it is also possible that the thicker zone at Devils Gate may include the Tylothyris zone that has been separately distinguished to the east.

The Spirifer argentarius zone is rather limited in the number of species it includes, the principal ones being $S$. argentarius, Tenticospirifer utahensis, abundant Atrypas of the montanensis and devoniana types and a rare tetracoral assigned to Mictophyllum Lang and Smith. At the type section of the Devils Gate limestone, the lower part of the zone yielded Hypothyridina sp. a. (Merriam, 1940, p. 59), but this form has not been found in the more easterly collections.

What may be a subzone of the $S$. argentarius zone was found in the Alhambra Hills. This occurs between strata containing Tylothyris and beds containing $S$. argentarius. It is characterized by Spirifer engelmanni in association with Orecopia (Platyschisma) mecoyi (Walcott). The latter form is rather widely distributed in the Hayes Canyon member east of Eureka and probably has a rather large vertical range, although in most of the places where it occurs it appears to be the only fossil present.

In his original discussion of the $S$. argentarius fauna, Merriam (1940, p. 59) assigned it to the latest Middle Devonian. Recent study of related faunas in western Canada suggests, however, that $S$. argentarius is a fairly reliable indicator of a widely recognizable zone in the lower part of the Upper Devonian, roughly Portage in age. If a somewhat arbitrary line is to be drawn between Middle Devonian and Upper Devonian strata in the Cordilleran area, it might be best to place it below the present known range of the $S$. argentarius fauna. The boundary, so far as Eureka is concerned, is thus based on paleontology solely, for there appears to be no stratigraphic evidence of a lithologic change in the upper portion of the Hayes Canyon member.

The next to the highest faunal zone in the Devils Gate limestone is the Martinia nevadensis zone. This is the equivalent of the Phillipsastraea zone established by Merriam (1940, p. 59-61) at Devils Gate. In the localities east of Eureka, the fauna is found in 10 feet of strata at the top of the Hayes Canyon member; west of the town its position is some 250 feet below the top of the formation. There are other differences between the eastern and western collections from the zone: the western collections are relatively richer in corals and poorer in brachiopods than the eastern ones; Hypothyridina emmonsi, a distinctive brachiopod, has been found only to the west; and Martinia nevadensis is not known from the type locality, although it does occur to the south, east of Yahoo Canyon (Walcott. 1884, p. 139-140).

In addition to the species listed by Merriam (1940, p. 60) the fauna is now known to contain representatives of the following forms, which are largely undesrribed: Martinia nevadensis, Schizophoria sp., Leptostrophia sp., Dalmanella (large form), Atrypa (medium tc large, non spinose cf. A. devoniana Webster), Pugnoides, a coarsely ribbed spiriferoid with narrow hinge line like Brachythyris, Tabulophyllum, Macgeea, Displyllum, and Thamnopora.

The $M$. nevadensis zone is of Late Devonian age.

The highest faunal zone in the Devils Gate lim estone is the Cyrtospirifer zone (Merriam, 1940, p. 61). At Devils Gate and in Yahoo Canyon to the south this zone occurs at the top of the formation. We have not recognized it during the mapping east of Eureka in the Diamond Mountains; if the correlation of the Martinia nevadensis fauna with the Phillipsastraea fauna at Devils Gate is correct, then it seems fairly certain that the zone in which the Cyrtospirifer fauna occurs in the west is represented by the basal beds of the Pilot shale to the east. A conodont fauna such as occurs in the lower part of the Pilot shale has not yet been fo'md in association with Cyrtospirifer at Devils Gate; if one should be found, it would provide needed proof of this suggested correlation.

Merriam (1940, p. 61) has listed the commonest forms of the Cyrtospirifer fauna. It is of Late Devonisn age.

Rocks equivalent to the Devils Gate limestone are rather widespread in the western United States, although the reported occurrences all seem to be north, east, or south of Eureka. Nearest at hand is the section in the Ruby Range described by Sharp (1942, p. 664-667). Many of the lithologic and faunal zones recognized at Eureka appear to be present in the Ruby Range, although Sharp's two divisions differ frcm the two members established at Eureka. His lower division includes strata at the top containing the $S$. argentarius fauna and hence includes beds that wo have placed in the upper or Hayes Canyon member. Sharp mentions $(1942$, p. 664) an oolitic limestone in the middle of his lower unit; this may correspond with the bed we have made the basal bed of the Hayes Canyon.

The Devils Gate limestone is also represented at Hamilton (Humphrey, 1956), and some of the corals figured by Stumm (1942) came from there. The fauna listed by Spencer from Ely $(1917$, p. 25), which he collected from a thick section mapped as the Nevada limestone indicate that the enclosing beds are correlative with the Devils Gate limestone as here defined. There is a similar occurrence of Devils Gate faunas at Pioche (Westgate and Knopf, 1932, p. 16-19). In 
southern Nevada and southeastern California the Devils Gate seems to be represented at Goodsprings (Hewett, 1931, p. 13-16), Frenchmans Flat (Johnson and Hibbard, 1956), Nopah Range (Hazzard, 1937, p. 328-331), and the Quartz Spring area (McAllister, 1952 , p. $18-20$ ).

Eastward the Devils Gate is represented by the upper part of the Guilmette formation at Gold Hill, Utah (Nolan, 1935, p. 20-21) and the upper part of the Jefferson dolomite and all of the Three Forks limestone of northeastern Utah and southeastern Idaho (Merriam, 1940 , p. $67-71$ ).

As is true of the Nevada formation, the Devils Gate faunas are especially widely distributed to the north in northwestern Montana (Laird, 1947, p. 453-459; Berry, 1943, p. 12-14; Baldwin, 1943) and in the Canadian Rockies (Warren, 1942, 1944, 1949). Although the stratigraphic and paleontologic evidence from these localities does not appear to be wholly consistent with our findings at Eureka, it is likely that they will provide the closest analogies with the Eureka Devonian section.

\section{DEVONIAN AND MISSISSIPPIAN SYSTEMS PILOT SHALE}

The lowest beds of the White Pine shale, as defined by Hague (1892, p. 68-69), differ in lithologic character from the rest of the beds that were assigned to that unit and appear to be equivalent in stratigraphic position and relationships to the Pilot shale of the Ely district (Spencer, 1917, p. 26). In the vicinity of Eureka these lowest beds of shale in most places lie between massive limestones of the Devils Gate limestone and the Joana limestone. On the south side of Diamond Peak and locally on the west slopes of the Pancake Range, however, the Joana is absent, and the basal shales of the Chainman shale rest directly upon shales that are believed to be assignable to the Pilot.

The Pilot shale was recognized and mapped only in the region east of Eureka, where there are four narrow bands of outcrop. The most northerly band extends from the north edge of the Eureka quadrangle southwards about to the latitude of Black Point, high on the western slope of the Diamond Mountains. A second band is found along the western base of Newark Mountain, the third at the western edge of Packer Basin, and the fourth on the western flank of the Pancake Range in the southeast comer of the Pinto Summit quadrangle.

The Pilot shale is a platy shale and contrasts with the harder and darker Chainman shale. Much of it is calcareous, especially at the base. Freshly broken fragments are dun colored to black, but the rock weathers to shades of pinkish or light yellow brown to gray; in this respect also it differs from the Chainman shale.

Where exposures are good, two units can be distinguished in the Pilot shale. The lower one, which makes up a third or more of the formation is more calcareous, and some of the beds are thin bedded shaly limestones rather than platy calcareous shales. The color of this part of the section is prevailingly lighter, and the pinkish or reddish cast assumed by the lower beds on weathering is characteristic and permits easy recognition of the boundary between the Devils Gate limestone and the Pilot shale. A sandy limestone in the lower part of the unit contains a conodont fauna over most of the outcrop areas. The upper unit is lithologically more uniform; it is a yellowish-brown or dark-grayweathering black platy shale, which in most places is calcareous, although appreciably less so than the basal unit.

The lower boundary of the Pilot shale with the darkblue bedded limestone of the Devils Gate is sharp, but there is no evidence of unconformity at the contact. The contact with the basal limestone of the overlying Joana is similarly sharp. There are, hovever, platy black shales, similar to those in the upper part of the Pilot shale, between the upper and lower limestone beds of the Joana in Tollhouse Canyon just west of the summit of Newark Mountain.

The thickness of the Pilot shale, in the Diamond Mountains ranges from about 315 feet in Packer Basin to 425 feet in Water Canyon a few miles to the north. At the north end of the Eureka quadrangle, east of the Phillipsburg mine, the thickness decreases to 360 feet, and in Tollhouse Canyon, south of Water Canyon, we measured 350 feet. The lower unit is fairly consistent in its thickness, ranging in thickness in tl ree sections measured from 120 to 160 feet. These figures are comparable to those recognized by Hague (1892, unit 3 of section on p. 81 , and unit 4 of section on p. 82) but are somewhat greater.

A poorly exposed section in the Pancake Range is appreciably thicker, an approximate measurement approaching 1,000 feet in thickness. It is probable, however, that the formation, like the Chainman shale above, has localized fault movement within it and that such variations in thickness result in considerable part from structural disturbance rather than from original stratigraphic changes.

\section{AGE AND CORRELATION}

The only fossil collections from the P:lot shale in the area studied by us indicate a Late Devonian age for the formation, but the stratigraphic relations which it exhibits with the overlying Joana limestone, as well as paleontologic evidence from nearby districts, 
suggest that beds of early Mississippian age are also present in the upper part of the formation. We have therefore classified the Pilot shale as of Devonian and Mississippian age.

Several collections have come from the lower unit of the Pilot shale. Hague (1892, p. 81) reports a small collection of Devonian brachiopods from the west side of Packer Basin, and we made a small collection of linguloid brachiopods from east of Bold Bluff that were not chronologically helpful to either J. S. Williams or G. A. Cooper, of the U. S. National Museum. Most of our collections have come from a thin limestone bed in the lower part of this unit and contain a conodont fauna. These collections have been studied by W. H. Hass (1954, written communication), who reports on them as follows:

Collection 7/30/51 \#6-30'. East side of Newark Mountain, White Pine County, Nev. Measured section of $7 / 30 / 51$ at Station \#6-30'. From the platy limestone of the conodont zone. Collector: C. W. Merriam. July 30, 1951.

Most of the specimens in the collections are fragments.

Ancyrodella ef. A. curvata Branson and Mehl.

Bryantodus.

Hindeodella.

Palmatolepis n. sp. A.

Palmatolepis n. sp. B.

Polygnathus.

Prioniodus.

Collection 8/1/51 \#3. East of Eureka, in Water Canyon on the east side of Newark Mountain, White Pine County, Nev. From a pinkish platy arenaceous limestone of the Pilot shale. Collector: C. W. Merriam. Aug. 1, 1951.

Ancyrodella ef. A. curvata Branson and Mehl.

Bryantodus.

Hindeodella.

Icriodus.

Palmatolepis n. sp. A.

Palmatolepis n. sp. B.

Polygnathus pennata Hinde. Prioniodus.

Collection ES-51-8F. Tollhouse Canyon, White Pine County,

$\mathrm{Nev}$. Large piece of platy limestone.

Ancycrodella ef. A. curvata Branson and Mehl.

Bryantodus.

Hibbardella.

Hindeodella.

Ligonodina.

Nothognathella.

Palmatolepis n. sp. A.

Palmatolepis n. sp. B.

Polygnathus of. P. linguiformis Hinde.

Polygnathus cf. P. pennata Hinde.

Prioniodus.

Many of the generically identifiable specimens belong either to Ancyrodella or to Palmatolepis. These two genera as well as Icriodus are considered to be good indicators of the Middle and Upper Devonian. Most of the specimens belonging to the genera Ancyrodella, Palmatolepis, and Polygnathus resemble those present in beds considered to fall in the lower half of the
Upper Devonian. Specimens herein listed as Pa!matolepis n. sp. A have characteristics that suggest a relation ;hip with Palmatolepis subrecta Miller and Youngquist, and those listed as Palmatolepis $n$. sp. B have characteristics that suggest a relationship with Palmatolepis unicornis Miller and Youngquist. These two species are present in the Devonian-Misissippian black shale sequence of the interior of the United States in beds that are classified as coming from the lower half of the Upper Devonian. The specimens identified as Ancyrodella ef. $A$. curvata $\mathrm{B}$ ranson and $\mathrm{Mehl}$ resemble some fragmentary specimens present in the basal beds of the Upper Devonian Chattanooga shale of ce ntral Tennessee. Those identified as Polygnathus cf. $P$. linguiformis resemble Polygnathus linguiformis Hinde in having transverse ridges across the distal end of the plate, but the few specimens present in Merriam's collections are more elongate th an Hinde's species. Polygnathus linguiformis Hinde is known to range throughout much of the Middle Devonian and the lowermost beds of the Upper Devonian. Pclygnathus pennata Hinde is found associated with $P$. linquiformis in the black shale sequence of the eastern interior of the United States.

It is my opinion that the collections herein reported on come from beds that are at least pre-basal Cassadaga stage. This opinion is based on the fact that the Gowanda shale member of the Perrysburg formation of western New York is known to contain a younger conodont fauna. Throughout the interior of the United States conodonts like those present in the Gowanda are always found in beds that overlie the ones containing the conodont species mentioned in the first paragraph of this report. Hence, it is suggested that the material examined came from beds that fall somewhere in the lower half of the Upper Devonian.

The upper unit of the Pilot shale has so far proved to be unfossiliferous. Lithologically similar black shales occur in the overlying Joana limestone of Madison (early Mississippian) age, however, and suggest that there is little difference in age between the two. The Devonian and Mississippian boundary may thus be hidden within the Pilot shale. This suggestion appears to beistrengthened by the presence of Mississippian fossils southeast of Ely, Nev., in interbedded limestones and shales which are believed by Roberts $(1942$, p. 300) to be near the base of the Joana limestone. The fauna includes several specimens of Spirifer centronatus Winchell, as well as trilobites of Mississippian aspect. Both J. S. Williams and G. A. Cooper regard the collection as being of Mississippian age.

Aside from the Ely district, the type area of the formation, there is little published information concerning correlations of the Pilot shale. Unpublished data obtained in recent years by petroleum geologis's, however, indicate that this shale probably is fairly widely developed in east central Nevada and west central Utah. At Gold Hill, Utah, on the other hand, comparable rocks a re absent, and in one of the thrust plates exposed there upper Mississippian rocks rest directly on the Middle $\mathbf{D}$ evonian, indicating that in thir region at least, there was uplift and erosion in pre-late Mississippian time. 


\section{CARBONIFEROUS SYSTEMS}

Although there are no sedimentary rocks of known Mississippian or Pennsylvanian age in the thrust block that has brought western facies sediments into the Eureka region, the Carboniferous rocks of the eastern facies alone show a very wide range of lithologic character and thickness. These variations are probably due chiefly to the proximity of a land mass that was situated not far to the west and that appears to have been subject to recurrent uplift throughout much of Carboniferous time. The stratigraphic effects of the successive uplifts, however, have been intensified near Eureka by thrust faulting of smaller magnitude than the Roberts Mountains thrust. The section of Carboniferous rocks south of Eureka, for example, is very different from the one at Diamond Peak, just a few miles to the northeast; the proximity of these different sequences is believed to be caused by a belt of thrust faulting east of and presumably structurally below the Roberts Mountains fault.

Understanding of this variability in facies, together with the recent recognition of a thick Mesozoic unit of fresh-water origin, and an earlier reinterpretation of the fossil evidence (Girty, 1905, p. 11-14) have led to material changes in the Carboniferous section as described by Hague. We have used the name Joana limestone first proposed by Spencer (1917, p. 26) in the Ely district for the lowest Carboniferous formation, which is a discontinuous thin limestone unit of Madison or early Mississippian age. Above it is a thick sequence of shale, sandstone, and conglomerate, with subordinate limestone. This can locally be subdivided into a lower dominantly black shale unit, which has been referred to the Chainman shale, and an upper formation containing thick sandstones and conglomerates for which Hague's name, Diamond Peak formation, has been retained. Both are assigned to the upper Mississippian. Throughout the Diamond Mountains, including Hague's type locality of the Diamond Peak formation, the contact between these two units is gradational, and the lithologic change occurs through so great a thickness of beds that we have not been able to select a satisfactory boundary for mapping. In this area, therefore, the beds have been grouped as "Chainman-Diamond Peak formations undifferentiated." The uppermost Carboniferous formation is a thick limestone, of Pennsylvanian age, which was called the Lower Coal Measures limestone by Hague, but for which the name Ely limestone, from the Ely district, seems more satisfactory, though the age range may not be precisely the same as that of the Ely. We have not recognized Hague's Weber conglomerate, which is now believed to be largely of Mesozoic age, and we here assign his Upper Coal Measures limestone to the Permian (?).

\section{MISSISSIPPIAN SYSTEM}

JOANA LMMESTONE

The Joana limestone was first defined by Spencer (1917, p. 26) in the Ely district, about 65 miles south of east from Eureka. Together with the overlying and underlying shales, it had previously been placed by Lawson (1906, p. 296) in the White Pine shale. The White Pine was originally described by Hague (1883, p. 266-267; 1892, p. 68-70) and Walcott (1884, p. 5-6, 283-285) in the reports on the Eureka mining district, but with its type locality in the White Pine mining district. The Joana was not separs.tely mapped in this early work, although the unit was clearly recognized in a section measured in Packer Basin, southeast of Eureka (Hague, 1892, p. 81). It is not clear from this reference, however, if Hague intended to include the Joana with the underlying Devonian sedimentary rocks, or with his White Pine shale.

Within the area covered by this report the Joana occurs only east of Eureka. We have mapped it along the western margin of Packer Basin, which lies north and east of the Silverado Mountain and south of the Pinto Creek Ranch; in Tollhouse Canyor, where it is apparently discontinuous; in the Diamond Mountains, north of Diamond Peak and west of the ridge line; and on the western slope of the Pancake Range in the southeastern corner of the Pinto Summit quadrangle.

The Joana limestone, as exposed in the Eureka area, is made up of dense porcellaneous limestone, coarsely crystalline sandy crinoidal limestone that is locally somewhat conglomeratic, nodular cherty limestone, black platy shale, thin quartzite or sandstone beds, and subordinate black chert. The sequence and relative amounts of each appear to be different in each of the main outcrop areas. In the three northern areas especially, the presence of interbedded platy shales, similar to those in the underlying Pilot shale, appears to be the rule.

The most characteristic component of tr e Joana, and the one that in general appears to have the widest distribution, is a crystalline "crinoidal" limestone, commonly coarse grained but in places rather fine grained and containing abundant crinoid columnals. Locally the crinoidal limestone also contains yellowbrown shale pellets or fragments, and in a few places there are small pebbles of quartzite and chert. Smaller, but abundant fragments of unidentifiable fossils make up much of the matrix of this rock, which is normally black on fresh fracture, but which weathers to a lighter gray.

In addition to the crinoidal limestones, beds of a dense blue porcellaneous limestoneoccur in the formation as well as thin beds of cherty and sandy limestones. 
Some of the latter are lithologically not unlike beds near the top of the Devils Gate limestone.

Beds of black chert appear to be present in most well-exposed sections of the Joana. One such bed in Tollhouse Canyon is 8 feet thick.

The interbedded shales are dark gray to black, highly fissile, and commonly somewhat calcareous. They are closely similar to those at the top of the underlying Pilot shale and differ notably from the harder, blacker, and less fissile black shales in the overlying Chainman shale.

In the exposures of the Joana at the south end of Tollhouse Canyon the limestones are bleached and recrystallized to a coarsely granular limestone. Shearing and minor faulting are common owing to deformation accompanying the folding of the unit around the south end of Newark Mountain.

The contact between the Joana limestone and the underlying Pilot shale is gradational in the Diamond Mountains localities; in these it has been taken as the base of the lowest limestone bed. In the Pancake Range, where interbedded shales are less abundant in the Joana, the boundary is marked by thin sandstone or quartzite beds. The contact of the Joana with the overlying Chainman shale is, in contrast, sharp. It is almost certainly an erosional surface, and there are notable variations in the thickness of the Joana beneath it within short distances. Good exposures of this contact may be found in Tollhouse Canyon and north and south of summit 6585 near the southeastern edge of the Pinto Summit quadrangle.

The Joana limestone is absent on the south slope of Diamond Peak but reaches a thickness of 135 feet on the west slope of the Pancake Range. In the Packer Basin area, east of Island Mountain, 125 feet was measured; the section here includes at least 6 limestone beds, separated by shale. A poorly exposed section in the head waters of the canyon east of the Phillipsburg mine is 115 feet thick and includes 2 prominent limestone beds. One of the best exposures of the Joana is in the central part of Tollhouse Canyon, where 84 feet was measured. Here there is at the base an 18-inch-thick black crinoidal limestone. It is overlain successively by $3 \frac{1}{2}$ feet of dark gray silty calcareous shale; 8 feet of black chert; 35 feet of black dense cherty and platy shale; and the main limestone bed, 36 feet thick. Less than half a mile farther north, however, the whole of the Joana has disappeared.

\section{AGE AND CORRELATION}

Spencer (1917, p. 26) reported no diagnostic fossils in the Joana in the type locality of the formation, and Hague and Walcott seem not to have made any collections from it in the one place that they appear to have recognized it (Hague, 1892, p. 81). The first definite faunal evidence of the age of the Joana appears to have been obtained by G. H. Girty, who in 1930 made a collection from the formation in Tollhouse Canyon.

This collection contains an assemblage that $r$ sembles very much the fauna of the Madison limestone, of early Mississippian age. Forms that can be provisionally identified are a Spirifer resembling S. centronatus Winchell; several productoid genera, mostly immature forms; a Chonetes, probably $C$. loganensis Hall and Whitfield; and specimens tentatively assigned to Schuchertella sp., Camarotoechia sp., Compo:ita sp., Lingula sp., and Torynifer sp. An indeterminate horn coral, fragments that possibly belong to other corals, an indeterminate coiled cephalopod, and a trilobite that is either a Phillipsia or a closely related genus are also present.

Girty also made two small collections from the type area of the Joana subsequent to Spencer's work. These contain a coral, identified by Miss Helen Duncan as Syringopora cf. S. surcularia Girty, and a straparollid gastropod, possibly of the type referred to the subgenus Euomphalus. Both are consistent with an age assignment of early Mississippian for the Joana.

We have made a collection from the basal limestone of the Tollhouse Canyon section. Charles Merriam has identified the following forms: Shumardella cf. S. missouriensis (Shumard), Athyris monticola (White), Rhynchopora sp., cf. $R$. pustulosa (White), Productus cf. $P$. blairi Miller, Spirifer centronatus Winchell?, and Proetus cf. $P$. peroccidens Hall and Whitfield.

The Pancake Range exposures are highly fossiliferous. Collections made from the formation on either side of the road north of summit 6585 that crosses the range appear to represent a slightly differert fauna from that found in Tollhouse Canyon. Forms recognized include: Syringopora cf. S. surcularic Girty, Leptaena sp. undet., Chonetes sp. undet., productoid brachiopods, molds of Spirifer ef. S. centronat"s Winchell, and other brachiopods and indeterminate gastropods.

Helen Duncan made three collections from different parts of the Joana limestone in the Ely district in 1945. She reports that corals are fairly abundant, and she has identified several forms that are characteristic of early Mississippian faunas in the West:

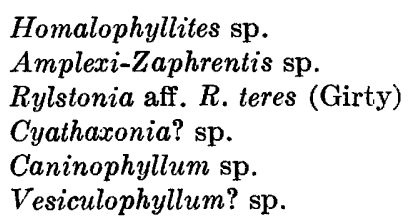

Homalophyllites sp.

Amplexi-Zaphrentis sp.

Rylstonia aff. R. teres (Girty)

Cyathaxonia? sp.

Caninophyllum sp.

Vesiculophyllum? sp. 
Koninckophyllum? sp.

Lithostrotionella? n. sp.

Syringopora aculeata Girty

S. surcularia Girty

Gastropods and brachiopods are associated with the corals in these collections, but most specimens are too poorly preserved for identification.

In addition to its occurrences at Ely and Eureka the Joana limestone has been recognized at a number of other localities in central Nevada and has been especially useful to petroleum geologists in the reconnaissance mapping that has been done during the recent intensified exploration campaign for petroleum. The Joana was considered by this group as a member of the White Pine shale (Easton and others, 1953, fig. 2 and p. 149); we have chosen to continue its earlier use as a formation, in view of its lithologic distinctiveness and the faunal and stratigraphic evidence that it is sharply separable from the adjoining shales. McAllister's (1952, p. 2022) Tin Mountain limestone appears to be a southeastern California equivalent of the Joana.

\section{UPPER MISSISSIPPIAN FORMATIONS}

\section{GENERAL FEATURES}

Sedimentary rocks in the Eureka district, now believed to be of late Mississippian age, present a considerable problem in nomenclature and correlation. Hague (1883, p. 266-268; 1892, p. 68-70) and Walcott (1884, p. 284-285) proposed the names White Pine shale and Diamond Peak quartzite for these beds. The lower formation or White Pine shale was described as being composed dominantly of black shale, with subordinate lenticular sandstones, and to have its type locality in the White Pine (Hamilton) district, about 35 miles southeast of Eureka. The younger unit, the Diamond Peak quartzite, was reported to contain some conglomerate, shale, and limestone in addition to the quartzite that formed the bulk of the formation; its type locality was chosen as Diamond Peak, about 10 miles northeast of Eureka. The two units together were assigned a thickness of 5,000 feet, although Hague emphasized the presence of abrupt lateral and vertical changes in the lithologic character of the White Pine especially.

Hague's two formations have not proven to be satisfactory stratigraphic units. In remapping the area previously studied by him and his associates we have found the two units to be extremely varied in thickness and lithologic character, not only in different thrust plates, but also along the strike within the same plate. In particular we have not been able in many places to select a satisfactory boundary between Hague's White Pine shale and his Diamond Peak quartzite; blackshale layers of considerable thickness and comparable in lithologic character to the bulk of the White Pine persist essentially throughout the interval mapped by Hague as Diamond Peak. Quartzite or conglomerate beds, moreover, that in one place might appear to form a satisfactory boundary between the twc formations lens out within relatively short distances; a similar bed may then appear several hundred fe 3 t higher or lower stratigraphically.

It is probable that this relationship is widespread in the area surrounding Eureka. Althougl the name "White Pine" has been used for black-sbale units in this part of the stratigraphic column as far away as Inyo County in California (Kirk, in Knopf, 1918, p. 38-39) and "Diamond Peak" has been widely applied to clastic beds that overlie black shales, differences in thickness or lithology from the sections in the Eureka district have been so great in many localities where there has been detailed mapping of rocks of this age that local names have been used. Furthermore, in these areas correlations of the units with the sections near Eureka has tended to produce somewhat conflicting age assignments for the "White Pine" and "Diamond Peak." Easton and others (1953, fig. 2) have reviewed some of the current usages for upper Mississippian and lower Pennsylvanian nomenclature and have noted some of the problems presented by the use of the Hague names.

Merriam, in his earlier work on the Devonian (1940, pp. 43-46) and in the Roberts Mountains area (Merriam and Andersoa, 1942, pp. 1690-1691), called attention to these problems; he noted particularly the range in age assignments that have been given to the White Pine shale at the type locality. This formation was originally placed in the Devonian by Hague and $\mathrm{V}^{\top}$ alcott, and collections of both Devonian and Mississippian fossils are known to have been obtained from bets originally assigned to the formation. Merriam, therefore, proposed that the name not be used in the Eureka district, because of the uncertainty regarding its limits and definition, and suggested that "Diamond Peak series" be used for all of the post-Devils Gate Mississippian sedimentary rocks.

An alternative possibility that has been suggested is the use of "White Pine" as a group name to include both the black shales and the coarser clastic bed's of Hague's Diamond Peak quartzite. The use of eitler Diamond Peak or White Pine as a group name, hovever, seems undesirable, in that each has a lithologic connotation that is not appropriate for the upper Mississippian rocks as a whole. We have been reluciant, moreover, to continue the use of "White Pine" as either a group or formation name because of the wide str ttigraphic range of the black-shale sequences to which it has been applied. This is especially true for Eureka, since the recent work has resulted in the removal from Hague's "White Pine" 
shale of the two units which have been described as tormations under the names of Pilot shale and Joana limestone. It has also seemed desirable to reject the usage of Easton and others (1953, p. 149), under which White Pine shale is retained as a formation name, and their proposal that Spencer's (1917, pp. 26-27) Pilot shale, Jonna limestone, and Chainman shale be reduced to member status. This procedure, while it has the advantage of retaining White Pine for the dominant black-shale sequence, does not provide for satisfactory treatment of the thick gradational zone between the black shales and the coarser clastics characteristic of Hague's Diamond Peak.

For the Eureka district we propose to use Diamond Peak formation for the coarse clastic portion of the upper Mississippian sequence where it can be satisfactorily separated trom the underlving black shales, and to adopt Spencer's name of Chainman shale for the lower unit, where it can be separately mapped. For those areas in the Diamond Mountains, where the two are gradational lithologically, we have grouped them in our mapping as "Chainman and Diamond Peak formations undifferentiated." A similar method has been adopted for this report, the descriptive material concerning the undifferentiated areas being included under the present heading, and only the data pertinent to the separately mapped units being presented under the individual formation heading.

The Chainman and Diamond Peak strata vary widely in thickness and detailed lithologic character in each of the major groups of thrust plates in the Eureka district.

In the originally most westerly plate, that above the Roberts Mountains thrust, the two formations are entirely absent, and Permian(?) sedimentary rocks rest directly on the pre-Carboniferous rocks.

The two formations are both present in the exposures of Carboniferous rocks that extend south from Eureka to the mouth of Secret Canyon. Here the Chainman shale and Diamond Peak formation can be distinguished as separate formations and have been mapped as such in Windfall Canyon, on the east slope of Hoosac Mountain, at the mouth of Secret Canyon, and in Dale Canyon. In places in this group of outcrops the Diamond Peak formation is missing, and the Carbon Ridge formation overlies the Chainman shale unconformably. These exposures are described in succeeding sections on the Chainman shale and Diamond Peak formation.

Hague mapped rather extensive areas of "Diamond Peak quartzite" north and south of Devils Gate to the northwest of Eureka. Most of these, however, are actually graptolite-bearing beds of the Vinini formation. We have not as yet completed detailed mapping of this area to determine with assurance if some black shales of the Pilot shale or of the Chainman and Diamond Peak locally overlie the Devils Gate limestone.

The thickest and most extensive exposures of the Chainman and Diamond Peak are found in the $D^{\text {: }}$ amond Mountains, where they form the greater part of the main range for some distance north of Diamond Peak and southwards to Newark Mountain. A narrow band of black shales in Tollhouse Canyon connects the exposures on Diamond Peak with the extensive but discontinuous outcrops north and northeast of Pinto Creek Ranch and in Packer Basin. For almost all of this belt we have been unable to satisfactorily raap the Chainman shale and Diamond Peak formation separately and have therefore shown them as Chainman and Diamond Peak formations undifferentiated. In Tollhouse Canyon, however, there is a considerable exposure of black shale between the Joana linestone and a fault contact with the Pennsylvanian Ely limestone that can be distinguished as Chainman shale. This thickness of shale without interbedded quartzite or conglomerate appears to exceed that found in adjoining sections. Postdepositional thickening may have occurred here as a result of folding or faulting during the course of deformation.

There are two rather different facies represented in the undifferentiated upper Mississippian strata of the Diamond Mountains. The more northerly facies extends northwards from Tollhouse Canyon to beyond the north boundary of the Eureka quadrangle. It contains in its lower half predominant black shales, although above the basal 500 to 600 feet there are abundant sandstone and conglomerate beds. In the upper half the basal part is made up of many thick conglomerate and quartzite beds; this part most nearly resembles the original Diamond Peak quartzite of Hague. This siliceous zone is overlain by more than 2,000 feet of interbedded quartzite; conglomerate; black, greenish, and maroon shales; and rather abundant limestones, many of which are fossiliferous.

In the southern facies, which is extensively exposed in Packer Basin, there is a much smaller thick ress of black shale at the base of the Chainman and Diamond Peak, and yellowish- to reddish-weathering sandstones with subordinate conglomerate and black shale $\varepsilon$,ppearing to predominate throughout the exposure. Here the upper limestone-bearing part of the unit is not erposed.

The black shales found throughout the Diamond Mountains sequence differ perceptibly from the platy and calcareous black shales of the older Pilot shale. They are siliceous rather than calcareous; are black rather than gray on weathered surfaces; and tend, especially in areas of deformation, to yield pencilshaped fragments rather than flakes or plates as in the Pilot. Layers of reddish sandstone one-half inch or 
less thick are interbedded with the shale in most places, and small fragments of the sandstone are characteristic components of the soil that overlies the shale zones.

Near the top of the Chainman and Diamond Peak sequence, there are abundant beds of maroon, greenish, and dark shales. They are found throughout most of the Diamond Mountains outcrop band north of Diamond Peak, and are especially well exposed on the ridge that extends southwest from the summit.

Sandstone, quartzite, and conglomerate are common above the bottom quarter of the Chainman and Diamond Peak. The sandstones are generally gritty and grade upwards into fine conglomerates. In places they yield plant impressions on bedding planes and range from yellowish to reddish brown in color. The sandstones appear to be more abundant towards the bottom and top; near the middle part where coarser clastics make up a large part of the unit they appear to be replaced by grayish-brown vitreous quartzites.

The conglomerate beds are prominent members of the middle and upper parts of the Diamond Mountains section, commonly forming cliffy outcrops that contrast with the smoother slopes underlain by the shale and sandstone members. They range from coarse grits to coarse conglomerates with boulders a foot or so in diameter. The pebbles are in large part of quartzite and chert and may be either rounded or angular. The matrix is also commonly siliceous, although locally a limestone cement may be present.

The chert pebbles are perhaps the most significant and interesting element of the conglomerate beds. Green, gray, black, and white cherts are represented, and all of them can be matched lithologically with bedded cherts in the Vinini formation of the western Ordovician facies. Their presence in the upper Mississippian strata, and not in older formations, indicates that in later Mississippian time the late Paleozoic geanticline in central and western Nevada had risen high enough and rapidly enough to shed coarse debris from the Vinini formation that had by then been exposed.

The lower boundary of the Chainman and Diamond Peak sequence with either the Joana limestone, or with the Pilot shale, is sharp. On the south slope of Diamond Peak, where the Joana is absent, there appears to be an erosional unconformity, but in Tollhouse Canyon farther south the abruptness of the contact may locally be due to shearing. The upper contact, on the other hand, is abruptly gradational, there being 25 to 50 feet of interbedded shales, sandstones, conglomerates, and limestones beneath the massively bedded cherty limestones that are characteristic of the Ely limestone.
Hague $(1892$, p. 69,85$)$ reports a total thickness of 5,000 feet for the combined thickness of the two formations, 2,000 feet being assigned to the White Pine shale and 3,000 feet for the Diamond Peak quartzite. We have measured a maximum thickness of 7,600 feet across the crest of the Diamond Mountains near the northern boundary of the Eureka quadrangle, and nearly this amount is found in the somewhat faulted section that extends from the northwest slope of Newark Mountain to just below the summit of Diamond Peak. Hague (1892, p. 81) measured 1,400 feet of beds in Packer Basin, a figure that accords with our observations; the uppermost beds are here not exposed. South of Eureka the combined thickness of the two formations is much less: in Windfall Canyon only a few hundred feet of black shale is exposed, which is overlain east of Conical Hill by about 200 feet of conglomerate mapped as the Diamond Peak formation. On the west side of the Canyon the conglomerate is absent, and Permian(?) strata rest directly on the black shale. Near the mouth of Secret Canyon and on Carbon Ridge the Diamond Peal formation is 250 to 300 feet thick, and the underlying black shales of the Chainman have an apparent thickness of about 5,000 feet. It is probable, however, that this figure is the result of duplication by folding or faulting, but the exposures are too poor to permit determination of the structure.

\section{AGE AND CORRELATION}

The beds here referred to the upper Mississippian have been assigned in the past to ages ronging from Devonian to Pennsylvanian. We have made scanty collections of marine faunas from the lower black shales and extensive ones in a number of different limestone beds ranging from the middle to the top of the sequence. In addition, poorly preserved plant remairs are found in the sandstone beds throughout the unit, but these do not seem to have age significance.

Our collections, which are discussed in more detail under the Chainman and Diamond Peak headings, are believed to indicate a late Mississippian age for both formations.

This age assignment is in accordancs with the conclusions reached by Weller and hir associates (1948, chart 5) in which Hague's White Pine shale and Diamond Peak quartzite are shown as intergradational and to occupy the time span of the Meramec and Chester.

Easton and his committee of the Eastern Nevada Geological Association (1953, fig. 2), how'ver, regard the Chainman shale as latest Mississippian and the Diamond Peak formation as early Pernsylvanian. 
The early Pennsylvanian age assignment of the Diamond Peak was apparently based on the same fauna that we have found at Eureka and reflects a different interpretation of its time signifieance.

Youngquist (1949) has studied the cephalopods from some black shales in eastern Nevada that he correlates with the White Pine shale. He (1949, p. 283) considered the fauna to be equivalent to European faunas that in turn were correlated with the upper part of the Upper Mississippian. Although this correlation has been questioned by some paleontologists, it might be considered by some as providing grounds for referring the overlying Diamond Peak fauna to the early Pennsylvanian. We do not so consider it. None of Youngquist's collections came from the Eureka district, and the only two cephalopods in our collections were found in the upper part of the Chainman and Diamond Peak sequence. These are of Mississippian age. To judge from Youngquist's descriptions of the local stratigraphy at his collection localities, especially his statement that the fauna occurs in marine limestone lenses from 50 to 200 feet from the top of the black shale, it is conceivable that some of his collections were made from beds that would be equivalent to those near the top of Hague's Diamond Peak quartzite, rather than from the Chainman, or restricted White Pine, shale. This is suggested by the occurrence of black shales near the top of the Chainman and Diamond Peak sequence at Eureka and by the presence of cephalopods in our collections from the higher beds in this sequence.

In view of the considerable variations in thickness and lithologic character of the Chainman and Diamond Peak strata at Eureka it is not surprising that there are relatively few adjoining areas from which a comparable section has been described. Somewhat similar lithologic units are known from the Hamilton district, but Hague (1892, p. 69) reports that the black shale, especially, is appreciably thinner. Sharp (1942, p. 667-670) did not recognize either the Chainman shale or the Diamond Peak formation in the Ruby Range to the north, and recent mapping by James Gilluly (1952, oral communication) and others indicates a similar situation in the Mississippian rocks to the west.

Similar lithologic character, but quite different thicknesses, are reported from localities in the Death Valley region (McAllister, 1952, p. 25-26; Johnson and Hibbard, 1956), but these correlations are somewhat uncertain, and local names for the units have been used.

Correlation of the lower part of the Chainman and Diamond Peak sequence with the Chainman shale in the Ely district to the east (Spencer, 1917, p. 25-27) has been mentioned, although the thickness of the shale is far less than that at Eureka.

It is not improbable that the Upper Mississippian rocks as exposed in the Diamond Mountains are a western clastic equivalent of a nearly equal thi\%kness of dominantly carbonate rocks in western Utah. Faunas from the Woodman formation and the Herat shale member of the Ochre Mountain limestone at Gold Hill, Utah (Nolan, 1935, p. 28, 31) were correlated by G. H. Girty with the "White Pine shale," and a lithologically similar black shale with associated auartzites occurs at the very top of the upper Mississippian section there. Possibly additional detailed mapping in the intervening area between Eureka and western Utah will show intertonguing of the black shales with limestones on the east and sandstones and conglomerates to the west.

Intertonguing of limestone facies of Mississippian age with clastic facies of Chainman and Diamond Peak type is likewise recognized in the Inyo Mountains area of California.

\section{CHAINMAN SHaLE}

The name "Chainman shale" has been used by us for the basal black shale of the upper Mississippian sequence where this unit can be separately mapped. This usage extends the name from its type locelity in the Ely district (Spencer, 1917, p. 26-27), but the position of the unit above the Joana limestone in botl localities seems to warrant the correlation.

We have mapped the Chainman shale separately in only two localities: south of Eureka, a discontinuous band that extends from Windfall Canyon to the mouth of Secret Canyon, and in Tollhouse Canyon east of Newark Mountain. Elsewhere, equivalent bejs are included in the Chainman and Diamond Peak formations undifferentiated.

The formation is generally poorly exposed in the outcrop areas south of Eureka. It is made up almost wholly of black shale, with a few thin interbeds of brown sandstone. The shales appear to be less siliceor's than comparable beds in the Diamond Mountains and in Tollhouse Canyon, though this may be the rerult of less intense deformation; "pencil"-like fragments are less characteristic of the weathered rock, and commonly the presence of the shale can be determined only by the occurrence of small shale particles in the soil. There are better exposures in the wide outcrop at the mouth of Secret Canyon, although they are not good enough to determine the extent to which the section may be repeated by folding or faulting. The apparent thickness of the Chainman here is about 5,000 feet; lut the true thickness is probably much less. The base of the 
formation is not exposed in this western belt, the western limit being marked either by igneous rocks or by a fault contact with the lower Paleozoic rocks.

Hague included this series of outcrops of the Chainman shale in his "Lower Coal Measures" which, for the most part, is equivalent to the Ely limestone of this report. Actually, the Ely is not known to be present in Windfall Canyon, and Permian(?) rocks rest directly on the Chainman shale or on the Diamond Peak formation.

In Tollhouse Canyon, on the other hand, the Chainman is fairly well exposed in many of the small branches at the head of the Canyon. Here too there are relatively few thin sandstone interbeds, but the deformation the shale has undergone has made it difficult to determine either the true thickness of the beds exposed, or the details of its stratigraphy.

Few collections were obtained from the Chainman of the Eureka area. Several consist wholly of plant fragments which, according to Sergius Mamay, of the Geological Survey, do not contribute to an age determination. Five other collections were made from the Chainman by the writers and by G. H. Girty in the vicinity of Conical Hill. The faunules are very similar to the faunules of the overlying Diamond Peak formation. They comprise horn corals, crinoid columnals, brachiopods, poorly preserved pelecypods, gastropods, and trilobite pygidia. Brachiopods are the most abundant, followed by corals. Brachiopods identified include: Rhipidomella nevadensis Meek, Spirifer mortonanus Miller, Brachythyris sp., Dimegelasma cf. D. neglectum (Hall), Linoproductus "ovatus" (Hall), a Dictyoclostus n. sp. also occurring in the Moorefield formation of Oklahoma and in other Mississippian formations, and Chonetes cf. C. oklahomensis Snider. Together these suggest late Mississippian rather than early Mississippian age.

Corals were examined by Miss Helen Duncan (1954, written communication), who reports:

The most conspicuous and abundant corals are small to medium-sized cyathophyllids. A good many of the specimens belong to the genus Faberophyllum, which is common in the Brazer of Idaho and northeastern Utah. I have never seen corals of this type in rocks definitely known to be of Pennsylvanian age.

This collection contains also an assemblage of small horn corals. The forms distinguished in preliminary study include: Heterophyllia sp., Cyathaxonia sp., a carcinophyllid coral with a very prominent axial structure, and several plerophyllids (Ufimia sp., Kindaidia? sp., and Rhopalolasma? sp.). As far as I know, this is the first record of Heterophyllia in North America. This aberrant coral is known from scattered localities in Europe and Asia; Hill reports its range as Visean and Lower Namurian. The carcinophyllids are known mainly from Lower Carboniferous rocks in other parts of the world though the stock persists into later rocks. The only carcinophyllids that
I recall having identified came from the Mississippian of the Osgood Mountains, Nev., and the lower Mississippian dolomite of Utah. Cyathaxonia ranges from Mississippian to Permian. The plerophyllids also range throughout the Carboniferous and Permian and are particularly characteristic of the Permian. We know of several plerophyllids in the Brazer and equivalent formations, but most of the Mississippian forms are not assignable to described genera, which are based largely on Pe"mian material. With the exception of Ufimia, which ranges from Lower Carboniferous to Permian, the plerophyllids in this lot resemble Lower Carboniferous genera more than they do Permian forms.

\section{DIAMOND PEAK FORMATION}

Hague (1883, p. 268-270; 1892, p. 85) characterized the Diamond Peak as a quartzite, but even at this type locality the unit contains a very large proportion of shale, conglomerate, and limestone. Diamond Peak formation therefore seems a more appropriate name.

We have mapped the formation separately only in the region south of Eureka and have elsewhere included equivalent beds in the Chainman and Diamond Peak formations undifferentiated sequence. In the region southwards from Windfall Canyon the formation locally has been completely removed by pre-Permian erosion; elsewhere in this area it ranges up to 420 feet in thickness as in Secret Canyon. Hague included these beds in his "Lower Coal Measures" but, as mentioned above, no outcrops of the Pennsylvanian Ely lirnestone were recognized here.

The Diamond Peak formation in this band of outcrops differs from that in Hague's type area in containing much more calcium carbonate. There is relatively little shale, and both the sandstones and the prominent conglomerate beds have a limestone rather than a siliceous matrix.

The conglomerate beds are the most striking components of the formation south of Eureka. They form cliffy horizons along the east side of Windfall Canyon, along a prominent ridge that extends northwards from Highway 50 at Cherry Spring and for nearly 2 miles north of the lower part of Secret Canyon. The pebbles, as is true elsewhere, are largely of chert derived from the Vinini formation. Most notable, however, is the rapid lateral variation from fossiliferous limestone to conglomerate; in some places one can walk along the strike and pass from a massive limestone to an equal thickness of coarse conglomerate within 50 feet. This phenomenon can be observed both north of Cherry Spring and at the mouth of Secret Canyor.

Fossils are abundant throughout the unit. The fauna is similar to that of the Chainman shale, and is regarded as indicative of an upper Mississippian age.

Collections were made from many zones in the formation. Several contain specimens of such characteristic 
genera of the late Mississippian as Diaphragmus (Productus ss. of authors), and there is little hesitation in assigning them to this age. In most collections, however, definitive index fossils are not present. Especially when a fauna is small, is it difficult to assign it unequivocally to late Mississippian in preference to early Pennsylvanian. Age assignments of such collections either must be left in question or be based on the local general aspects of the faunules. When large and varied faunules contain abundant Rhipidomella nevadensis, big Schizophorias, Spirifers of the Spirifer increbescens type, Orthotetes or closely related forms; linoproductids of the Linoproductus "ovatus" type; Cleiothyridinas, large Compositas, and productids of the Productus inflatus type, it is usually concluded that such assemblages are locally best regarded as Mississippian rather than Pennsylvanian. Conspicuously lacking in collections referred to the Mississippian are Neospirifers, fusulinids, and dictyoclostids of the Dictyoclostus hermosanus type. Likewise absent are definitely Pennsylvanian bryozoans and corals.

An especially varied Diamond Peak fauna occurs in the hundred feet or so of beds that are found on Conical Hill in Windfall Canyon between the Carbon Ridge formation above and the Chainman shale below. Brachiopods are the most important elements in the fauna, but corals and molluscs are present in abundance. Significant brachiopods include Moorfieldella eurekensis (Walcott), Nudirostra carboniferum (Girty), Dimegelasma sp. undet., Syringothyris "carteri" (Hall), and a poorly preserved and tentatively identified Diaphragmus. Gigantoproductus (Productus giganteus of authors) was collected by Girty from these beds and G. A. Cooper (1954, oral communication) has also collected this genus from them.

The molluscan fauna from the beds on Conical Hill that was mentioned by Hague $(1892$, p. 88 ) has not as yet been restudied, but the evidence from the brachiopods and corals indicates clearly a late (post-Osage) Mississippian age.

Two cephalopods were collected from the Diamond Peak formation during the present study and were studied by Mackenzie Gordon, Jr., of the Geological Survey. One of them came from a zone 1,000 to 1,500 feet below the top of the Diamond Peak formation, southeast of the summit of Diamond Peak. Mr. Gordon (1954, written communication) has referred this specimen to "gonatite? indet." Of it he remarks:

Although the specimen is a distorted imprint on shale and no sutures are preserved, some of the surface sculpture can be made out. This pattern and the general evolute shape of the print suggest the British goniatite genus Cravenoceratoides, generally distinguished by its sculpture pattern, and in England and northwest Europe limited to the Eumorphoceras bisulcatum $\left(\mathrm{E}_{2}\right)$ zone. 341051-56-5
I have recognized this genus in Merriam's Inyo Renge area, where it is associated with Eumorphoceras bisulcatum Girty. . . .

The Eumorphoceras bisulcatum $\left(\mathrm{E}_{2}\right)$ zone montioned above is generally considered to be equivalent to strata of Chester age in the United States.

The collection from which this specimen was obtained contains in addition Nudirostra carboniferum (Girty) (Leiorhynchus carboniferum of authors) and Productella cf. $P$. hirsuitiformis Walcott.

The second cephalopod came from a zone close to the top of the Diamond Peak formation in the type area. Mr. Gordon (1954, written communication) referred this cephalopod to Tylonautilus sp. Of it, he reports:

This specimen is referable to a European nautiloid genus, which has not yet been recognized in the literature as occurring in the United States. . . . I regard the genus as limited to rocks of Chester age and have specimens also from the Okaw limestone of Illinois, the Pennington shale of Virginia, the Fayetteville shale and Pitkin formation of Arkansas, the Caney shale of Oklahoma, and the "White Pine shale" of Nevada. The specimen listed by Walcott (1884, p. 281) as Nautilus (like N. digonis Meek and Worthen) belongs in this genus but is apparently \& different species and, as it is associated with Goniatites s.s., pr?bably an earlier species. ... In Europe this genus is reported to be confined to the Eumorphoceras bisulcatum $\left(\mathrm{E}_{2}\right)$ zone.

The occurrence of these cephalopods is of interest, in view of recent descriptions by Youngquist (1949) and Miller, Downs and Youngquist (1949) of a cephalopod fauna from the "White Pine shale." The ag? of this cephalopod fauna is considered by some to b? of late Chester age, whereas Miller, Downs, and Youngquist (1949, p. 610) tentatively consider it to be Meramec.

The local occurrence of some forms that are usually found in Pennsylvanian rocks in association with upper Mississippian ones suggests that there may be $l$ ods that are really early Pennsylvanian in age in the urnermost part of the Diamond Peak formation. We believe, however, that such beds, if actually present, are of small thickness and are confined to the uppermost part of the formation in only a few localities.

\section{PENNSYLVANIAN SYSTEM}

\section{ELY LIMESTONE}

\section{GENERAL FEATURES}

The name "Ely limestone" has been extended to the Eureka district to designate limestones of Pennsylvanian age that occur in the Diamond Mountains as far south as the vicinity of Pinto Creek Ranch. The unit was defined by Spencer $(1917$, p. $27-28)$ in the Ely district and applied to a thick series of massively beddet cherty limestones that appear to be lithologically similar to the beds at Eureka. The age range may not, lowever, be exactly the same as in the Ely area. T.ere the upper part of the Ely as originally described is probably 
of Permian (?) age. Pennebaker (1932) included these beds in his Rib Hill formation.

The strata at Eureka mapped as Ely limestone were included by Hague in his "Lower Coal Measures" (1883, p. $268-270 ; 1892$, p. $85-91)$, and it would seem from his assignment of this unit to a position overlying the "Diamond Peak quartzite" that he intended the "Lower Coal Measures" as a formation name for this Pennsylvanian limestone unit. In his mapping, however, he included beds ranging in age from late Mississippian to Cretaceous in the "Lower Coal Measures," and in the absence of a designated type locality, it is probably idle to speculate on just what beds were intended to be included. The name "Lower Coal Measures," so far as its use as a formation name is concerned, should be abandoned.

Hague's confusion regarding the beds he assigned to the "Lower Coal Measures" stemmed generally from his failure to recognize that two very different facies of rocks were present in two different thrust plates and in particular to the fact that he did not identify two major erosional unconformities. The thicknesses and the lithologic character of the Carboniferous and Permian(?) rocks in the thrust plate containing these rocks south of Eureka are very different from those in the Diamond Mountains. This, combined with the unconformity at the base of the Permian(?) and an even more striking one beneath a thick series of Cretaceous fresh-water sedimentary rocks, led Hague not only into major errors in mapping but to such corollary mistakes as assigning a Cretaceous fresh-water fauna to the "Lower Coal Measures" (1892, p. 87) and a lamellibranch fauna to this unit rather than to the Diamond Peak formation (1892, p. 87-88), and supposing that the "Lower Coal Measures" contained a mixture of lower Carboniferous and Coal Measures faunas (1892, p. 88-91). The evidence for this supposition by Hague was based on fossil collections from Conical Hill, from exposures between there and Eureka, and from Carbon Ridge, which were mixtures of both Diamond Peak and Permian(?) faunas; in all these places, apparently, the unconformity between the two formations was not recognized, and fossils from either side of the unconformity were treated as parts of a single fauna.

We have recognized the Ely limestone only in the Diamond Mountains. To the north, in the Eureka quadrangle, it is found along the east base of the range and in the foothills just west of the State highway in Newark Valley. Southwards the limestone underlies the summit of Diamond Peak and then extends along the west side of Tollhouse Canyon nearly to Pinto Creek Ranch. It is absent not only in the thrust plate of Carboniferous and Permian(?) rocks south of Eureka but also in the Tyrone Gap area where the western sedimentary facies above the Roberts Mountains thrust is exposed.

The formation is uniform in lithologic character, being composed almost wholly of massively bedded bluish-gray limestone. This, in contrast with the somewhat similar limestones near the top of the Diamond Peak formation, commonly contains rodules or bands of black- or tan-weathering chert. Near the base of the limestone there are in places interbedded layers of sandstone and, rarely, of conglomerate, but neither is thick enough or abundant enough to cause outcrops of the Ely limestone to be confused with either the underlying upper Mississippian rocks or the overlying Permian(?) rocks. The sparse chert-pebble conglomerates, however, are of interest because of their evidence that the cherts of the Vinini formation were still supplying debris.

The lower contact with the Diamond Peak is a gradational one. It is well exposed both near the northern boundary of the Eureka quadrang's and on the ridgeline southwest of Diamond Peak, at which locality the following section was observed:

1. Typical cherty massive Ely limestone.

2. Mottled sandy limestone; fossiliferous........... 21

3. Covered.............. 5

4. Calcareous sandstone and quartzite............. $31 / 2$

5. Shale _...

6. Nodular blue-gray limestone with shale partings; fossiliferous........ 6

7. Light-khaki-colored shale

8. Gray-blue limestone; fossiliferous_........... $31 \frac{1}{2}$

9. Khaki-colored shale..... 1

10. Conglomerate.

Total ... $421 \frac{1}{2}$

A similar, but somewhat thicker gradational zone was observed in the saddle about 3,250 feet east of elevation 8,541 on the eastern slope of the Diamond Mountains just south of the north border of the Eureka quadrangle. In the field the contact was placed at the base of unit 2, and this appears to be consistent with the evidence from the fossil collections.

The upper contact of the Ely limestone with the overlying Carbon Ridge formation is an ero ional unconformity. The discordance is well shown both north and south of Newark Summit, southwest of Diamond Peak, where the sandy limestor es of the Carbon Ridge formation in many places transgress the bedding of the Ely limestone and were clearly deposited on a surface of moderate relief.

Hague (1892, p. 86) has reported a thickness of 3,800 feet for the "broadest development" of his "Lower Coal Measures" which suggests that the measurement was made either immediately south of Eureka or in the vicinity of Carbon Ridge. At both localities, however, 
there are probably no strata that we would assign to the Ely, and the quoted thickness is therefore a fictitious one. The Ely sections north and south of Newark Summit do not exhibit the stratigraphic base of the formation, and others farther north in the range that show the base appear generally not to include the contact with the overlying Permian(?) sedimentary rocks. The maximum thickness of the Ely limestone in the Eureka district appears to be about a mile north of Newark Summit, where about 1,500 feet of beds is exposed; the lower contact with the upper Mississippian here is a fault, but it is probable, to judge from exposures not far to the north, that not much of the section is missing. Because of the unconformity below the overlying Permian(?), the thickness varies greatly from place to place; over all of the western part of the Eureka district the formation has been completely removed by pre-Permian(?) erosion.

\section{AGE AND CORRELATION}

The Ely limestone as exposed in this area belongs to the lower half of the Pennsylvanian. Fossils from the lowermost part of the Ely include many forms that have held over from the Mississippian, and it is difficult to determine with certainty whether small collections from the Diamond Peak-Ely transition zone are Mississippian or Pennsylvanian in age. Locally, a few beds of Mississippian age may have been included in the Ely limestone and some of Pennsylvanian in the underlying Diamond Peak beds, for not only are the faunas locally transitional or equivocal, but the lithologic character is also gradational. Fusulinids occur above this lowest part of the Ely and with them come more distinctive, larger fossils.

The lower faunas from the Ely are similar to those which G. H. Girty (1935, written communication) referred to as "pre-Fusulinella bearing beds" and regarded as of Pottsville age. They have also been compared to faunas from the Morrow formation of Arkansas. The faunal resemblance is not very close, however, and the western fauna is best considered as a distinct fauna that is only approximately the equivalent of Pottsville or Morrow age.

Elements of the lower faunas that are considered locally characteristic include the bryozoan genera Rhombotrypella, Ascopora?, and Polypora; large linoproductids; Juresanias; dictyoclostids of the Dictyoclostus coloradoensis, D. hermosanus, or D. portlockianus type; and certain Marginiferas. One or more of these elements, when coupled with a scarcity of large Rhipidomellas, Schizophorias and Cleothyridinas, have formed the basis for a tentative local reference to the Pennsylvanian. It was to be expected that these beds would contain the long-ranging fusulinid Millerella, but it was not found during the course of our investigations.
The higher faunas in the Ely limestone are characterized by fusulinids. They have been referred to an Atoka age by L. G. Henbest, who studied all of the fusulinids collected. Mr. Henbest (1951, written communication), reported:

The species of Fusulinella in the first sample examined (F-9005-b) has unusually thick primary walls and aroused suspicion that it might represent a higher horizon than similar species do in the United States. Hastily made sections however, revealed the presence of Climacammina sp., Bradyina sp., Millerella sp., Millerella pingus Thompson, Pseudostaffelia and Fusulinella sp. in this and in F-9015. This assemblage characterizes rocks of about middle Atoka age .... The fauna here correlates approximately with that in limestone lenses in a fanglomerate half a mile S. $35^{\circ}$ E. of Antler Peak, Nev., where Fusulinella is associated with Chaetetes sp.

The larger fossils in this part of the Ely are less common and less varied than they are in the pre-Atoka beds. Chaetetes of the $C$. milleporaceus type occurs in collections of Atoka age. Although known elsewhere in rocks that are probably of Mississippian age, this coral is as yet known locally only in rocks of Atoka or of Des Moines ages.

No fusulinids or larger invertebrate fossils characteristic of a Pennsylvanian faunal zone younger than the Atoka have as yet been found in the Ely limestone of the Eureka district. There appear to be no beds definitely of late Pennsylvanian age in the area; if any were originally present they presumably were removed by pre-Carbon Ridge erosion.

Correlatives of the Ely limestone appear to lie to the east and southeast. In addition to the limeston es of the type locality at Ely the formation is thought to be nearly contemporaneous with the limestones of the lower 3,000 feet of the western facies of the Oquirrh formation at Gold Hill, Utah (Nolan, 1935, p. 34-35). Similar limestones also are probably present at Pioche, Nev. (Westgate and Knopf, 1932, p. 21-23), Muddy Mountains, Nev. (Longwell, 1928, p. 31-32), and the Spring Mountains, Nev. (Hewett, 1931, p. 21-30; Iongwell and Dunbar, 1936, p. 1204).

In the western part of the Eureka district, the unit is absent. Still farther west, in areas recently studied by Ferguson, Muller, Roberts, and Gilluly, fusulinid faunas comparable to those of the Ely limestone have been collected from coarse clastics that are lithologically quite dissimilar.

\section{LATE PALEOZOIC (PERMIAN?) ROCKS}

Upper Paleozoic rocks of Wolfcamp and later age are widespread in the Eureka district, where they exhibit great lateral variation. In these strata three facies have been recognized, each being characteristic of different thrust blocks. Two of these, found to the south and to the east of Eureka, respectively, are dominantly carbonate-rich and, although they differ 
in lithologic detail, are sufficiently similar to be included under a single formation name, the Carbon Ridge formation. This formation probably represents a large part of Wolfcamp time (Permian(?) of the U. S. Geological Survey) and likewise embraces post-Wolfcamp strata of probable Leonard (Permian) age. In the Diamond Mountains an eastern facies of the Carbon Ridge rests unconformably upon the lower Pennsylvanian Ely limestone; a western facies of this formation at the type locality of Carbon Ridge lies with even more marked unconformity upon upper Mississippian Diamond Peak strata.

The most westerly facies of the Wolfcamp and younger strata differs lithologically from the two facies of the Carbon Ridge formation, being composed very largely of clastic rocks. This western formation has been designated as the Garden Valley formation; it rests with pronounced angular unconformity on the Ordovician Vinini formation.

The lithologic variations from east to west in the three facies and their unconformable relationships to underlying strata appear best explained by postulating a rising land mass in central Nevada during Carboniferous and subsequent late Paleozoic time. Stratigraphic evidence from the Eureka district would suggest that this land mass or geanticline may have had greater relief and have arisen more spasmodically than was originally thought (Nolan, 1928).

\section{CARBON RIDGE FORMATION GENERAL FEATURES}

The name Carbon Ridge formation is here proposed for the rocks of Permian(?) age that are found south and east of Eureka. As is true of the other post-Devonian sedimentary rocks, Hague's original nomenclature has proven inadequate or even erroneous, and a new name appears to be the only means of clarifying the relationships that are now recognized. It seems probable that Hague (1883, p. $270 ; 1892$, p. 93-95) intended that his "Upper Coal Measures" formation include the beds here assigned to the Carbon Ridge formation. But the sediments he mapped as "Upper Coal Measures", in addition to including some beds belonging to the Carbon Ridge, include cemented late Tertiary or early Quarternary limestone fanglomerates, some Recent fanglomerates, and locally Cretaceous sedimentary rocks, whereas in many places, and especially over much of the area south of Eureka, rocks mapped by Hague as "Lower Coal Measures" are actually in large part now considered to be a part of the Carbon Ridge formation. The name, Arcturus limestone, which was defined by Spencer at Ely $(1917$, p. 28) also seems inappropriate. This formation was originally assigned by Spencer to the Pennsylvanian, and was correlated, on the basis of its fauna, with the Kaibab limestone, which is now generally beliered to be of Permian age; to judge from the fauna, it is probable that the Arcturus may be younger than the Carbon Ridge formation.

Two facies of the Carbon Ridge hare been distinguished: an eastern facies, which occurs in the Diamond Mountains; and a western one, which is found south of Eureka.

One of the best exposures of the western facies of the Carbon Ridge formation is on the topogr? $p$ hic feature of that name lying just north of the mouth of Secret Canyon; it is designated as the type are". Here the formation overlies the Diamond Peak fcrmation and is itself overlain by the Cretaceous Nevrark Canyon formation. Carbon Ridge is at the south end of the series of discontinuous exposures that constitute the western facies. Other exposures in the bolt are found on the eastern slope of Hoosac Mountain, on Spring Ridge and Gorman Hill, and on the southwestern slope of Richmond Mountain.

The eastern facies of the Carbon Ridge is continuously exposed along the western slope of the southern portion of the Diamond Mountains. It overlies the Ely limestone in this region and is itself overlain unconformably by the Newark Canyon formation, which completely overlaps it a short distance south of the Newark Canyon road.

The Carbon Ridge formation is characteristically thin bedded and heterogeneous in lithologic character, although calcareous rocks predominate; it generally forms smooth rounded slopes. Both freies contain abundant thin-bedded sandy limestone, wl ich weathers to shades of brown. The eastern, or Diamond Mountains, facies also contains many beds of brown, yellowish and purplish sandstone, especially neer the base. Similar sandstones are present south of Eureka, but are not as abundant; carbonaceous sandstones and dark-gray carbonaceous sandy shales, containing in many places oval concretions as much as a foot in diameter, appear to occupy the same stratigraphic position as the sandstones to the east. Thicker limestone beds are common only south of Eureka; here many are coarsely crystalline, gray in color, and cherty. Both black and brown chert lenses and stringers occur and are found not only in these massive limestones, but also in the thinner bedded sandy limestones to the east. Chert-pebble conglomerates are fairly common in both facies, but the Vinini-type chert fragments are small and the rocks normally resemble limestones more than conglomerates. At the top of the Carbon Ridge formation north of the Newark Canyon road, however, there are abundant coarse conglomerates. These, unlike the conglomerates in the $\mathrm{D}$ amond Peak 
and Newark Canyon formations, are made up chiefly of limestone pebbles and have a calcareous cement. We have not recognized any of the thick zones of evaporites that were found in the Summit Springs well, some miles east of Eureka.

Both the upper and lower contacts of the Carbon Ridge formation are erosional unconformities. In the Diamond Mountains the formation rests on the Ely limestone, locally with a marked angular discordance, beds of the older limestone striking into the contact and being terminated by it. South of Eureka the Carbon Ridge formation in most places is fairly accordant in strike and dip with the Diamond Peak formation, which here underlies it; locally, however, the Diamond Peak is absent, and the Carbon Ridge rests directly on the Chainman shale. In this region all the Ely either has been eroded or was never deposited.

Both facies of the Carbon Ridge are unconformably overlain by the Newark Canyon formation. South of the Newark Canyon road, the Cretaceous strata transgress the eastern facies of the Carbon Ridge so acutely that the entire thickness of the Carbon Ridge disappears beneath the Newark Canyon formation $1 \frac{1}{2}$ miles south of the road. At the south end of the exposure of the western facies, near the mouth of Secret Canyon, a belt of conglomerate which is probably a part of the Newark Canyon overlies the Carbon Ridge with apparent conformity. As the zone is followed northwards toward Eureka, however, angular discordance between the two is clearly apparent. The Cretaceous strata overlap the fault contact between the Carbon Ridge and older Paleozoic rocks throughout the lower part of New York Canyon; the transgressive nature of the contact is also well shown along the northeast and northwest slopes of Gorman Hill and in the vicinity of Cherry Spring where grits and limestones of the Newark Canyon strike and dip with notable discordance to the Carbon Ridge rocks beneath.

Hague (1892, p. 93) estimated the "Upper Coal Measures" at Eureka to be about 500 feet thick, but as we have mapped the Carbon Ridge formation, there appears to be a maximum of at least 1,500 feet of beds exposed north of the Newark Canyon road and 1,750 feet on Carbon Ridge. These figures are very much less than the thickness of beds referred to the Permian that were cut by the Summit Springs well of the Continental Oil Co. and Standard Oil Co. of California about 50 miles to the east, but because of the unconformity at the top of the formation, there is no basis for judging whether or not this difference is an original one.

\section{AGE AND CORRELATION}

The Carbon Ridge formation has a fairly abundant fauna which indicates that the bulk of the formation is of Hueco (Wolfcamp) age, and thus the main part of the Carbon Ridge is assignable to that controversial zone between undoubted Carboniferous and undoubted Permian. Solution of this problem seems more to require a general agreement on the appropriate porition of the systematic boundary rather than additional local faunal or stratigraphic evidence, and the Cr.rbon Ridge formation is here given the current age assignment of the Geological Survey for the Hueco (Wolfcamp), which is Permian(?).

Some of our fossil collections include forms that suggest a late Pennsylvanian age for the lower part of the formation; others from beds near the top are suggestive of a post-Wolfcamp age. The fossils suggestive of Pennsylvanian age are, however, associated locally with ones indicative of the Permian(?), ard an older age for the lower part of the formation s?ems somewhat unlikely. The evidence for a post-Wolfcrmp, or Leonard, age for the uppermost beds is better and the Carbon Ridge formation probably ranges in age from Wolfcamp up into Leonard time.

The faunas of the Carbon Ridge as represented in the collections from the Eureka district contain fusulinids, corals, crinoid columnals, echinoid sfines, bryozoans, pelecypods, cephalopods, and trilobites

Fusulinids are perhaps the most abundant element in the Carbon Ridge faunas. A number of collections from both facies of the Carbon Ridge have been studied by L. G. Henbest, of the Geological Survey. He (1951, written communication) has distinguished four faunal zones.

Henbest's first zone is characterized by cylinc'rical species of Triticites. Of this zone he writes:

Cigar-shaped species of Triticites such as T. irregularis (itaff), T. ohioensis, T. oryziformis Newell, T. plicatulus Merchant and Keroher are prolific, widely distributed, and so far as definitely known are restricted to the middle and upper parts of the Missourian epoch of the later Pennsylvanian. In the Eureka collections, species of Triticites that resemble T. plicatulus Mershant and Keroher from the Plattsburg limestone of Kansas are found, but some of the specimens show a more advanced evolution and approach to the morphology of Schwagerina, a Permian fo-m.

Though such faunas as these seem to indicate Missour: age, a new genus recently found in a collection from the Hueco limestone of the Sierra Diablo, Texas, suggests the possibility (1) that in some part of the world so far unknown the cylindrical forms may have survived the Missourian or (2) that the Texas species represents a new or unrelated generic stock. It will require considerable preparatory work on the collections here and a study of the field evidence to decide this question.

We have made collections of this fauna during the present investigation only from the exposures south of 
Eureka; all but one of these appear to have come from low in the Carbon Ridge formation. One collection from Spring Ridge on the east side of Windfall Canyon, however, appears to lie above collections containing faunas characteristic of the higher faunal zones. Brachiopod faunas associated with some of these collections are, moreover, suggestive of Hueco age, and it is therefore more likely that this first or lowest zone is of Wolfcamp, or Hueco, age.

Henbest's second and third zones are characterized by Pseudoschwagerina and Schwagerina, respectively. Collections containing faunas characteristic of the two zones were made from both the eastern and western facies of the Carbon Ridge formation, although the Pseudoschwagerina fauna is more abundant in the western facies and the Schwagerina fauna in the eastern facies. In both, there appears to be some suggestion that the two faunas interfinger. Of the Pseudoschwagerina fauna, Henbest (1951, written communication) reports:

Though the search was not exhaustive in the material supplied, Schwagerina sp., Schubertella? sp. and Schwagerina? aff. $S$. compacta (White) were commonly found in association with the species of Pseudoschwagerina. In the more complete successions of Kansas, central Texas, and New Mexico this fauna appears somewhat above the base of the Hueco limestone and is restricted to that epoch.

In the third zone, he (1951, written communication) found:

foraminiferal faunas characterized by Schwagerina, in some instances accompanied by Schubertella and in many instances by Schwagerina? of the $S$. compacta (White) group.

The highest or Parafusulina zone was found only north of the Newark Canyon road in the Diamond Mountains. Henbest examined a collection made about a mile northwest of Newark Summit and made the following report:

Spandelina ? sp.

Endothyranella sp.

Schubertella? sp.

Schwagerina sp.

Schwagerina guembeli ? Dunbar and Skinner.

Schwagerina (or Parafusulina ?) franklinensis Dunbar and Skinner.

? Schwagerina huecoensis Dunbar and Skinner.

Parafusulina sp.

The fusulinids in this sample seem to represent one of the higher Permian faunas so far seen from your area. I doubt that it is older than upper Hueco. It seems to be as young as Leonard and possibly as young as the lower part of the Nosoni formation.

Larger invertebrate fossils from the Carbon Ridge formation were studied as long ago as 1928 by G. H. Girty, who correlated the fauna with that of the Hueco limestone. This fauna has not, however, been thoroughly collected or thoroughly studied. Most of the larger invertebrates so far obtained are poorly preserved, and many of them are fragmentary. Sig- nificant elements prominent in it include: "Buxtomia" cf. B. peruviana (d'Orbigny); Dictyoclostus huecoensis King; D. ivesi? (Newberry); D. sp. undet., aff. $D$. (Antiquitonia) multistriatus (Meek); a large Linoproductus that is undescribed but also occurs in the Hueco limestone; Linoproductus sp. undet. aff. L. (Cancrinella) phosphaticus (Girty); Leiorhynchoidea? cf. L. schucherti Cloud; Spirifer cf. S. marcoui infraplicatus King; and Hustedia meekana (Shumard). Other noteworthy brachiopods present belong to Meekella, Chonetina, Juresania, Wellerella, Spirifer, Neospirifer, Composita, and Punctospirifer. Corals and bryozonns identified by Helen Duncan include the colonial coral, Protowentzelella, hitherto reported from the Permian of Russia, coarsely fenestrate species of the bryozoans Polypora and Septopora and several ramose genera including Rhombotrypella and Rhabdomeson. No cэphalopods of restricted stratigraphic range were found in the Carbon Ridge formation. The brachiopod element of the fauna resembles that of the Hueco fauna, but it includes some forms suggestive of Permian species that occur in rocks younger than the Hueco.

The fauna of the Rib Hill formation cf Pennebaker appears to correlate with the Carbon Ridge; otherwise there are no published descriptions of Permian formations in areas adjacent to the Eureks district that appear to be similar to, and correlative with, the Carbon Ridge formation. Westward, even in the Permian section at Tyrone Gap west of north from Eureka, the Permian rocks are dominantly clastic and lithologically quite distinct. To the southeast and northeast the Permian sections are usually correlated with the Plateau section (Supai formation, Coconino sandstone, Kaibab limestone), and with the Park City and Phosphoria formations, respectively. Sharp (1942) reported no Permian in the Ruby Range immediately northeast of Eureka, and Spencer's (1917, p. 28) Arcturus limestone in the Ely district sppears to be dissimilar lithologically and faunally. Rok ort's ${ }^{12}$ Antler Peak formation, found near Golconda, Nev., and Gilluly's (1932, p. 34-38) Oquirrh formation are also dissimilar, but may be in part of the same general age.

The Eureka district thus lies where three quite different late Paleozoic sections approach one another, and it is unfortunate that the exposures of the Carbon Ridge formation do not encompass a greater time span in the Permian(?) and Permian, so that the relationships between the three might be clarified. Recent work by petroleum geologists of several oil companies, who have been working east of Eureka. have shown that between Eureka and Ely there are very consider-

\footnotetext{
12 Roberts, R. J., 1949, Geology of the Antler Peak quadrangle, Nevada; U. S
} Geol. Survey open-file report. 
able thicknesses of Permian rocks that may provide this information.

\section{GARDEN VALLEY FORMATION}

GENERAL FEATURES

The Permian(?) rocks associated with the Ordovician Vinini formation in the Roberts Mountains thrust plate are here described as the Garden Valley formation, from their occurrence along the east side of Garden Valley on the western slope of the Sulphur Spring Range. These sediments were first studied by Merriam and Anderson (1942, p. 1691-1692) during their reconnaissance of the Roberts Mountains and have subsequently been mapped of us. We regard the Garden Valley as of at least formational rank; in the future it may conceivably be elevated to group status, since there are four lithologically distinctive members in the area mapped and at least one erosional discontinuity.

The Garden Vallev formation extends from about a mile south of the south boundary of the Garden Valley quadrangle to the north boundary of that sheet. The best exposures are immediately north and south of Tyrone Gap, at the southeast corner of the quadrangle. We have not recognized the formation farther east, and it is probably absent in the Antelope Valley region. The formation is topographically quite distinctive, forming a prominent and essentially continuous ridge throughout the region of its exposure.

The four members that constitute the Garden Valley formation are: (1) a basal limestone member; (2) one made up of conglomerate, sandstone, and shale; (3) a resistant siliceous conglomerate; and (4) a sequence of purple and red shales and conglomerates.

The basal limestone member is 450 to 500 feet thick. Much of it is made up of thin-bedded sandy limestones and limy sandstones which weather brownish. These beds are normally poorly exposed and in most places form a saddle between the more thickly bedded limestones that are found at the bottom and top of the member. The lower thick-bedded limestone is as much as 40 feet thick, but locally it is missing, and thinbedded sandy limestones rest directly on the Vinini formation; in one place a chert-pebble conglomerate with cobbles as much as 6 inches in diameter occurs at the contact. The massive limestone at the top of the unit is even more local in occurrence. It is cherty, with abundant nodules and stringers of tan chert. Especially to the south the top of the member is marked by a coarse conglomerate with limestone pebbles and boulders and a limy matrix.

The limestone member is overlain disconformably by a heterogeneous member that is made up of siliceous conglomerate at the base, sandy shales in the middle, and sandstone at the top. It ranges in thickness from
800 to 1,000 feet and, like the basal limestone mem ber, is characterized by a saddle in the center of the unit, resulting from the easy erosibility of the shale. The conglomerate at the bottom of the member is coarse and siliceous, with boulders of chert and quartzite in a quartzose matrix. Locally the basal bed of the conglomerate is a cobble conglomerate, with individual rounded cobbles as much as 4 inches in diameter. This rests on the underlying limestone member with marked discordance. Bedding in the limestones and limestone conglomerates below is sharply transgressed, and erosional channels, filled with siliceous conglomerate cut into the lower beds as much as 20 feet. The central shale unit is poorly exposed; it is highly carbonaceous and contains fish plates and plant remains in places. The upper sandstone is also carbonaceous and breaks down on weathering to thin plates or slabs that are tan or brownish.

The contact of the third, or siliceous conglomerate, member with the underlying sandstones is a conformable one. This member is the most resistant to erorion of the four, and the prominent ridge that extends for nearly the whole length of the Garden Velley quadrangle is underlain by it. The conglomerntes with some interbedded arkosic sandstones or quartzites are 900 to 1,000 feet thick, and individual conglomerate beds may be 5 to 10 feet in thickness. The pebbles and cementing matrix are both silicesus, the cobbles being of quartzite and chert. The prevailing color of the member is dark reddish brcwn.

The upper "red beds" member, attaining a thickness of at least 550 feet, is relatively weak and porrly exposed as a general rule. It is composed of purplish, reddish, and chocolate-colored conglomerates, shales, and sandstones. The conglomerates, unlike the underlying ones, are not siliceous but are composed of limestone pebbles and cobbles, set in a silty, deeply colored matrix. The contact with the siliceous conglomerate appears to be gradational, as the narrow contact zone shows interbedding of the two types of conglomerate.

The contact of the Garden Valley formation with the underlying Vinini formation was originally marned by Merriam and Anderson (1942, p. 1691) as a fault contact. Excellent exposures south of Tyrone Gap, however, show that the contact at this place is unconformable and that there is an angular discordence between the two formations. Detailed mapping shows that individual beds of chert, shale, or limestone in the Vinini are truncated by the contact, and in a number of places, angular fragments of the underlying chert are enclosed in limestone of the overlying Permian(?) strata. The mapping also shows that the Vinini formation had undergone at least minor folding in 
pre-Permian time, and there is some evidence that it had also been affected by minor thrust faulting. Indirect evidence, however, suggests that the major movement along the Roberts Mountains thrust, was of post-Permian age. The notable difference between the section at Tyrone Gap and the late Paleozoic sections, a short distance to the east and south in the Diamond Mountains and south of Eureka, seems to require that a thrust of the magnitude of the Roberts Mountains fault must separate them.

\section{AGE AND CORRELATION}

The Permian (?) age of the Garden Valley formation is based on fossil faunas found in the basal limestone member; the upper part of the formation may be younger, so far as the evidence provided by the indeterminate fossils found in the upper three members is concerned. This is especially true of the top or "red beds" member, as the poorly preserved pelecypods found in it might equally well be interpreted as Mesozoic rather than Permian species. Until diagnostic fossil evidence is found, however, the conglomeratic zones in all four members have been taken as the basis for placing all four members in a single formation of Permian (?) age.

The faunas in the basal limestone member are found at two horizons: one in the lower thick-bedded limestone at the base of the unit, the other about 100 feet below the top. The lower-limestone fauna includes an assemblage of small brachiopods and locally abundant fusulinids; the fusulinids, however, appear to be limited to the uppermost part of this zone. The upper fauna contains mainly fusulinids. Both faunas probably are, on the basis of the fusulinids, of rather late Hueco or Wolfcamp age, though there is some indication from the fusulinids and brachiopods that rocks of Leonard or even younger Permian age are present.

The lower of the two faunas contains abundant Schwagerina sp. and large numbers of a brachiopod identified as Leiorhynchoidea n. sp. aff. L. schucherti Cloud. Also present are the following additional brachiopods: Chonetina sp. undet., "Avonia"? cf. A. subhorrida (Meek), Composita sp. undet., and Hustedia sp. undet. Many of the specimens are so beekitized that structures essential to correct identification cannot be observed.

The upper fauna yields Pseudoschwagerina sp., and in addition, according to L. G. Henbest (1953, written communication):

"Triticites" sp.

Parafusulina sp. (intermediate between Schwagerina linearis

Dunbar and Skinner of late Hueco age and Parafusulina

lineata $\mathrm{D}$. and $\mathrm{S}$. of Delaware Mountain age, West Texas
Permian. This form has more axial filling than $P$. nosonensis Thompson of the Nosoni formation, California.) Late Hueco or more likely Leonard age is indicated.

Parafusulina is the predominating genus in the upper fauna, with the Pseudoschwagerina restricted to local pockets in the fusulinid limestone.

The Garden Valley formation, like the Vinini formation, represents a more westerly facies than the other sedimentary rocks exposed in the Eureke, district. Its correlatives thus are found to the west $c^{f}$ Eureka, and there appear to be no sections to the east which it resembles lithologically or, to any extent, faunally. To the west, the Garden Valley would appear to correlate with at least parts of the Havallal formation of the Mt. Tobin and Antler Peak quadrangles (Muller, Ferguson, and Roberts, 1951; Roberts, 1951). It may also be equivalent to the McCloud limestone of northern California.

\section{CRETACEOUS SYSTEM}

\section{NEWARK CANYON FORMATION}

\section{GENERAL FEATURES}

The widespread occurrence of freshwater Cretaceous sedimentary rocks in the Eureka district was not recognized by Hague and Walcott. To this is due many of the errors made by them in descriling the postDevonian stratigraphic section, as well as in their interpretation of the structural and stratigraphic history.

Presence of these rocks at Eureka was first suspected by W. P. Woodring, of the Geological Survey. He considered that the gastropods that were believed by Hague $(1892$, p. 87$)$ and Walcott $(1884$, p. 8) to come from a nonmarine part of the "Lower Coal Measures" were in fact closely related to Cretaceous species with which he was familiar. At his suggestion, early in our detailed mapping at Eureka in 1938, collections were made from some of Walcott's original localities. These were examined by F. S. MacNeil, who assigned them to the Lower Cretaceous (1939).

Subsequent mapping has shown that beds of this age are extensively developed south and east of Eureka. For them we propose the name of Newark Canyon formation, as the best exposures of the strata are in Newark Canyon, where they extend from above Hunter's Ranch to Newark Summit on the west side of the Diamond Mountains. The Newark Canyon formation includes almost all the strata mapped by Hague as Weber conglomerate (1883, p. 270; 18@2, p. 91-92), although in a few places the Weber as mapped included beds we have assigned to the Diamond Peak formation, the Ely limestone, and the Carbon Ridge formation. 
In addition, some of the rocks that Hague included both in his "Lower Coal Measures" and "Upper Coal Measures" have now been mapped as part of the Newark Canyon formation. The most notable of these occurrences is just south of Eureka, where beds described by Hague as of fresh-water origin in "Lower Coal Measures" time, are now generally believed to be a part of the Cretaceous section and to lie unconformably on the Carbon Ridge formation.

The Newark Canyon formation occurs in two main bands of outcrop in the vicinity of Eureka. The more westerly extends from Eureka south to the mouth of Secret Canyon, between Hamburg Ridge on the west and Richmond Mountain and the adjoining mountainous area underlain by Devonian sedimentary rocks on the east. The exposures of Cretaceous rocks in this band are mostly discontinuous and of small extent; there is, however, a continuous band of conglomerate that we believe to be a part of the formation extending for about 2 miles southward from Pinto Basin. The formation commonly rests unconformably on Carbon Ridge strata, but locally it overlies Paleozoic rocks as old as the Pogonip group. The more easterly band lies west of Tollhouse Canyon and extends from the vicinity of Pinto Creek Ranch northwards nearly to Black Point on the west flank of the Diamond Mountains. In contrast with the westerly band the Cretaceous strata here form a fairly continuous exposure. It is probably that the two bands were once part of a single occurrence; they have been separated by postCretaceous faulting and erosion and by later extrusions of lava.

A small isolated exposure of probable Newark Canyon age lies on Devonian Devils Gate limestone at the edge of Antelope Valley 12 miles west of Eureka.

Lithologically the Newark Canyon formation is heterogeneous to an extreme. It is made up of freshwater limestones, conglomerates that contain both siliceous and limestone boulders, silts, sandstones, and grits. Over most of its outcrop area it is poorly exposed, the surface being underlain by a deep soil apparently derived from silty beds in the formation. The soil, which in many places is deep red in color, is one of the most characteristic features of the formation. Another is the widespread occurrence of fresh-water limestones. There are dense porcellaneous rocks, with a high content of silt and locally of organic matter, that weather to a light blue gray in most places, although locally brownish tints prevail. In places they contain small angular fragments of chert similar to chert in the Vinini formation and grade into chertpebble conglomerates. In several places, notably about 1,550 feet east of elevation 7875 on the Newark Canyon road, the limestones occur at the base of the formation and are conglomeratic, with fragments of the uncerlying rocks as much as several inches in diameter.

The silts, sandstones, and grits probably form the greater part of the sequence, but they are generally poorly exposed except where nearby volcanic sctivity has resulted in local induration. All three are normally dark in color, owing to abundant carbonaceous material, but locally the silts are pinkish or brown and contain appreciable amounts of sand. Good exposures of such beds are found on the steep slopes of the hills 4,690 feet and 2,400 feet north of west of Fusulina Perk just south of the Newark Canyon road. Grits are Fossibly somewhat more abundant in the more westerly band of exposures. They may be examined to advantage in the two tunnels on the north slope of Gorman Hill, south of Eureka and northwest of Cherry Spring.

Conglomerates are perhaps the most striking components of the formation. The steeply dippinz thick belt of conglomerate that extends from Pinto Basin to the mouth of Secret Canyon is readily apparent from Highway 50 near South Gate. Elsewhere scith of Eureka the conglomerate beds are usually poorly exposed, even though they are well indurated; in places it is difficult to distinguish these Cretaceous strata from the cemented gravels that are found along many of the old drainage channels. The siliceous conglomerates in the eastern band of outcrops, on the other hand, are well exposed in many places, but they resemble so closely the conglomerates of the Diamond Peak formation that they are easily confused with those older rocks.

The Newark Canyon formation rests unconformably on the underlying rocks. The unconformity is angular in most places, and the basal beds of the formation transgress boundaries between the Paleozoic formations and rest upon most of the earlier formations from the Pogonip group up to the Carbon Ridge formation. South of Pinto Basin, however, conglomerates believed to be at the base of the Newark Canyon formation, are approximately conformable with the Carbon Ridge, but this relationship appears to be local in extent. Excellent exposures of angular unconformity may be observed at several localities along the Newark Canyon road. The one east of elevation 7875 has been mentioned. Others may be seen a quarter mile southwest of hill 8202 west of Tollhouse Canyon, and soutr. of the hill 2,400 feet west of north of Fusulina Peak in the same region. At the locality near hill 8202 the Newark Canyon strata rest on Ely limestone; at the locality north of Fusulina Peak, on Carbon Ridge formation. Another good exposure of the unconformity is shown east of Cherry Spring south of Eureka, where the Cretaceous rocks rest with marked discordance on 
nearly vertical conglomerate beds of the Diamond Peak formation.

The formation is overlain unconformably by Tertiary(?) and Quaternary sediments and by volcanic rocks. On the north and west sides of hill 7875, north of the Newark Canyon road, the disappearance of the formation beneath the cemented limestone fanglomerates that lie on the west flank of Diamond Peak is well shown.

Hague (1892, p. 92) suggested a maximum thickness of 2,000 feet for the Weber conglomerate as described by him, and this figure corresponds rather closely with a rough measurement of 1,800 feet made on the exposures along Newark Canyon. A much smaller thickness appears to be present in the band of outcrops south of Eureka, although there are 1,400 feet of conglomerate exposed just west of South Gate and south of Pinto Basin.

\section{AGE AND CORRELATION}

The fossils described by MacNeil (1939, p. 355-360) provide the best evidence for the Lower Cretaceous age of the Newark Canyon formation. He notes (p. 355):

By comparison with other known fresh-water faunas, the fauna of the new formation is of Cretaceous age, and on the basis of closely related species of unionids and of a new Musculium-like genus would appear to be of the approximate age of the lower Blairmore formation of southwestern Alberta, which is assigned to the Lower Cretaceous. Dr. Ronald W. Brown, of the Geological Survey, has examined plants from Eureka and reports that they, too, indicate a Lower Cretaceous age for the beds in question.

We have subsequently found, in addition to the gastropod fauna, plant and fish remains. Localities on either side of the Newark Canyon road at which these occur were first reported in 1939 by Sheridan Berthiaume (oral communication), then of Cornell University. The fossil fish which occur about 3,250 feet southwest of elevation 7875 on the Newark Canyon road have been described by David (1941); she regarded them as indicating an early Cretaceous age for the enclosing beds, thus confirming the earlier determination by MacNeil.

\section{REFERENCES CITED}

Baldwin, E. M., 1943, Three Forks fauna in the Lost River Range, Idaho: Am. Paleontology Bull., v. 28, no. 110, p. 3-18.

Ball, S. H., 1907, A geologic reconnaissance in southwestern Nevada and eastern California: U. S. Geol. Survey Bull. 308.

Berry, G. W., 1943, Stratigraphy and structure at Three Forks, Mont.: Geol. Soc. America Bull., v. 54, p. 1-30.

Burling, L. D., 1914, Early Cambrian stratigraphy in the North American Cordillera (with discussion of Albertella and related faunas): Canadian Geol. Survey Mus. Bull. 2,. p 93-129.

Cooper, G. A., and others, 1942, Correlation of the Devonian sedimentary formations of North America: Geol. Soc. America Bull., v. 53., p. 1729-1794.
Curtis, J. S., 1884, Silver-lead deposits of Eurela, Nev.: U. S. Geol. Survey Mon. 7.

David, Lore, 1941, Leptolepsis nevadensis, a new Cretaceous fish: Jour. Paleontology, v. 15, p. 318-321.

Deiss, C. F., 1938, Cambrian formations and sections in part of Cordilleran trough: Geol. Soc. America Bull., v. 49, p. 10671168.

Easton, W. H., and others, 1953, Revision of strntigraphic units in Great Basin: Am. Assoc. Petroleum Geologists Bull., v. 37, p. 143-151.

Ferguson, H. G., 1924, Geology and ore deposits of the Manhattan district, Nevada: U. S. Geol. Survey Bull. 723.

Ferguson, H. G., Roberts, R. J., and Muller, S. W., 1952, Geology of the Golconda quadrangle, Nevada: U. S. Geol. Survey Geologic Quadrangle Map GQ-15.

Gilluly, James, 1932, Geology and ore deposits of the Stockton and Fairfield quadrangles, Utah: U. S. Geo'. Survey Prof. Paper 173.

Girty, G. H., 1905, The relations of some Carboniferous faunas: Wash. Acad. Sci., Proc. v. 7, p. 1-26.

Hague, Arnold, 1883, Abstract of report on the geology of the Eureka district, Nevada: U. S. Geol. Survey 3d Ann. Rept., p. 237-272.

1892, Geology of the Eureka district, Nevada: U. S. Geol. Survey Mon. 20 (with an atlas).

Hazzard, J. C., 1937, Paleozoic section in the Norah and Resting Springs Mountains, Inyo County, Calif.: Calif. Jour. Mines and Geology, v. 33, p. 273-339.

Hewett, D. F., 1931, Geology and ore deposits of the Goodsprings quadrangle, Nevada: U. S. Geol. Survey Prof. Paper 162.

Hintze, F. F., 1949a, Devonian of Utah, in The $o^{* 1}$ and gas possibilities of Utah: Utah Geol. and Mineralog. S'rvey, p. 58-66. 1949b, Silurian of Utah, in The oil and gas possibilities of Utah: Utah Geol. and Mineralog. Survey, p. 55-57.

Hintze, L. F., 1949, Ordovician system of Utah, in The oil and gas possibilities of Utah: Utah Geol. and Mineralog. Survey, p. $38-54$.

- 1951, Lower Ordovician detailed stratigraphic sections for western Utah: Utah Geol. and Mineralog. Survey Bull. 39.

- 1952, Lower Ordovician trilobites from western Utah and eastern Nevada: Utah Geol. and Mineralog. Survey Bull. 48.

Hintze, L. F., and Webb, G. W., 1950, Ordovician stratigraphy from central Utah to central Nevada (ak ฯ.): Geol. Soc. America Bull., v. 61, p. 1524.

Humphrey, F. L., 1956 ?, Geology of the White Pine Range, White Pine County, Nev.: Nev. Univ. Bulletin, Geology and Mining series. (In preparation.)

Johnson, M. S., and Hibbard, D. E., 1956 ?, A geological survey of the Atomic Energy Commission Nevada P-oving Grounds area, Nye County, Nev.: U. S. Geol. Survey Bull. 1021-K. (In preparation.)

King, Clarence, 1878, Systematic geology: U. S. Geol. Expl. 40th Par. Rept. v. 1.

Kirk, Edwin, 1918, in Knopf, Adolph, A geolorical reconnaissance of the Inyo Range and the eastern slope of the southern Sierra Nevada, California: U. S. Geol. Survey Prof. Paper 110 , p. 19-48.

1927, New American occurrence of Stringocephalus: Am. Jour. Sci., 5th ser., v. 13, p. 219-222.

- 1933, The Eureka quartzite of the Gres.t Basin region: Am. Jour. Sci., 5th ser., v. 26, p. 27-44.

1934, The lower Ordovician El Paso limostone of Texas and its correlatives: Am. Jour. Sci., 5th ser., v. 28, p. 443463. 
Laird, W. M., 1947, An upper Devonian brachiopod fauna from northwestern Montana: Jour. Paleontology, v. 21, p. 453-459.

Lawson, A. C., 1906, The copper deposits of the Robinson mining district, Nevada: Calif. Univ., Dept. Geol. Bull. 4, p. 287-357.

Lindgren, Waldemar, and Loughlin, G. F., 1919, Geology and ore deposits of the Tintic mining district, Utah: U. S. Geol. Survey Prof. Paper 107.

Longwell, C. R., 1928, Geology of the Muddy Mountains, Nevada, with a section through the Virgin Range to the Grand Wash Cliffs, Arizona: U. S. Geol. Survey Bull. 798.

Longwell, C. R., and Dunbar, C. O., 1936, Problems of Pennsylvanian-Permian boundary in southern Nevada: Am. Assoc. Petroleum Geologists Bull., v. 20, p. 1198-1207.

McAllister, J. F., 1952, Rocks and structure of the Quartz Spring area, Northern Panamint Range, California: Calif. State Div. Mines Special Rept. 25.

MacNeil, F. S., 1939, Fresh-water invertebrates and land plants of Cretaceous age from Eureka, Nev.: Jour. Paleontology, v. 13, p. 355-360.

Mason, J. F., 1936, Cambrian faunas of the Goodsprings and Sheep Mountain districts, Nevada (abs.): Geol. Soc. America Proc. 1935, p. 384-385.

Merriam, C. W., 1940, Devonian stratigraphy and paleontology of the Roberts Mountains region, Nevada: Geol. Soc. America Special Paper 25.

1956, Paleozoic rocks of Antelope Valley, Eureka County, Nev.: U. S. Geol. Survey Prof. Paper. (In preparation.)

Merriam, C. W., and Anderson, C. A., 1942, Reconnaissance survey of the Roberts Mountains, Nev.: Geol. Soc. America Bull., v. 53, p. 1675-1728.

Miller, A. K., Downs, H. R., and Youngquist, W. L., 1949, Some Mississippian cephalopods from central and western United States: Jour. Paleontology, v. 23, p. 600-612.

Muller, S. W., Ferguson, H. G., and Roberts, R. J., 1951, Mount Tobin quadrangle, Nevada: U. S. Geol. Survey Geologic Quadrangle Map GQ-7.

Nolan, T. B., 1928, A late Paleozoic positive area in Nevada: Am. Jour. Sci., 5th ser., v. 16, p. 153-161.

1935, The Gold Hill mining district, Utah: U. S. Geol. Survey Prof. Paper 177.

1943, The Basin and Range province in Utah, Nevada, and California: U. S. Geol. Survey Prof. Paper 197-D, p. 141-196.

Palmer, A. R., 1954, An appraisal of the Great Basin Middle Cambrian trilobites described before 1900: U. S. Geol. Survey Prof. Paper 264-D, p. 55-86.

1955, Upper Cambrian agnostida from the Eureka district, Nevada: Jour. Paleontology, v. 28, no. 1, p. 86-101.

Pennebaker, E. N., 1932, Geology of the Robinson (Ely) mining district, in Nevada: Mining and Metallurgy, v. 13, p. 163168.

Resser, C. E., 1935, Nomenclature of some Cambrian trilobites: Smithsonian Misc. Coll. v. 93, no. 5.

- 1936, Second contribution to the nomenclature of Cambrian trilobites: Smithsonian Misc. Coll. v. 94, no. 4.

1937, Third contribution to the nomenclature of Cambrian trilobites: Smithsonian Misc. Coll. v. 95, no. 2.

Richardson, G. B., 1913, The Paleozoic section in northern Utah: Am. Jour. Sci., 4th ser., v. 36, p. 406-416.

Roberts, R. J., 1942, Manganese deposits in the Nevada district, White Pine County, Nev.: U. S. Geol. Survey Bull. 931-M, p. 295-318.
Roberts, R. J., 1951, Antler Peak quadrangle, Nevada: U. S. Geol. Survey Geologic Quadrangle Map GQ-10.

Ross, R. J., Jr., 1949, Stratigraphy and trilobite faunal zones of the Garden City formation, northeastern Utah: Am. Jour. Sci., v. 247, p. 472-491.

- 1951, Stratigraphy of the Garden City formation in northeastern Utah and its trilobite faunas: Peabody Mus. Nat. Hist., Bull. 6.

Schaller, W. T., and Glass, J. J., 1942, Occurrence of pink zoisite (thulite) in the United States: Am. Mineralogist, v. 27, p. 519-524.

Schuchert, Charles, 1923, Sites and nature of the North Arjerican geosynclines: Geol. Soc. America Bull., v. 34, p. 151--230.

Sharp, R. P., 1942, Stratigraphy and structure of the scithern Ruby Mountains, Nevada: Geol. Soc. America Bull., v. 53, p. 647-690.

Sharp, William, 1947, The story of Eureka: Am. Inst. Min. Eng. Tech. Pub. 2196.

Spencer, A. C., 1917, The geology and ore deposits of Ely, Nev.: U. S. Geol. Survey Prof. Paper 96.

Stumm, E. C., 1942, Fauna and stratigraphic relations of the Prout limestone and Plum Brook shale of northerr Ohio: Jour. Paleontology, v. 16, p. 549-563.

Walcott, C. D., 1884, Paleontology of the Eureka district: U. S. Geol. Survey Mon. 8.

- 1908a, Nomenclature of some Cambrian Cordilleran formations: Smithsonian Misc. Coll. v. 53, pub. no. 1804, p. 1-12.

- 1908b, Cambrian sections of the Cordilleran area: Smithsonian Misc. Coll. v. 53, pub. no. 1812, p. 166--230.

1923, Nomenclature of some post Cambrian anc Cambrian Cordilleran formations: Smithsonian Misc. Coll. v. 67 , no. 8 , p. 457-476.

Warren, P. S., 1942, The Spirifer argentarius fauna in the Canadian Rockies: Royal Soc. Canada Trans., 3d ser., v. 36, sec. 4, p. 129-136.

1944, The role of Sphaerospongia tessellata in the MacKenzie River Devonian: Canadian Field-Naturalist: v. 58, p. 28-29.

- 1949, Fossil zones of Devonian of Alberta: Am. Assoc. Petroleum Geologists Bull., v. 33, p. 564-571.

Warren, P. S., and Stelck, C. R., 1949, The late middle Devonian unconformity in northwestern Canada: Royal Soc. Canada Trans., 3d ser., v. 43, ssc. 4, p. 139-148.

Weller, J. M., and others, 1948, Correlation of the Missisippian formations of North America: Geol. Soc. Americs Bull., v. 59, p. 91-196.

Westgate, L. G., and Knopf, Adolph, 1932, Geology and ore deposits of the Pioche district, Nevada: U. S. Geol. Survey Prof. Paper 171.

Wheeler, H. E., 1940, Revisions in the Cambrian stratiwraphy of the Pioche district, Nevada: Nev. Univ. Bull., v. 34, no. 8, Geology and Mining ser. 34, p. 7-42.

Wheeler, H. E., 1948, Late pre-Cambrian-Cambrian stratigraphic cross section through southern Nevada: Nev. Univ. Bull., v. 42, no. 3, Geology and Mining ser., 47.

Wheeler, H. E., and Lemmon, D. M., 1939, Cambrian formations of the Eureka and Pioche districts, Nevada: Ner. Univ. Bull., v. 33, no. 3, Geology and Mining ser., 31.

Wheeler, H. E., and Steele, G., 1951, Geology of the Canyon House and Confusion Ranges, Millard County, Utah: Utah Geol. Soc. Guidebook 6, p. 35-36.

Youngquist, W. L., 1949, The cephalopod fauna of the White Pine shale of Nevada: Jour. Paleontology, v. 23, no. 3, p. 276-305; supplement, no. 6, p. 613-616. 



\section{INDEX}

A

A bstract .................................... 1-2

Acheilus sp., from Windfall formation......- 22

Acknowledgments............................ 3

aculeata, Syringopora, from Joana limestone_.- $\quad 56$

Adams Hill, Dunderburg shale exposed....... $\quad 18$

Hamburg dolomite exposed................. 16,17

Secret Canyon shale exposed near.......... 13,14

Windfall formation exposed............... 20

affinis Berkeia, from Dunderberg shale......-. 19

Agnostus sp., from Hamburg dolomite......-. 18

from Secret Canyon shale................... 16

Alhambra Hills, Devils Gate limestone exposed

Nevada formation exposed.... 41, 42, 43, 44, 45, 47

Alokistocare sp., from Secret Canyon shale.... 16 americana Bowmania, from Windfall formation

Amplexi-Zaphrentis sp., from Joana limestone. anceps, Obolus.

Ancyrodella cf. A curvata

Anderson, C. A., quoted...................... 34-36

angustifrons, Eurekia........................ 22

angustilimbata, Parairvingella................ 19

annectens, Desmetia

Anomalorthis lonensis......................... 29 nenadensis.

Anomalorthis fauna, correlated................

Anomalorthis zone, of Antelope Valley lime-

stone.

Antagmus sp

Antelope Range............. 5, 20, 21, 22, 27, 28, 31, 47

Antelope Valley ............................ 3, 21,

$24,25,27,28,29,30,31,32,33,34,36,37,38,39,67,69$

Antelope Valley limestone of Pogonip group,

age and correlation ...................... 28-29

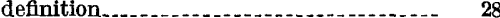

description

fossils...

relation to Vinini formation

antelopensis, Hesperonomia....................

(Antiquitonia) multistriatus, Dictyoclostus.....

Antler Peak quadrangle..........................

Apatokephaioides sp ...............................

Apatokephalus sp...............................

Apheoorthis melita

Archaeorthis elongata................................

arenosus, Spirifer.

argentarius, Spirifer

Asaphiscus laebiceps.

Asaphiscus sp

Ascopora . .

Athyris monticola

Atrypa

devoniana.

independensis.

montanensis

Atrypa Peak.

(n)

Avonia subhorrida................................. 68

B

barrandei, Pliomerops

Bathyuriscus sp.......................................

Bay State dolonite member of Nevada forma-

tion, correlation with Ruby Range section.

definition........................................ 45

deseription.

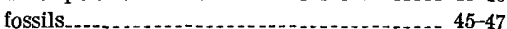

Page

Bay State mine

Beacon Peak........................ 43, 46

Beacon Peak member of Nevada formation,

correlation with Sevy dolomite definition.

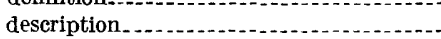

fossils.

belemnura, Xenostegium

Berkeia affinis

Bienvillia corax

Bighorn dolomite, correlation with Eureka quartzite. .

bilobata, Pterocephalina .......................

bisulcatum, Eumorphoceras..................

bivia, Leperditia.

$41,42,43,44,45,46,49,52,69$

blairi, Products

Blue Flaggy limestone...................... 11

Bluebird dolomite

Bluebird lithologic type of Hamburg dolomite. $\quad 16$

Bolaspidella spp............................. 16, 18

Bold Bluff

Bonnia laevigata........................... 8

Bowman fault

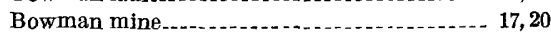

Bowmania americana....................... 22

Brachythyris................................ 51

Brachythyris sp................................ 60

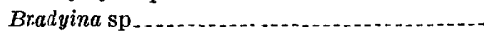

brevis, Geragnostus.

Bryantodus.................................... 53

Bullwhacker member of Windfall formation,

definition

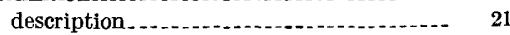

fossils

Bullwhacker mine, Bullwhacker member named from section at....................

Goodwin limestone exposed near.

sill intruded in section at................

Windfall formation mapped near

burlingi, Conodiscus......................... 22

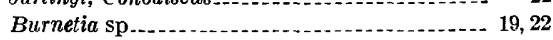

Buxtonia, cf. B. peruriana

\section{C}

calcaratus trifidus, Orthograptus.

Calvinella tenuisculpta.

Camarotoechia $\mathrm{sp.}$

Camerella sublaevis.

(Cancrinella) phosphaticus, Linoproductus

Caninophyllum sp.

carboniferum Leiorhynchus. ..................... Nudirostra........................ 61

Carbon Ridge......... 58,62,64,65

Carbon Ridge formation, age and correlation.- 65-67

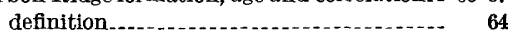
description. . . . .

fossils ............. 65-66

Caribou Hill, Eureka quartzite exposed. . . $\quad 29$ carinifera, Syntrophina.................... 27 carteri, Syringothyris ...................... 61

Caryocaris shale at Ninemile Canyon castanea, Leiorhynchus Castle Mountain, Eureka quartzite exposed
Page

Catlin member of Windfall formation, descrip-

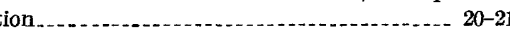

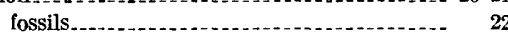
measured section ........................ 21

Catlin shaft of Croesus mine, Catlin merr her designated from....................

Cave Canyon, Pioche shale exposed ......... 8 Prospect Mountain quartzite exposed ... 6 Secret Canyon shale exposed.......... 13

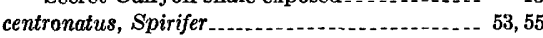

Chaetetes milleporaceus

Chainman shale, age and correlation........ 58-59 description. - . fossils 60

Chainman-Diamond Peak formations undifferentiated

Charter Tunnel, Geddes limestone exposed

near........................................... 12

Cheilocephalus sp ........................ 19

Cherry Spring

Chonetes loganensis ........................ 55 oklahomensis _................................. 60 sp

Chonetina

Cladopora . . . ...................... 44, 45, 47, 49, 50

Clarkella $\mathrm{sp}$

Clarks Spring.

Clarks Spring member of Secret Canyon shale,

age and correlation. . . . .

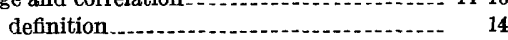

description................................... 14

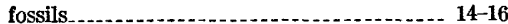

Cleiothyridinas....... 61,63

Climacammina $\mathrm{sp}$................................... 63

Climacograptus tridentatus maximums......... $\quad 33$

coloradoensis, Dictyoclostus ................... 63

Columnaria

Combs Peak . . ..................... 40, 43, 46

communis, Pseudagnostus .

compacta, Schwagerina._._._._._._....... 66

complanatus ornatus, Dicellograptus......... 33

Composita .............................. 55, 61, 66, 68

Conchidium sp.............................. 37

Conical Hill $\ldots \ldots \ldots$.

Conodiscus..................................... 22

burlingi.............. 22

convergens, Pseudagnostus_.................... 22

Cooper, G. A., quoted.

Copenhagen Canyon

corax, Bienvillia

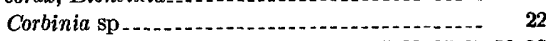

Cortez $\ldots \ldots \ldots \ldots \ldots . . . \ldots \ldots, 5,23,25,27,30,32$

Crassifimbria sp............................. 8

Cravenoceratoides.

Croesus mine........................... 20

Cryptolithus sp . .

curvata, Ancyrodella......................... 53

Cyathaxonia

Cyrtospirifer fauna............................ 48

Cyrtospirifer zone.............................. 51

D

Dale Canyon.................................. 57 Dalmanella........ Desmetia annectens........................... 22

Desmorthis_................................... 29 Devils Gate $\ldots . . . \ldots \ldots \ldots, 38,48,49.50,51,57$

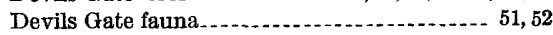


Page

Devils Gate limestone, age and correlation _.. 50-52 description................................. 48 fossils. . . .

Hayes Canyon member. .......... 49-50 Meister member........................ 49 devoniana, Atrypa

Diamond mine........................ 9,12, 14, 16, 20

Diamond Mountains .......................... 2, 38 $41,42,43,44,45,46,48,49,51,52,54,55,57,58$, $59,61,62,64,65,66,68,69$.

Diamond Peak ........... 38, 41, 49, 52,54, 55, 58, 61, 62 Diamond Peak fauna........................... 59,61 Diamond Peak formation, age and correlation. 58-59 description . . . 60

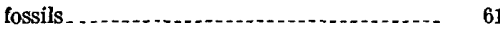
general features.......................... 56-59 Diamond Peak quartzite of Hague

Diamond Peak series of Merriam ......... Diamond Peak-Ely transition zone............ 63 Diamond Tunnel............................. 11

Diamond-Excelsior mine..................... 17

Diaphragmus

Dicellograptus complanatus ornatus

Dicoelosia

Dictyoclostus coloradoensis

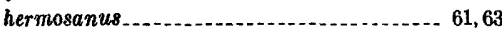
huecoensis................................ 66 ivesi portlockianus . . n. sp

Dictyoclostus (Antiquitonia) multistriatus.....- 66

Dimegelasma neglectum -................... 60 sp. 61

Diplagnostus sp.....-...-...- 12

Diplapatokephalus finalis

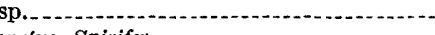

disjunctus, Spirifer

Disphyllum nevadense.

dissimilis Eurekia

Dokimocephalus pernasutus

Dorypyge sp

Dry Lake.

Duncan, Helen, quoted

Dunderberg shale, age and correlation ....... description. . . . .

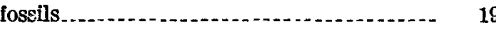
measured section

Dunderbergia granulosa. halli...

maculosa

nitida

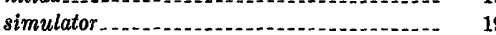

Dunderberg mine. ............................ 18, 20

Economic significance of Eureka area.........

Ectenonotus westoni

Eldoradia linarssoni............................. prospectensis.

Idorado dolomite, age and correlation

Eldorado Tunnel........................... 9

Elkania...................................... 22 hamburgensis............................. 22 Elkia nasuta.

elongata, Archaeorthis

elongatus, Receptaculites

Elrathia occidentalis

Elrathiella spp.

Elrathina spp.

Ely district....................................... 28

$29,34,39,51,52,53,54,55,56,59,61,63,64,66$

Ely limestone, age and correlation ............ 63 fossils.............................................. 63 general features............................. 61-63 measured section. ........................... 62 emmonsi, Hypothyridina

engelmanni, Spirifer.................................

Eumorphoceras bisulcatum

Euomphalus

Euptychaspis kirki...............................

Eureka mining district quadrangle...... 3, 20, 24, 25

Eureka quadrangle .............. 3, 43, 48, 52, 57, 58, 62

Eureka quartzite, age and correlation .......... 31-32 general features.......................... 29-31

Eureka Tunnel......................... 6, 11, 12, 13,14

eurekensis, Homotreta

Kootenia

Moorfieldella

Parairvingella

Ptychopleurites

Richardsonella

Symphysurina

Eurekia

angustifrons

dissimilis.

granulosa.

sp

expansus, Olenoides.

F

Faberophyllum

Fad shaft

Favosites limitaris

finalis, Diplapatokephalus

fremonti, Olenellus........................... 20, 32, 38,41

Frenchmans Flat_......................... 52

Frísco district, Utah

Fusulinella

\section{G}

Garden Valley

Garden Valley lormation, age and correlation. fossils........................................... 68

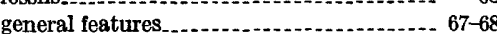

Garden Valley quadrangle................... 3,67

Geddes and Bertrand mine.

Geddes limestone, age and correlation...... 12 description................................... 112 fossils

Geragnostus brevis.............................. 22 tumidosus.................................. 19, 22

sp

giganteus, Productus.

Giganoproductus

Girvanella

Glyptagnostus reticulatus

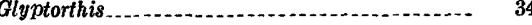

Glyptotrophia sp $\ldots$

Golconda, Nev., Antler Peak formation near $\quad 66$

Gold Hill district, Utab .... 11,31, 38, 47, 52, 53, 59, 63

Goldfield, Nev. .............................

Goniagnostus sp.............................. 12

Goodsprings, $\mathrm{Nev}$

Goodwin Canyon.......... 11, 12, 16, 20, 25, 26, 27, 28

Goodwin formation of Walcott _ _ 20, 24, 25

Goodwin limestone of the Pogonip group, age

and correlation.............................. 26-27 definition - .

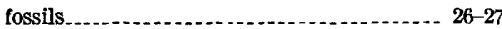
general features................. 25-26

Gordon, Mackenzie, Jr., quoted ............ 61

Gorman Hill . . . . . . . . . . 64, 65, 69 granulosa, Dunderbergia Eurekia.................................... 22

Grays Canyon

Great Basin ......1, 2, 3, 5, 6, 8, 9, 14, 23, 24, 25, 31, $32,34,37,40,47,50$

Great Slave Lake

Green Springs quadrangle .....................

Guilmette formation, correlation with Devils Gate limestone............................ 52 correlation with Nevada formation . . ..... 47-48
$\mathbf{H}$

Page

Hague, Arnold, quoted ................. 7, 38, 40 halli Dunderbergia . . . . . . . . . . . . . . . 19 Halysites . . . ............................ 34, 37, 38, 39 Hamburg dolomite, age and correlation...... 17-18 description.................. 16-17 fossils

Hamburg mine hamburgensis, Elkania........................ 22 Nanorthis.

Hamburg Ridge............................... 69

Hamilton, Nev .............................. 5,51

Hamilton district............... 23, 25, 28, 29, 56, 59

Hanson Creek formation, age and correlation - 33-34 definition ................................ fossils............................ 33-34 general features.............................. 32-33

Hass, W. H., quoted.

Hayes Canyon. ..................................... 49

Hayes Canyon member of Devi' Gate limestone, age and correlation................... 50-52 definition. - 49 description . $49-50$ fossils

Heliolites

Henbest, L. G., quoted............... 63, 65, 66, 68

hermosanus Dictyoclostus _.................... 61,63

Hesperonomia antelopensis_................. 27

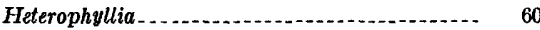

Heterorthis_._._.

Hibbardella................................. 53

Hindeodella 53

hirsuitiformis Productella

Holteria problematica

Homalophyllites sp.......................... 18, 55

Homoeospira ............................... 37

Homotreta eurekensis............................... 22 sp

Hoosac Mountain. .................... 29, 32, 33, 57, 64

Hope Greenstone.

Hornitos cone.......

Housia spp.

Howellella._................... 38,39

huencoensis Dictyoclostus..................... 66

Hungaia sp

Hunter's Ranch.

Hustedia meekana

Hypagnostus parvifrons

Hypothyridina emmonsi.

sp. a

Hystricurus sp............................... 27

Ibex, Utah

Icriodus

Iddingsia nevadensis

robusta

similis

Idiomesus sp.................................. 22

increbescens, Spirifer......... 61

independensis, Atrypa..................... 47

inflatus, Productus........................... 61

Introduction.

Inyo County, Calif.......................... 56

Inyo Range, Calif. ........................ 34, 37,

iole, Tostonia .............................. 22

iphis, Westonia.................. 22

irregularis, Triticites

Irvingella major ............................... 22

sp

Island Mountain................................ 55

ivesi, Dictyoclostus

Jackson fault

18

Jackson mine- 
Page

Joana limestone, age and correlation ........ 55-56 description. $54-55$ fossils. Juresania.............................. 66

Juresanias _..................... 63

\section{K}

Kainella ................................... 22,27

Kainella fauna

Kinbladia sp............. 22

Kindaijia sp........... 60

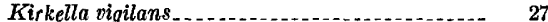

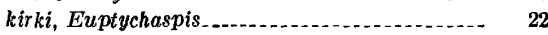
Martinia

kobehana, Spirifer _ 46,48

Koninckophyllum sp.................... 56

Kootenia eurekensis.

Kormagnostus seclusus......... 18

\section{$\mathbf{L}$}

laevigata, Bonnia

laevis, Pseudagnostus

Leiocoryphe platycephala..............

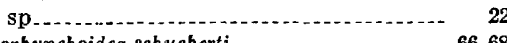

Leiorhynchoidea schucherti_................. 66, 68

Leiorhynchus carboniferum _._._._._._._. 61 castanea.................. 47

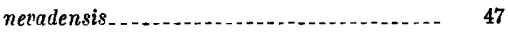

Leiostegium sp........................... 27

Leperditia $\ldots$ bivia....

Lepidocyclus.

Leptostrophia sp.

Ligonodina. . ...................... 53

limitaris, Fanosites

linarssoni, Eldoradia..................... 16

linearis, Schwagerina...................... 68

lineata, Parafusulina

Linguella sp........................ 22, 26, 27

linguiformis Polygnathus ................... 53

Lingula $\ldots \ldots \ldots$

Linoproductus............ 66 ovatus . . ................................... 60, 61

Linoproductus (Cancrinella) phosphaticus _..- 66

Litocephalus richmondensis.................. 19, 22

Lithostrotionella $\mathrm{n} . \mathrm{sp} \ldots \ldots \ldots$

Litocephalus rich mondensis.............. 19,22

Locan shaft. . . . . . .

loganensis, Chonetes

Lone Mountain. ..... 3, 29, 30, 31, 32, 33, 34, 36, 37, 38, $39,41,42,43,44,45,46,47,48,49$

Lone Mountain dolomite, age and correlation - 39-40 fossils . . . . . . . . . . . . general features.......... $37-39$

Lone Mountain formation, restricted, of Mer-

riam

Lone Mountain limestone of Hague _. _.... 23, 32, 36

longwelli, Mitrospira Orthidiella

Lotagnostus obscurus

Lower Coal Measures of Hague _ _ . 54, 60, 62, 64, 68, 69

Lower Prospect Mountain limestone

Lower shale member of Secret Canyon shale,

age and correlation . . .................. 14-16

description . . . .

fossils

\section{M}

McCoy Ridge................... 25, 28, 29, 30, 32, 33 mccoyi, Orecopia ...... 51 Platyschisma

Macgeea - 51 subcylindrica Maclurites

MacNeil, F. S., quoted.................... 70 maculosa, Dunderbergia Madison fauna.

Mahogany Hills. $41,45,46,47,48,49$
Page

roingella

mammillaris, Receptaculites...................

marcoui infraplicatus, Spirifer

Marginifera.

marica, Tellerina

Martinia kirki

nevadensis.

Martins Ridge

maximums, Climacograptus tridentatus . . .....

meekana, Hustedia

Meekella

Meister limestone member of Devils Gate

limestone, age and correlation. . . ......... 50-52

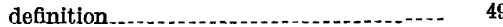

description.......................... 49

fossils..... $50-52$

Meister mine

melita, Apheoorthis.

Mercury Test Site

Merriam, C. W., quoted . . . . . . . 30, 33, 34-36, 44

Mictophyllum

milleporaceous, Chaetetes.................... 63

Millerella................................ 63 pingus - 63

Mineral Hill ............... 9, 10, 11, 12,13,14, 16, 17

Mineral Hill quadrangle........ 3

Mining Canyon

missouriensis, Shumardella

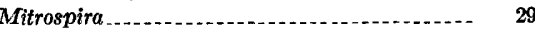

longuelli............... 29

Modoc Peak................. 40, 42, 43, 45, 46. 47, 49

Modocia nenatensis. . . . . . . . . . . . . . . . 16,18

Monitor Range

Monograptus........................... 37

montanen sis, Atrypa

monticola, Athyris.......................... 55

Moorfieldella eurekensis..._._._._._. 61

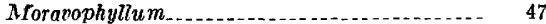

Morrow formation, relation to Ely limestone _. $\quad 63$

mortonanus, Spirifer.... 60

Mount Hamilton............................ 23

Mount Hope.......... 30, 34

Mount Hope mine.

Mount Lewis............... 6

Mount Tobin qradrangle.

Mountain shale, according to Hague-....... $\quad 7,9$

Muddy Mountains.

multicostata, Nanorthis..................... 27

multistriatus, Dictyoclostus (Antiquitonia) ..... 66

\section{$\mathrm{N}$}

Nanorthis hamburgensis................... 26, 27 multi rostata............................ 27

nasuta, Elkiq............. 22

negle $t u m$, Dimegelasma

Neospirifer.... 66

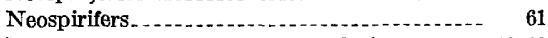

Nevada formation, age and correlation. ...... 46-48 Bay State dolomite member Beacon Peak dolomite member......... 42 description. . ........ $40-42$

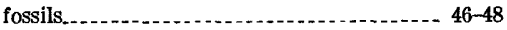

Oxyoke Canyon sandstone member...... 43 Sentinel Mountain dolomite member ..... 43-44 Woodpecker limestone member........... 44-45

Nevada limestone, of Hague . . . . . . . .... 37, 40, 48 of Spencer............................ 39,51 nevadense, Disphyllum ................ 50 nevadensis, Anomalorthis............... 29

Briscoia. . . ........ 22

Iddingsia $\ldots$

leiorhynchus.

Martinia

Modocia

Paedumias

Pliomerops

Rhipidomella

New Windfall shaft. $\ldots \ldots \ldots, 21$

New York Canyon....... 13, 14, 16, 18, 20, 32, 33, 65

Newark Canyon................................ 70
Newark Canyon formation, age and correlation -.- 70 fossils............. 70 general features......................... 68-70

Newark Canyon Road ............. 64, 65, 66, 69, 70

Newark Mountain ....................... 40 ,

$41,43,44,45,46,47,48,49,50,52,5557,58,59$

Newark Summit. . . . . .

Newark Valley............................... 48,62

Newberrya.

Ninemile Canyon . . . . ....... 20, 21, 22, 23, 24, 26, 27

Ninemile formation of Pogonip group, age and

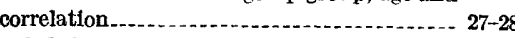

definition.......................................... 27

equivalence to Vinini formation . . . . ... 36

fossils . ................................... 27

general features................................ 27

nitida, Dunderbergia ...................... 19

Nopah Range. . . . . . . . . . .

nosonensis, Parafusulina

Nothognathella..................................

Nudirostra carboniferum

26

anceps

obscurus, Lotagnostus _................ 22

occidens, Pterocephalia ................... 19

occidentalis, Elrathia .................... 12

ohioensis, Triticites

oklahomensis, Chonetes

Olenellus........ 8

fremonti............... 8

Olenellus shale, according to Hague

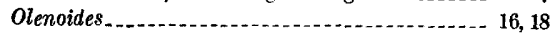

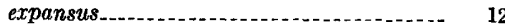

pugio

Onchocephalus parvus.................. 8

Orecopia mccoyi................... 51

Orria sp.

Orthidiella longwelli..............

striata...................................... 29

Orthidiella zone.......... 28

Orthis sp...................

Orthograptus calcaratus trifidus _.............. 33

sp_...... 33

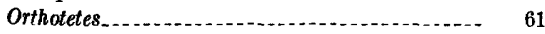

oryziformis, Triticites. 65

Osgood Mountain

Oswego mine

Oxyoke Canyon....... 38, 39, 40, 42, 43, 44, 45, 46, 47

Oxyoke Canyon sandstone member of Nerada formation, age and correlation.... 46-48 definition...-. description. -

$\mathbf{P}$

Packer Basin_._. .

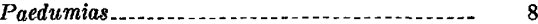
nevadensis. . . . 8

Palmer, A. R., quoted........... 8, 12, 16, 18, 19, 22

Palmatolepis subreta $\ldots \ldots . . . . . . . . . . . . .53$

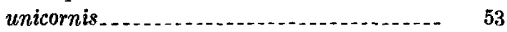

n. sp. A .

n. sp. B .

Pancake Range_....................... 52, 54, 55

Pancake Summit quadrangle............ 23

Parabolinella ........ 19,22

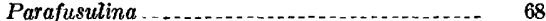

lineata

nosonensis.................. 68

Parafusulina zone............ 66

Parairvingella angustilimbata............... $\quad 19$ eurekensis............ 19 sp

parvifrons, Hypagnostus

parvus, Onchocephalus................... 8

Peachella iddingsi

pennata, Polygnathus....................... 53 


\begin{tabular}{|c|c|c|}
\hline \multicolumn{2}{|c|}{ Page } & Pag \\
\hline Periomma sp. & 8 & Ptychagnostus (Ptychagnostus) richmondensis.. \\
\hline pernasutus, Dokimocephalus. & 19 & (Triplagnostus) sp \\
\hline peroccidens, Proetus........... & 55 & (Ptychagnostus) richmondensis, Ptychagnostus. \\
\hline Peronopsis & 12 & Ptychopleurites eurekensis. \\
\hline perwviana, Buxtonia & 66 & pugio, Olenoides \\
\hline Pete Hanson Creek & 32 & Pugnoides. \\
\hline Phillipsastraea fauna & 51 & Punctolira punctolira \\
\hline Phillipsastraea zone & 51 & Punctospirifer \\
\hline Phillipsburg mine & & pustulosa, Rhynchopora \\
\hline
\end{tabular}

$41,42,43,44,45,46,48,49,52,55$
Phillipsia phosphaticus, Linoproductus (Cancrinella) .... 66

Pilot shale, age and correlation ........... 52-53 description........... 52 fossils $\ldots \ldots$ pingus, Millerella......... 63 Pinto Basin............ 69, 70 Pinto Creek Ranch. . . . . . $54,57,61,62,69$ Pinto Summit.................... 38 Pinto Summit quadrangle_........ 3, 48,52, 54, 55 pinyonensis, Spirifer-.......... 46

Pioche, Nev ................ 8, 11, 51, 63

Pioche district .............. 7, 11, 28

Pioche shale, age and correlation .......... 8-9

fossils............... 8

general features

Plaesiomys............ 33, 34

platycephala, Leiocoryphe..... 22

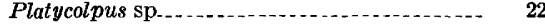

Platyschisma mecoyi............. 51

Platystrophia

Plectotrophia sp........ 26

$\begin{array}{ll}\text { Plethometopus sp } & 22 \\ \text { plicatulus, Triticites }\end{array}$

Pliomerops barrandei...... 29

nevadensis

sp.

Pogonip group, age and correlation ....... 25

Antelope Valley limestone............ 28-29

general features................. 24-25

Goodwin limestone.

Ninemile formation ................... 27-28

of Hintze....................... 24

Pogonip Ridge.

Polygnathus_................. 53

linguiformis. . .

pennata................. 53

Polypora.

portlockianus, Dictyoclostus_............... 63

Pre-Fusulinella bearing beds of Girty ......... $\quad 63$

Prioniodus.......... $\quad 53$

Prismatophyllum.....

$\begin{array}{ll}\text { problematica, Holteria } & 18 \\ \text { Productella cf. } P \text {. hirsuitiformis } & 61\end{array}$

Productus.

blairi_............. 55

giganteus............. 61

inflatus.

Proetus peroccidens

prolongus, Pseudagnostus.................. 22

Prospect Mountain limestone of Hague ..... $\quad 7,9$

Prospect Mountain quartzite, age and corre-

lation general features............ 6-7

Prospect Mountain Tunnel-_._. 7, 8, 9, 11, 12, 13, 14

Prospect Peak........ 6, 7, 8, 12, 16, 25, 27, 28, 29, 30.32

Prospect Ridge $\ldots \ldots \ldots \ldots$ $8,9,11,12,13,14,16,18,20,24,32,43$

prospectensis, Eldoradia.................. 16

Protowentzelella

Pseudagnostus communis

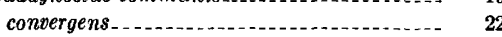

laevis.................... 22

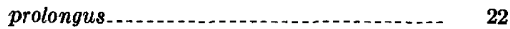

Pseudoschwagerina

Pseudostaffella....... 63

Pterocephalia occidens ..................... 19

sanctisabat $e_{\ldots} \ldots \ldots$

Pterocephalina bilobata..... 19

\section{Q}

Quartz Spring area, in California .... 29, 39, 46, 48, 52

\section{$\mathbf{R}$}

Rafinesquina sp............... 33

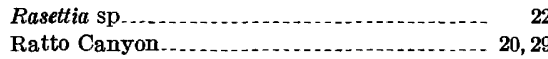

mammillaris.

Receptaculites facies. ................. 29

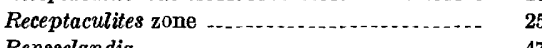

Rensselandia ................................ 47

Resting Springs Range.................... 38

reticulatus, clyptagnostus.

Rhabdomeson. .......... 66

Rhipidomellas -.... 63

Rhipidomella nevadensis.................. 60,61

Rhombotrypella. ... 63,66

Rhopalolasma sp..................... 60

Rhynchopora pustulosa

sp.

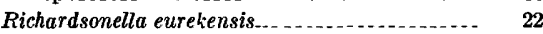

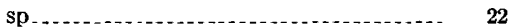

Richmond-Eureka mine . . $7,8,10,11,14,16,17,18,19$

Richmond Mountain_.......... 64,69

Richmond shaft....................... 14, 19

rich mondensis, Litocephalus. ................. 19,22

richmondensis, Ptychagnostus (Ptychagnostus)_ $\quad 12$

Roberts Creek Mountain._. 25, 28, 30, 31, 32, 34,

$36,37,38,39,41,42,43,44$

Roberts Mountains...... 23, 27, 30, 33, 34, 36, 45, 46, 47

Roberts Mountains formation, age and correla

tion fossils general features.......... $36-37$

Roberts M juntains thrust_......... 1, 54, 57,62, 67, 68

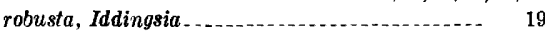
roemeri, Elvinia Roundtop Mountain Rowia sp.............. 18 Ruby Hill ......... 6, 7, 9, 10, 11, 12,14, 16, 17, 18 Ruby Hill fault . . . . ......... I1 Ruby Range ...... 5, 25, 28, 29, 31, 34, 39, 48, 51, 59, 66 Rylstonia teres. ................. 55

\section{$\mathrm{S}$}

sanctisabae, Pterocephalia 19,22 Saukiella sp.... Schizambon typicalis..... 27 Schizophoria ................... 47,51,61,63 Schubertella.................................... 66 Schuchertella_..... 55 schucherti, Leiorhynchoidea

Schwagerina compacta linearis

seclusus, Kormagnostus.................. 18

Secret Canyon........ 9, 12, 13, 14, 16, 17, 18, 19 $20,25,27,28,29,57,58,59,60,64,65,69$

Secret Canyon shale, age and correlation..... 14-16 Clarks Spring member. ...... 14 description . . . . $12-13$ fossils

lower shale member. . . . . . . . . . . . . . . 13-14

Sentinel Mountain dolomite member of

Nevada formation, age and correlation..... 46-48

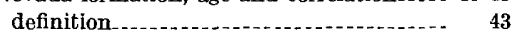
description. $43-44$
Receptaculites elongatus ......................

Sentinel Mountain . ......................... 43,44
Page

Septopora

Shadow Canyon............ 16, 18

Shumardella cf. S. missouriensis.

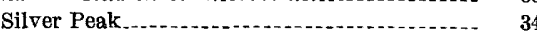

Silverado Mountain $\ldots . . . . . . . . . . . . .41,42,43,50,54$ similis, Iddingsia............... 19, 22 simulator, Dunderbergia Solenopleurella sp

South Gate spicata, Symphysurina spinosus, Zacanthoides..................... 12

Spirifer

arenosus.............. 46, 48

argentarius

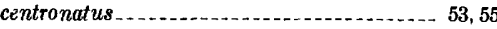

disjunctus_................................. 48

engelmanni.......... 51

increbescens............................... 61

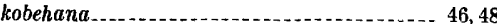

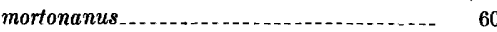

marcoui infraplicatus.................... 66

Spirifer argentarius zone.................. 50,51

Spirifer pinyonensis zone................... 46

Spring Mountains.................... 48, 63

Spring Ridge....................... 64,66

Spring Valley $\ldots . \ldots \ldots \ldots \ldots \ldots, 27,36,38,41$

Spring Valley fault................

striata, Orthidizlla

Stringocephalus ...................... 44, 45, 46, 47, 48

Stringocephalus fauna...................... 47, 48

Stringocephalus zone...................... 47

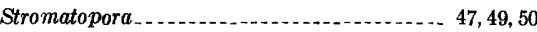

Strombodes

Structural setting

Styliolina type of pteropods

subcylindrica, Macgeea $\ldots . . . . . . . . . . . . . . .5$

subhorrida, Avonia

sublaevis, Camerella................... 27

subrecta, Palmatolepis

Sulphur Springs Range..... 34, 3₹ 41, 43, 45, 46, 48, 67

Summit Springs well ...._................. 65

surcularia, Syringopora............... 55,56

Surprise Peak............................. 20

Symphysurina

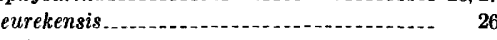

spicata

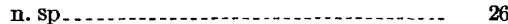

Syntrophina carinifera.................... 27

Syringopora

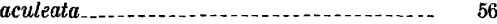

surcularia........... 55,56

Syringothyris carteri........ 61

$\mathbf{T}$

Table Mountain

Tabulophyllum

Tatonaspis sp.

Tellerina marica

Tenticospirifer utahensis

tenuisculpta, Calvinella

teres, Rylstonia

Tetralobula sp.

Thaerodonta

Thamnopora

Thammopora type of favositid

Tintic, Utah.

Toiyabe Range..................

Tollhouse Canyon .... 49, 52, 54, 55, 57, 58, 59, 60, 62, 69

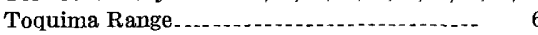

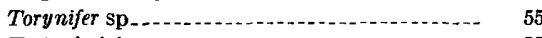

Tostonia iole....................... 22

Trematospira zone.......................... 46

tridentatus maximums, Climacograptus....... $\quad 33$

Trinucleus of Hague

(Triplagnostus) sp., Ptychagnostue........... $\quad 12$

Triticites....... 65,68

irregularis. . . .

ohioensis_........... 65

oryziformis

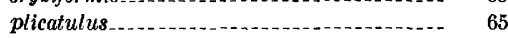

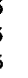

\section{(15)} 51 22

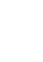

.

(n)


Page

tumidosus, Geragnostus

Tylonautilus sp...._._._._._.............. 61

Tylothyris . ......... 50

Tylothyris zone............................... 51

typicalis, Schizambon

Tyrone Gap......................... 62, 66, 67, 68

$\mathrm{U}$

Ufimia sp . . . .

unicornis, Palmatolepis..................... 53

Upper Coal Measures of Hague ........... 64, 65, 69

utahensis, Tentıcospirifer

\section{V}

Vesiculophyllum sp _..._.

vigilans, Kirkella_a

Vinini Creek .................................. 34

Vinini formation, description .............. 34-36

Water Canyon.
Page

Weber conglomerate of Hague........ 54,68, 70

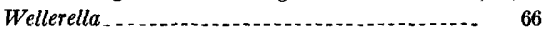

Western Peak .................. 30

westoni, Ectenonotus ...................... 29

Westonia

iphis_............

Whistler Mountain ........................ 34

White Mountain ........................ 25, 29, 32

White Pine mining district........... 24, 25, 54, 56

White Pine shale of Hague. 2, 40, 52, 54, 56, 57, 58, 59, 61

White Rock Canyon . .

Windfall Canyon.... 13, 14, 16, 17, 19, 20, 21, 22, 25, 26, $27,28,29,57,58,59,60,61$

Wind fall formation, age and correlation ...... 22-23 Bullwhacker member. . . . . . . . . . . . 21-22

Catlin member...... 20-21

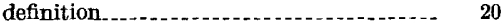

description. ......................... 19-20

fossils .......................................... 22-23

Windfall mill............................... 19

Windfall mine
Page

Windfall shaft

Wood Cone _. _ 20, 25, 27, 28, 31, 32, 33, 36, 37, 38, 39, 40

Woodpecker limestone member of Nevada

formation, age and correlation ........... 46-48 definition.......................... 44

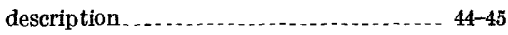

Woodpeckers Peak . . ................ 40, 41, 44, 45, 49

$\mathbf{X}$

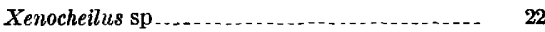

Xenorthis n. sp ............................ 22

Xenostegium belemnura

Y

Yahoo Canyon............................. 34, 51

Z

7acanthoides spinosus.................... $\quad 12$

Zulu Canyon........................... 13

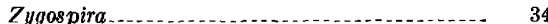


, 